\title{
Geochemical methods to infer landscape response to Quaternary climate change and land use in depositional archives: a review
}

Alexander Francke1,2*, Jens Holtvoeth ${ }^{3}$, Alexandru Codilean ${ }^{1,2,4}$, Jack H. Lacey ${ }^{5}$, Germain Bayon $^{6}$, and Anthony Dosseto ${ }^{1,2,4}$

*corresponding author

${ }^{1}$ Wollongong Isotope Geochronology Laboratory, School o Farth, Atmospheric and Life Sciences, University of Wollongong, Wollongong, NSW, Aur, w via

${ }^{2}$ GeoQuEST Research Centre, School of Earth, Atmosp' ${ }^{\prime}{ }^{\circ}:$, and Life Science, University of Wollongong, Wollongong, NSW, Australia

${ }^{3}$ School of Earth Sciences, University of Bristol, Bristol, United Kingdom

${ }^{4} \mathrm{ARC}$ Centre of Excellence for Australian Biodive. sity and Heritage (CABAH), University of Wollongong, Wollongong, NSW, Australia

${ }^{5}$ National Environmental Isotope Facil cy, 3rilish Geological Survey, Nottingham, United Kingdom

6IFREMER, Marine Geosciences Unะ, Bı `st, France 


\section{Abstract}

Understanding and quantifying the processes and geochemical cycles associated with catchment erosion, the development of soils and weathering horizons, and terrestrial habitat change beyond the scales of modern observations remain challenging. Such research, however, has become increasingly important to help predict future landscape change in light of increasing land use and rapid global warming. We herein review organic and inorganic geochemical tools applied to depositional archives to better understand various aspects of landscape evolution on geological time scales. We highlight the potentials and limitations of inorganic geo hemical analytical methods, such as major element geochemistry, metal and radiug 'nic isotopes, and in-situ cosmogenic nuclides, as qualitative, semi-quantitative a. 1 quantitative proxies for the transformation of bedrock material via regolith and sois to sediments. We also show how stable isotope geochemistry applied to lacus ${ }^{+}$ine endogenic carbonates can be used to infer rock-water interactions, vegetation change, and soil development in limestonerich catchments. Proxies focusing on the $s_{1}^{\prime} \cdot r^{\prime}$ astic element of sediment formation, transport and deposition are also idea'^y c smbined with organic geochemical proxies for vegetation change and soil organic mitter evolution in a catchment to gain a comprehensive picture of the $\mathrm{Cr}_{*}^{\cdot-\mathrm{c}} \mathrm{ca}$ i Zone's evolution over time. Multi-proxy and multidisciplinary research com.ann organic and inorganic geochemical techniques from several sedimentary arr iiv s in the same catchment have high potential to provide comprehensive information \&n Quaternary landscape evolution and thus improve the robustness of associate 1 tc recasting models.

\section{Keywords}

Quaternary landscape evolution, catchment erosion, terrestrial habitat change, land use, fluvial, lacustrine, inorganic geochemistry, organic geochemistry, radiogenic isotopes, metal isotopes, uranium isotopes, cosmogenic nuclides 


\section{Highlights}

\section{Introduction}

Geochemical and physical processes forming and modifying the landscape by weathering and erosion play an essential role in controlling atmospheric greenhouse gas concentrations on geological time scales (e.g. Berner 1994). Silicate weathering and carbonate deposition controls the fixation of atmospheric $\mathrm{CO}_{2}$ in marine sediments (e.g. Gaillardet et al. 1999; Kump et al. 2000). Large tropical and boreal forests as well as permafrost landscapes play a crucial role in biologic greent ouse gas drawdown from the atmosphere. Simultaneously, landscape evolution de cuds strongly on climate, vegetation, tectonic uplift, and, since the expansisn $v_{1}$ human settlements and technological advancements, on land use (e.g. C.ge ge et al. 2015; Marston 2010; Dotterweich 2008). In the light of anthropogenir clin ate warming and increasing land use, soils, one of our most important but finite resources, are expected to experience considerable modifications in the near futu* $\epsilon$. ${ }^{\mathrm{I}} \mathrm{Ir}$ to $65 \%$ of ice-free areas are predicted to be directly affected by climate cha ige which increases to $80 \%$ when the impact of human land use is considered (Ostberg t al. 2018). Deforestation of large forest areas (boreal and tropical) and subs=rutat accelerated erosion, but also thawing of permafrost landscapes, are frea $\cdots$ on. an irreversible loss of (biogenic) atmospheric $\mathrm{CO}_{2}$ sinks. The destruction of sucit la. dscapes has consequently been identified as a climate tipping point, i.e. a process t. at can lead to irreversible warming of the climate system (Lenton et al. 2019).

Studying Quaternary indscapes and (geochemical) processes in the Earth's Critical Zone, (i.e. the near-surface environment, where interactions between rock, soil, air, water, and biota determine the availability of nearly every life-sustaining resource, National Research Council 2001), can help us better understand landscape responses to climate forcing and land use on centennial to millennial time scales where modern observations are not possible. Only geological archives can provide records of long-term trends and/or tipping points of the landscape response and Critical Zone evolution to climate or anthropogenic forcing. Crossing tipping points in landscape evolution can have significant implications for the preservation of soil resources across the globe. This is probably best illustrated by findings from the Balkan Peninsula, where two studies on lake sediment cores have demonstrated that natural and anthropogenic vegetation 
changes have controlled threshold-like responses in catchment-wide erosion processes, leaving their trace in the landscape for several millennia (Francke et al. 2019; Rothacker et al. 2018). The study of Quaternary archives has also shown that it may take millennia for landscapes to recover from major modifications (e.g. Holtvoeth et al. 2017), and that anthropogenic changes can make the Critical Zone more sensitive to climate oscillations (Regattieri et al. 2019). Evidence for extensive land use for over two millennia is widespread in Europe, and in particular in the Mediterranean region (Dotterweich 2008). Understanding underlying geochemical cycles and processes is thus crucial for the mitigation of, and adaption to, threshold-like modifications of the Critical Zone. This also applies to parts of the world where substantial human 1 npact could be of shorter duration but higher severity due to technical advanı $m$.nts since the advent of agriculture practises (Dotterweich 2013).

Quantitative modern measurements and mode...in. of of sediment mobilisation and storage are of high importance for understanding soil erosion (see for example the special issue summarised in Panagos and Ka sr y: annis 2019). Measurements of present day erosion rates provide spatially a'as te mporally highly-resolved data but do not provide insights into the Critical Zc e's evolution under unprecedented climate conditions, such rapid climate warming of $>2^{\circ} \mathrm{C}$ as predicted for the near future (IPCC 2014). The amplitude of the lancs al e's response to such dramatic modifications can only be approximated in gec.'ngical archives spanning glacial-interglacial transitions (e.g. termination 1 - Last G' Cla' $^{\prime}$ to Holocene transition; termination 2), and by applying suitable geochemical mot, $\wedge s$, such as those reviewed herein. Research into the landscape's responst to $1 \mathrm{k}$ warm climate conditions (i.e. similar to those predicted for the next century) is al $\sim$ required. This can be achieved by focusing on past periods with climate conditions similar to the predicted climate conditions, such as MIS5e (marine isotope stage 5e, Eemian), MIS11c and MIS19 (Yin and Berger 2015). Research on Quaternary landscape evolution is thus essential to accurately predict the terrestrial response to a changing future climate, and provide crucial data for the implementation of local, regional, and global (such as IPCC, Intergovernmental Panel on Climate Change) landscape management plans.

Research on Quaternary landscape and Critical Zone evolution usually focuses on depositional archives, such as colluvial deposits, alluvial fans, river (fluvial) sediments, and lacustrine archives, and aims to provide insights into hillslope erosion, land-use impact, and climate change (Dotterweich 2013). Lithological analyses and chronological 
work is applied to detect the timing and characteristics of agricultural activity-induced hillslope erosion causing the deposition of colluvium at the footsteps of slopes, enhanced riverbed activity, sediment load transportation, and total sediment flux in a given catchment (e.g. Dotterweich 2008, 2013; Dreibrodt et al. 2010; James 2013). With the advent of novel (bio-)geochemical analytical methods and tools, research on Quaternary landscape evolution now focuses on more quantitative approaches in estimating catchment-wide erosion rates, and on the understanding of (bio-)geochemical cycles and terrestrial habitat change controlled by climate parameters (temperature, amount and seasonality of rainfall) and land use.

Here, we review a variety of new tools to decipher Quatern. ry landscape and Critical Zone evolution from detrital and non-detrital sedimenta. $?_{2}$ chives using geochemical and biogeochemical methods, and discuss the por ntisl and limitations of these methods. The techniques presented encor.puss high-resolution geochemical characterisation of continuous to semi-continuo's sedimentary archives, using X-ray fluorescence (XRF) core scanning, non-metal $(r, 2, N)$ and metal $(\mathrm{U}, \mathrm{Hf}, \mathrm{Nd}, \mathrm{Pb})$ isotope geochemistry, cosmogenic nuclides, an ${ }_{i}$ 'ip.' ${ }^{\top}$ biomarker analysis, (Fig. 1, Table 1). The review is intended to assist the reader 1 selecting the appropriate analytical methods

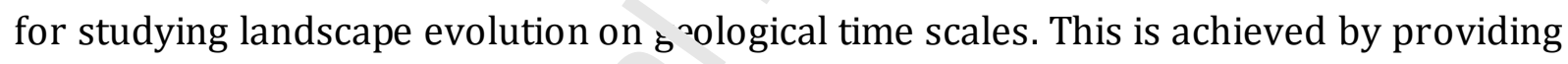
a comprehensive overview of the ro ential and limitations of geochemical methods in Quaternary research. The sele tion of the appropriate analytical method depends not only on the type of the depc sitı nal archive (e.g. fluvial, lacustrine) at the study site (Fig. 1, Table 2), but also on the chracteristics of the sedimentary archive (such as grain size, mineralogy, sedimes ${ }^{+}$-m.position) and of the catchment (such as bedrock geology, topology).

Fig. 1: Depositional archives and analytical techniques discussed in this review.

\section{Sediment chronology and accumulation}

The simplest methods to evaluate hillslope erosion in a catchment are qualitative, semiquantitative, and quantitative assessments on the timing and amount of detrital matter deposition in colluvial, alluvial fans, fluvial and lacustrine deposits (Fig. 1). Colluvial sediments being deposited at foothills of slopes with open vegetation and bare soils (Dreibrodt et al. 2010), alluvial fan deposits as product of gullying evolving upslope (Valentin et al. 2005), and modern and palaeo-fluvial sediments can provide insights 
into detrital matter mobility (erosion and river activity) in a given catchment by combining detailed structural and textural investigations with precise chronological work. Chronological information can be inferred from radiocarbon dating (of charcoal, plant remains, pottery artefacts), luminescence dating (of buried medium-sized sediment grains), or archaeological age estimation (Dreibrodt et al. 2010). In particular, colluvial and fluvial deposits benefit from the direct proximity to, and connectivity with, hillslopes and provide a high spatial resolution. However, such records are frequently discontinuous temporally, and occasionally destroyed by ploughing (Dreibrodt et al. 2010). The quality of information on hillslope erosion, as determined from riverbed activity and sediment flux estimates derived from dating oi fluvial deposits, depends strongly on site-specific factors, i.e. the connectivity of th la idscape and complexity of catchment morphology (Baartman et al. 2013). The sa. $\vee^{1}$ mitations apply for estimates of catchment erosion as derived from detrital mat.c. sediment yields (in t $/ \mathrm{km}^{2} / \mathrm{yr}$ ) to a lacustrine basin. Lake sediments, however, he ofit from the more continuous, temporally-highly-resolved information pro ir.e l. For lake basins, the detrital matter sediment yield is difficult to assess sins _ ' $7 c_{\text {. }}$ strine sediments are typically composed of a complex mixture of authigenic (such is organic matter or carbonate minerals) and allogenic (detrital matter) componen ‘ ‘. Zolitschka (1998) modelled total sediment yield using chronological, physical, and ('jic -)geochemical proxy analyses to account for nondetrital matter in bulk lacustri, e sediment compositions. Firstly, a robust chronology is used to calculate sedimenta ${ }^{4} \mathrm{ol}_{1}$, rates over time (cm/yr). Physical (density in $\mathrm{g} / \mathrm{cm}^{3}$ ) and geochemical analyses ( ${ }^{\prime \prime} c_{1}$. is inorganic and organic carbon contents, biogenic silica contents) of the sed ${ }_{1 .}$ e $_{1}{ }^{+}+$, nen allow total sediment accumulation rates to be estimated, as well as individual a $\cdots$ mulation rates for organic matter, authigenic/endogenic calcite and biogenic diatoms (mainly diatoms frustules and sponge needles). The detrital matter accumulation rate is then derived from subtracting modelled accumulation rates for non-detrital matter from the total sediment accumulation rate (Zolitschka 1998). Finally, the total sediment yield to the lake can be calculated by normalizing the detrital matter accumulation rate to the catchment size. Estimated sediment yields can be biased by direct aeolian deposition in the lake (resulting in over-estimation), loss of finegrained detrital matter via outflowing streams (under-estimation), shoreline erosion and mobilisation of lacustrine material by wave action (over-estimation), trapping of coarser material in delta systems (under-estimation), and sediment redistribution in the lake by wind-induced currents and contourite drift (e.g. Martin-Puertas et al. 2012; 
Zolitschka 1998; Wennrich et al. 2013; Vogel et al. 2010b). Incomplete supply of detrital matter to the lake and loss of material through outflowing streams can be estimated semi-quantitatively but can vary significantly in different landscapes and over time. Further uncertainties on derived sediment accumulation rates depend on the accuracy of the age-depth relationship in the archive. The chronology of Zolitschka (1998) was based on varve counting, i.e. the number of annually deposited layers in the lake. Varved layers, however, are not available in all sedimentary archives. Age-tie points, for example as derived from tephrochronology and/or radiocarbon dating at low resolution (e.g. Vogel et al. 2010c), might introduce uncertainties to modelled accumulation rates if distributed unevenly across the analysed sequence. This issu can partly be addressed by considering the sediment's lithological features and by "s'ing a robust, Bayesian agedepth modelling approach (Blaauw et al. 2018). Altn ratively, geochemical techniques can be used to infer catchment erosion rates, as is as techniques do not rely on the amount of material deposited in the basin.

\section{Inorganic geochemical D: Jxies for catchment erosion, weathering, and terrestrial hat: at change}

\subsection{Element geochemistry as a $p \circ x)$ ior erosion and weathering}

The advent of X-ray fluorescer e ( $\mathrm{\Lambda} R \mathrm{~F})$ core scanning techniques over the past decades has made it increasingly fas ${ }^{+}$a. $\backslash$ efficient to obtain continuous, highly-resolved records of elemental intensities $\left(m_{c}\right.$ srured as counts integrated over exposer time of analyses) from sedimentary 'cuscions (e.g. Croudace et al. 2006; Croudace et al. 2019a). Elements associated $v^{r i t}$. minerogenic matter (traditionally $\mathrm{Al}, \mathrm{Si}, \mathrm{K}, \mathrm{Ti}, \mathrm{Fe}, \mathrm{Rb}, \mathrm{Zr}$ ) can be used qualitatively to semi-quantitatively for estimating detrital matter abundances in sedimentary sequences, which is a measure for the amount of detrital material delivered to a sedimentary basin (Davies et al. 2015). The amount of sediment delivered to a lake basin is then often used as qualitative proxy for catchment erosion (e.g. Wennrich et al. 2014; Davies et al. 2015; Francke et al. 2016). Such interpretations can however be biased by mutual dilution with other sedimentary matter deposited at the coring site. Low intensities in siliciclastic-related elements can then for example be controlled by the deposition of more authigenic matter at the coring location, often misleadingly interpreted as less detrital matter supply to the lake and less erosion in the catchment. High-resolution, qualitative to semi-quantitative variability in XRF elemental intensities 
is thus ideally supported by quantitative information about the amount of detrital matter in the sediments, which can be modelled (usually at lower resolution) as outlined in section 2. Where quantitative estimates of detrital sediment deposition at the coring site are not available (for example where chronological data are not robust, cf. section 2 ), the interpretation of elemental intensities as proxy for detrital sediment accumulation is often (qualitatively) evaluated in the light of authigenic matter concentrations and sedimentation rates as inferred from the age-depth model. For example, decreasing $\mathrm{K}$ intensities in the sediments of Lake Ohrid (North Macedonia, Albania) during the Early Holocene, are not indicative of decreasing detrital matter supply and reduced catchment erosion (Fig. 2, Francke et al. ?019). Instead, increasing TOC contents (total organic carbon as proxy for the amount, f organic matter) and low

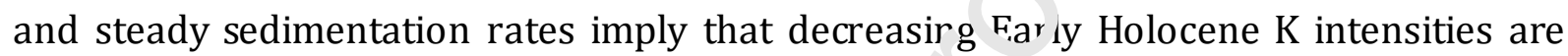
rather driven by mutual dilution. Low $\mathrm{K}$ inter sives during the Mid-Holocene are balanced by moderate TOC and very high TIC (tnta inorganic carbon as proxy for the amount of endogenic calcite), whilst sedimen $\mathrm{a}^{+}, \mathrm{c} n$ rates are similar to those of the Early

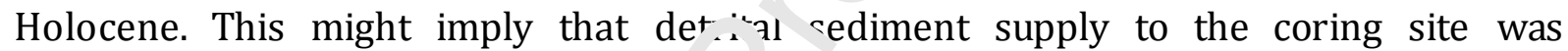

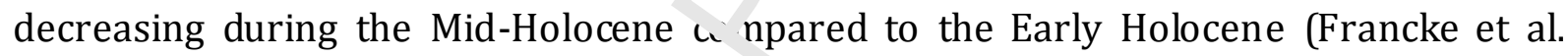
2019).

Fig. 2: Late Glacial to Holocent 'bio-)geochemical proxy data from the sediments of Lake Ohrid (North Macedonia, A'rar:i). Relative variability in TIC (total inorganic carbon as proxy for endogenic calcite, "OC (total organic carbon as proxy for organic matter), $K$ intensities (as proxy, $f_{0,} t^{\prime}$ ie amount of detrital matter) and sedimentation rates (as inferred from an age ${ }^{2}$ pth model based on tephrochronology) can be used to semiquantitatively infer the amount of detrital matter supplied to the lake. Detrital matter supply to a lake can be used as proxy for catchment erosion but is ideally supported by quantitative data, which can be modelled as outlined in section 2. Ti/K and the carbon isotope composition of organic matter ( $\delta^{13} C_{\mathrm{org}}$ ) are used as proxies for soil development in the catchment (section 3.1 and 3.2). Decreasing soil development during the Late Holocene is a result of increasing human land use and soil degradation. All data from Francke et al. (2019). Carbon isotope analyses was previously conducted at lower resolution by Zanchetta et al. (2018), who also provide proxy interpretation. 
Information about the degree of chemical weathering in detrital matter as a measure for soil development in the catchment is usually inferred by normalizing chemically mobile (K, Sr, Ca) to more immobile elements (Ti, Al, Si, Rb, Zr) (Brown 2011; Unkel et al. 2010; Vogel et al. 2015). Ti/K ratios have for example successfully been used as proxy for soil development in the catchment of Lake Ohrid during the Late Glacial to Holocene (Fig. 2, Francke et al. 2019). Decreasing Ti/K ratios in response to Early to Mid-Holocene warming have been interpreted as increasing $\mathrm{K}$ mobilisation by chemical weathering in the catchment. The aqueous $\mathrm{K}$ is then taken up in the interlayer spaces of phyllosilicates, in interstitial sites of calcite, and adsorbs to clay surfaces and organic matter. Other elemental ratios, such as $\mathrm{Rb} / \mathrm{Sr}, \mathrm{Rb} /$ inc (incoherent scatter I, Ir/inc, $\mathrm{Zr} / \mathrm{Fe}, \mathrm{Fe} / \mathrm{Si}, \mathrm{Fe} / \mathrm{Ti}$ have been used as indicators for variations in the particis sice diameter in a sediment core. These variations can provide crucial insights th to erosion, sediment transport energy, and incision rates in rivers and creeks $d r_{\text {air }}{ }^{-1}{ }_{1}$ o into the lake (Van Daele et al. 2014; Marshall et al. 2011). Extensive analysis nt . atchment and surface sediment at Lake Towuti have for example revealed that ' $\mathrm{h}$, s sdiment's $\mathrm{Al} / \mathrm{Mg}$ ratios in the northern part of the basin are closely related $t, t_{t}$ kaolinite-to-serpentine ratio. This ratio is controlled by tectonic activity and mas. wasting, river incision into the un-weathered, kaolinite-poor, ultramafic bedrock, and grain size (Hasberg et al. 2019; Morlock et al. 2018; Vogel et al. 2015). On geol( g ć ny short time scales, $\mathrm{Al} / \mathrm{Mg}$ is then used as proxy for hydrological changes since t responds sensitively to river incision in the catchment and grain size at the drill si: $`$. latter being a measure for shoreline distance and lake level (Morlock et al. 2018. $\vee$ rel et al. 2015).

Information about la. $d_{s}$ e evolution as inferred from elemental intensities and ratios might be biased by a $\mathrm{F}^{\sim} \mathrm{s}$ connectivity of the catchment (connectivity between hillslope, fluvial system and lake basin), sediment redistribution by lake-internal currents, and the additional deposition of aeolian material as discussed previously (section 2). Interpretations from elemental intensities and ratios need to be evaluated additionally in the light of site-specific settings including bedrock geology and grain size, since changes in sediment source and grain size sorting might impact the geochemical composition of detrital sediments (Kylander et al. 2011; Davies et al. 2015). For example, Ti/K ratios have been used as proxy for the intensity of chemical weathering at lakes Ohrid (North Macedonia, Albania, cf. Fig. 2) and Bourget (France) (Francke et al. 2019; Arnaud et al. 2012), but as an indicator for grain size variability at Lake Tana (Marshall et al. 2011). The site-specific characteristics might even vary between cores 
from the same basin if detrital matter is supplied from areas of different bedrock geologies in the same catchment. Interpretations are thus ideally supported by additional proxy analyses and statistical analyses, conducted on a robust set of subsamples from the depositional archive and the source material (weathering horizons and bedrock in the catchment). Additional proxy analyses of depositional archives usually encompass particle size, mineralogical, and/or traditional XRF analyses, whilst catchment samples are analysed for their geochemical and mineralogical properties.

Care has to be taken when interpreting data for elements such as Si, Ca and Sr that occur in both detrital and non-detrital matter. High Si intensities, in particular if normalized to $\mathrm{Ti}$, have been used as indicator for the amount of diaton frustules and/or sponge needles in sediments (Wennrich et al. 2014), whilst other ${ }^{3} \mathrm{u}^{+}$nors used it as a proxy for detrital matter flux or grain size (e.g. Cuven et al. 201 $\iota \cdot$ V', gel et al. 2015). Similarly, Ca and $\mathrm{Sr}$ intensities are frequently used as indicator $\hat{N}$ r he amount of calcium carbonate in the sediments (e.g. Vogel et al. 2010a), since Sr ras a high affinity to replace Ca in crystal lattices (De Choudens-Sanchez and G or Lc lez 2009). At sites with an insufficient supply of dissolved $\mathrm{Ca}^{2+}$ and $\mathrm{HCO}_{3}^{-}$ion , ' ${ }^{2} \mathbf{1}^{-}$ore carbonate bedrock is scarce or absent), authigenic or endogenic calcium carbo . tes can be absent in sediments. In such cases, both $\mathrm{Ca}$ and $\mathrm{Sr}$ may originate fron. Ca-bearing feldspars, and consequently provide insights into the geochemical con.p ss cion of detrital matter (e.g. Wennrich et al. 2014; Vogel et al. 2015).

The occurrence of mm-scal c c trital laminae in the lithological record can be a useful tool to reconstruct past $\mathrm{fl}_{\mathcal{L}}$ events if they are identified as an indicator of greater hydrodynamic ener s.' if streams draining into the lake (Schillereff et al. 2014). Detecting flood laj s in a depositional archive requires highly detailed sedimentological and grain size analyses for differentiation against (tectonic-induced) aerial or subaerial mass wasting and hemi-pelagic background sedimentation (Arnaud et al. 2016). Where flood-related deposition has been confirmed for a specific site, highresolution records of the frequency and intensity of floods can be established by means of $\mu$-XRF scanning. $\mu$-XRF scanning allows identification of flood layers either by highlighting distinct differences in geochemical composition compared to the hemipelagic background sedimentation, or by providing analyses of grain-size-sensitive elemental ratios, since flood layers are usually associated with coarser grain size distributions (Schillereff et al. 2014). The abundance of flood events is then directly related to the frequency of detected flood layers in the record. Flood intensity can be 
inferred either by flood layer thickness or grain size distribution (Arnaud et al. 2016). Determining the particle size (directly or indirectly by $\mu$-XRF scanning) is considered to be the more appropriate approach over measuring the thickness of discrete layers (Lapointe et al. 2012). As for the application of elemental ratios and intensities to hemipelagic sediments, the validity of the palaeoflood record depends strongly on a detailed understanding of lake internal sediment re-distribution processes (Schillereff et al. 2014; Arnaud et al. 2016). For instance, a comparison of two cores from different locations at Lake Allos (Mediterranean French Alps) has shown that hyperpycnaldominated sites have more complex flood sediment redistribution patterns, requiring the investigation of several cores (Wilhelm et al. 2015). Graı size variability has been proposed as the only suitable method for flood reconstr.eti uns at sites dominated by hyperpycnal flows (Wilhelm et al. 2015). Contrastinçly, at the second site at Lake Allos, which is dominated by homopycnal flows, deposi. 'iciness could be used as a palaeoflood indicator, and the analysis of one single core yı ded sufficient results.

$\mu$-XRF scanning on palaeoflood records ca: ' $\lrcorner \in$ applied to wet sediment cores or to resin-impregnated sediment blocks $\mathrm{U}$, in thin section preparation (Cuven et al. 2010). XRF on resin-impregnated sediı. $\lrcorner$ nt blocks facilitate for matrix effects resulting from different water contents in wet inre samples. The preparation of thin sections from sediment blocks sampled from a 10 e includes freeze-drying and resin saturation under low vacuum, and is therefore 1 lativ ely time consuming compared to $\mu$-XRF scanning on fresh, wet sediment core uri?ces. $\mu$-XRF on resin-impregnated sediment blocks is consequently only useful is : can provide a significant improvement in data quality, or where sediments art no ${ }^{-r 1}$. consolidated. Other approaches to overcome the problem of poorly consolidated sc diments being difficult to analyse with a XRF core scanner, mainly in very young, historical sedimentary successions, includes the recently introduced iBox-FC containment vessel for $\mu$-XRF scanning on freeze cores since it prevents thawing by up to two hours (Gregory et al. 2019).

Additional confidence in the interpretation of elemental intensities and ratios can be gained by calibration methods and comparisons of XRF scanning data to conventional XRF analyses at lower resolution. Several calibration methods have been proposed in the literature, for example by accounting for the sediment's water content (Boyle et al. 2015). If a lower sample resolution ( $\mathrm{cm}$ to $\mathrm{dm}$ resolution) has been identified as sufficient for a given sediment core, discrete, powdered samples can be analysed using an XRF core scanner. This minimizes matrix effects (water content, grain size, 
mineralogy) while still making use of a higher cost- and time-efficiency compared to traditional bench top XRF analyses (Profe and Ohlendorf 2019). Univariate and multivariate log-ratio calibration methods have been proposed by Weltje and Tjallingii (2008) and Weltje et al. (2015). Multivariate log-ratio calibrations can provide "absolute" concentrations at a precision similar to those of traditional XRF analyses, but require the analyses of a robust calibration dataset by means of conventional XRF (Weltje et al. 2015). Absolute element concentrations as obtained from XRF scanning can be used for flux or mass-balance calculations at high resolution over time, which is of particular interest for comparisons between several sites (Weltje et al. 2015). The determination of absolute concentrations could even allow th: calculation of traditional chemical alteration indices, such as the Chemical Ind v ef Weathering (CIW), the Weathering Index (WI), the Weathering Potential Inde- (V PI), or the Chemical Index of Alteration (CIA, Price and Velbel 2003; Harns is 1;88). These indices essentially measure the degree of depletion between mobile $a_{1} . \tau$ immobile elements derived from molar mass concentrations of aluminium oxi ff $\left(\mathrm{Al}_{2} \mathrm{O}_{3}\right)$, calcium oxide in silicates (CaO), sodium oxide $\left(\mathrm{Na}_{2} \mathrm{O}\right)$, and potassium $\mathrm{o}^{\mathrm{T}} \mathrm{e}\left(\mathrm{K}_{2} \mathrm{O}\right)$. The CIA, for example, is modelled as follows (Nesbitt and Young 1982).

$$
\mathrm{CIA}=\left[\mathrm{Al}_{2} \mathrm{O}_{3} /\left(\mathrm{Al}_{2} \mathrm{O}_{3}+\mathrm{CaO}+\mathrm{Na}_{2} \mathrm{O}+\mathrm{K}_{2}\right)_{-}\right]_{1} \times 100
$$

Complications arise from titi-ulties in accounting for the contributions of detrital,

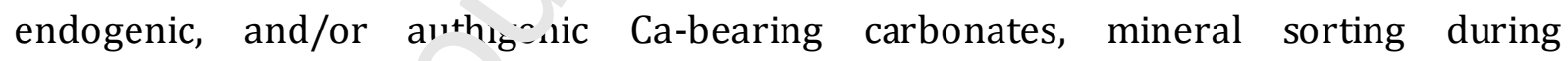
transportation, and r $^{2}$, $d$ positional addition of $\mathrm{K}$ due to processes such as illitisation (Goldberg and Humay $\cdots, 2010$ ). If analyse by core scanning technologies, the application of such indices is still limited since current XRF scanner are not able to detect Na. Elemental ratios are thus still the preferred approach for inferring the degree of chemical alteration in sediments (Arnaud et al. 2016).

\subsection{Bulk inorganic carbon isotopes for rock, soil and vegetation interactions}

During precipitation of (endogenic) inorganic materials, such as carbonates (e.g. calcite, aragonite) in epilimnetic waters or speleothem, the newly formed mineral captures the relative proportion of ${ }^{12} \mathrm{C}$ and ${ }^{13} \mathrm{C}$ isotopes present in the dissolved inorganic carbon pool $\left(\delta^{13} C_{\text {DIC }}\right)$. This makes endogenic inorganic materials a useful tracer for landscape evolution and an archive of terrestrial environmental change. 
For most hard water lakes in limestone catchments, $\delta^{13} \mathrm{C}_{\mathrm{DIC}} \mathrm{can}$ be approximated to the $\delta^{13} \mathrm{C}$ of bicarbonate $\left(\mathrm{HCO}_{3}^{-}\right)$, which is the main carbon species present at neutralalkaline $\mathrm{pH}$. As there is only a minor change in $\delta^{13} \mathrm{C}$ during the precipitation of carbonate from lake water (Romanek et al. 1992), the $C$ isotope composition of the mineral phase $\left(\delta^{13} \mathrm{C}_{\text {carb }}\right)$ can provide information of past variations in $\delta^{13} \mathrm{C}_{\mathrm{DIC}}$ (Leng and Marshall 2004). The isotope signal of epilimnetic waters is ideally retrieved from inorganicallyprecipitated formed carbonates, since biological carbonates (e.g. shell fragments) can be affected by different isotope fractionation processes (vital effects), temperature differences between surface (where endogenic carbonate formation takes place) and bottom waters, the timing of carbonate precipitation, ant productivity-controlled stratification of the DIC pool (Leng and Marshall 2004; L.ce y et al. 2018). Vital effects might have only limited impact on recorded $\delta^{13} C$ in biogenic carbonates, whilst temperature, timing, and stratification might pla a n.ore dominate role (Lacey et al. 2018).

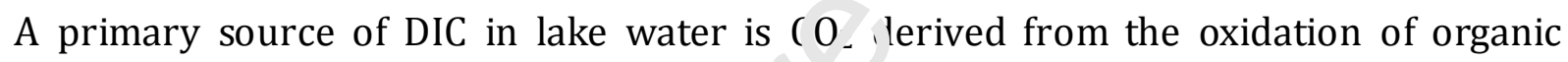

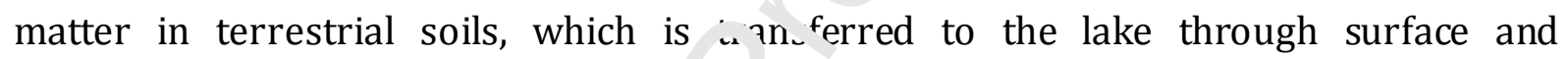
groundwater inflows. The $\delta^{13} \mathrm{C}$ of DIC s oplied to the lake is dependent on the type of photosynthetic metabolism used by we source vegetation ( $\mathrm{C}_{3}$ vs. $\mathrm{C}_{4}$; see section 4.1$)$. As organic matter accumulates in sois ar u degrades, $\mathrm{CO}_{2}$ is produced with a negligible $\delta^{13} \mathrm{C}$ offset (Sharp 2007). Following dissulution in superficial waters, the soil-derived $\mathrm{CO}_{2}$ is hydrated to produce carbo ric acid that dissociates, depending on $\mathrm{pH}$, to $\mathrm{HCO}_{3}$ - with a consistent $\delta^{13} \mathrm{C}$ offset from L $_{\text {- }}$ parent $\mathrm{CO}_{2}$ (Mook et al. 1974). Therefore, the extent and type of vegetation c 've: ir. a catchment, rate of soil development, and amount of $\mathrm{CO}_{2}$ leaching are primary $\sim n$ trols on the availability and $\delta^{13} \mathrm{C}$ of soil-derived $\mathrm{CO}_{2}$. In turn, these variables are driven by palaeoenvironmental and hydroclimate changes, which is a function of oscillations between contrasting glacial and interglacial climates on orbital timescales (Zanchetta et al. 2018). Soil-derived $\mathrm{CO}_{2}$ may be considered a source of low $\delta^{13} \mathrm{C}$ to lake DIC, even when taking into account differences between $\mathrm{C}_{3}$ - and $\mathrm{C}_{4}$ dominated catchments, in comparison to geological sources of carbon. Supply of soilderived $\mathrm{CO}_{2}$ with low $\delta^{13} \mathrm{C}$ can also be recorded in the carbon isotope composition of the organic matter pool ( $\delta^{13} \mathrm{C}_{\mathrm{org}}$ ), if organic material preserved in the sediments is mainly of aquatic origin (Zanchetta et al. 2018). In such a scenario, decreasing $\delta^{13} \mathrm{C}$ can be used as an indicator for soil development in the catchment. This has for example been shown for the Late Glacial to Holocene sediments of Lake Ohrid, where the interpretation of $\delta^{13} C_{\text {org }}$ 
is further supported by elemental ratios as inferred by XRF core scanning (cf. section 3.1 and Fig 2, Francke et al., 2019).

Weathering and dissolution of catchment carbonate rocks, typically of a marine affinity, produces significantly higher $\delta^{13} \mathrm{C}$ compared to respired soil organic matter (Diefendorf et al. 2008). However, an increased rate of soil respiration lowers the $\mathrm{pH}$ of surficial waters and soil-derived $\mathrm{CO}_{2}$ may be consumed by carbonate dissolution (Jin et al. 2009), thereby buffering any decrease in $\delta^{13} \mathrm{C}_{\mathrm{DIC}}$ of lake water. Dissolution processes can also impart a threshold behavior for carbonate precipitation in lakes. Catchment soil development, decay, and subsequent $\mathrm{CO}_{2}$ liberation may be catalysts for the enhanced dissolution of geological carbonates, increasing the supplv $\mathrm{O}_{1}^{-} \mathrm{Ca}^{2+}$ and $\mathrm{HCO}_{3}^{-}$ions to a lake and supporting epilimnetic carbonate precipitation ( $\mathrm{L}\urcorner \mathrm{ce}$ y et al. 2016).

Whilst the presence of forested catchments, and the as oc ated availability and transfer of soil-derived $\mathrm{CO}_{2}$ and dissolved geological carb $\sim_{11}, \eta_{1}$ a often driven by regional-scale hydroclimate evolution, changes in vegetation cores also affect evapotranspiration. This applies to natural, climate-driven shifts in landscape development and also anthropogenic catchment deforestatior. W W indward et al. 2014). A decrease in forest cover and lower evapotranspiration ra $\lrcorner$ s may facilitate enhanced water yield from a catchment area and increase the cintribution from geological carbon sources with higher $\delta^{13} \mathrm{C}$ to lake DIC. In catchne at, with a constant vegetation assemblage or when considering multi-millennial ti.. 'escales, as well as in recent sediments, variations in the concentration and $\delta^{13} \mathrm{C}$ of a ${ }^{2} m u$-pheric $\mathrm{CO}_{2}\left(\delta^{13} \mathrm{C}_{\mathrm{CO}}\right)$ ultimately influences $\delta^{13} \mathrm{C}_{\text {DIC }}$ via the soil $\mathrm{CO}_{2}$ leaching- $\mathrm{HCO}_{3}{ }^{-} \mathrm{na}_{2}{ }^{\text {hv }}$ vay or by direct exchange with lake water. For extended records that cover a $r$ glacial-interglacial cycles, a traceable change in $\delta^{13} \mathrm{C}$ of vegetation and subsec $_{1}$. nt soil-derived $\mathrm{CO}_{2}$ may be the product of variations in ${ }^{13} \mathrm{C}_{\mathrm{CO}}$ assimilated during photosynthesis (Hare et al. 2018). Similar changes have been brought about in recent decades due to the anthropogenic burning of fossil fuels resulting in lower $\delta^{13} \mathrm{C}_{\mathrm{CO} 2}$, which will be reflected in the $\delta^{13} \mathrm{C}$ of terrestrial biomass and can be taken into account when interpreting isotope records (Keeling 1979).

Following the transfer and incorporation of soil-derived $\mathrm{CO}_{2}$ or geological sources of carbon to lake DIC, internal lake processes can act to modify $\delta^{13} \mathrm{C}_{\mathrm{DIC}}$. Whilst alteration of $\delta^{13} \mathrm{C}_{\mathrm{DIC}}$ can be the result of natural factors, such as enhanced primary productivity (higher $\delta^{13} \mathrm{C}$ ) or greater recycling of organic matter (lower $\delta^{13} \mathrm{C}$ ), human impact on catchment areas may also drive and exacerbate in-lake modification of $\delta^{13} \mathrm{C}_{\text {DIC. }}$. Agricultural intensification over the $20^{\text {th }}$ century and increased external nutrient loading 
on lakes can lead to eutrophication and excess carbon sequestration (Anderson et al. 2014), driving higher $\delta^{13} \mathrm{C}_{\mathrm{DIC}}$ given the preferential use of ${ }^{12} \mathrm{C}$ by aquatic primary producers. Although the influence of human impact on $\delta^{13} \mathrm{C}_{\mathrm{DIC}}$ may overprint variations imparted by environmental change, $\delta^{13} \mathrm{C}_{\mathrm{DIC}}$ may still ultimately be a product of landscape change during anthropogenic modification of catchments. In lakes that are dominated by autochthonous organic matter production, the dependence of $\delta^{13} \mathrm{C}_{\mathrm{DIC}}$ on catchment-derived soil $\mathrm{CO}_{2}$ can mean that the presence of terrestrial organic matter components is not necessarily a prerequisite for understanding past landscape change. Past variations in $\delta^{13} \mathrm{C}_{\text {carb }}$ and $\delta^{13} \mathrm{C}_{\text {org }}$ in such systems, albeit with a $\delta^{13} \mathrm{C}$ offset imparted during photosynthesis, may be positively correlated as $\mathrm{bu}^{\text {th }}$ are driven by $\delta^{13} \mathrm{C}_{\mathrm{DIC}}$ (Zanchetta et al., 2018).

The carbon isotope signal recorded in speleothem a ch ves preserves the same soil development and/or vegetation dependent $\delta^{13} \mathrm{C}$ vi. in hity as discussed for lake records. The interpretation of speleothem-derived $\delta^{13} \mathrm{C} \mathrm{r}_{t}$ ords are frequently simplified in comparison to lacustrine archives since previs sis discussed lake-internal modifications of the desired catchment signal do not r ${ }_{r}$ ly. Speleothem records furthermore benefit in particular from a high-precision, inde ${ }_{r}$-ndent chronology, as derived from uraniumthorium dating. Most non-metal isou ne studies applied to speleothem records focus in particular on the recorded hydro c'in idtic history mainly inferred from oxygen isotope $\left(\delta^{18} 0\right)$ compositions of carboi, te ininerals (e.g. Bar-Matthews and Ayalon 2004), and carbon isotopes are traditic rai, an essential part of such studies. The potential of stable carbon isotope composition. of speleothem records as key data for soil stability and pedogenesis has recu $n t_{1}$, $h$ sen highlighted by Regattieri et al. (2019). The authors report a complex interplay $b+$ ween climate, vegetation development, human land use, and soil erosion in the European Alps during the last 10,000 years, as inferred from $\delta^{13} \mathrm{C}, \delta^{18} \mathrm{O}$, and magnetic susceptibility.

\subsection{Metal stable and radiogenic isotopes for erosion and weathering}

\subsubsection{Uranium isotope activity ratios as indicator for catchment erosion}

The activity ratio of uranium isotopes $\left({ }^{234} \mathrm{U}\right.$ and $\left.{ }^{238} \mathrm{U}\right)$ in fine-grained detrital matter can provide quantitative estimates of catchment-wide erosion processes (e.g. DePaolo et al. 2006; DePaolo et al. 2012; Dosseto and Schaller 2016; Lee et al. 2010b; Francke et al. 2019; Rothacker et al. 2018; Martin et al. 2019). Mineral grains undergo on-going depletion of ${ }^{234} \mathrm{U}$, which is measurable in the $<63 \mu \mathrm{m}$ size fraction characterised by a 
high surface-to-volume ratio. This depletion occurs by a) direct recoil of ${ }^{234} \mathrm{Th}$, an intermediate product between ${ }^{238} \mathrm{U}$ and ${ }^{234} \mathrm{U}$, (b) preferential leaching of ${ }^{234} \mathrm{U}$ embedded in the recoil tracks, and (c) preferential oxidation of ${ }^{234} \mathrm{U}$ compared to ${ }^{238} \mathrm{U}$ (Dosseto et al. 2008; Suresh et al. 2014b, 2013; Ma et al. 2010; Gontier et al. 2015, cf. Fig. 3). Recoil describes the physical displacement of the daughter nuclide (herein: ${ }^{234} \mathrm{Th}$ ) during radioactive $\alpha$-decay (herein of ${ }^{238} \mathrm{U}$ ) and can result in the ejection of the daughter nuclide into the surrounding pore space in an open system (Fig. 3). Whilst the decay to ${ }^{234} \mathrm{Th}$ is responsible for the physical displacement, ${ }^{234} \mathrm{U}$ is targeted during isotope analyses for this method since ${ }^{234} \mathrm{Th}$ and ${ }^{234} \mathrm{~Pa}$ rapidly decays into ${ }^{234} \mathrm{U}$ (Fig. 3).

Fig. 3: Uranium isotopes $\left({ }^{234} U\right.$ and $\left.{ }^{238} U\right)$ in fine-grained st tir ent. Half-lives of ${ }^{238} U,{ }^{234} U$ and intermediate nuclides ${ }^{234} \mathrm{Th}$ and ${ }^{234} \mathrm{~Pa}$ are also sho ${ }^{\prime \prime n}$ Recoil during the $\alpha$-decay of ${ }^{238} \mathrm{U}$ to ${ }^{234} \mathrm{Th}$ results in a physical displacement of $\mathrm{t}^{\mathrm{l}}{ }_{\mathrm{c}}$. ${ }^{\mathrm{J}} \mathrm{an}$ ghter nuclide by $\sim 30 \mathrm{~nm}$ (in most silicates). Half-live for ${ }^{234}$ Th and ${ }^{234} \mathrm{~Pa}$ (hours to dcys, are not relevant on geological time scales. Loss of ${ }^{234} U$ occurs mainly in the outer ri $n$ of fine-grained $(<63 \mu \mathrm{m})$ detrital grains by recoil of ${ }^{234}$ Th (and subsequent dec'.y to ${ }^{234} U$ ) or preferential leaching of ${ }^{234} U$. Nondetrital matter (organic matter, authigt. 'c and endogenic minerals) are usually enriched in ${ }^{234} U$ and have to be removed carefu.". from the bulk sediment prior to analysis. Modified from Martin et al. (2015).

The $\left({ }^{234} \mathrm{U} /{ }^{238} \mathrm{U}\right)$ activity rat: $\iota^{f}$ fine-grained sediments ( $\left.\mathrm{A}_{\text {meas }}\right)$ decreases on geological time scales mainly in resno. $\sim$ a to recoil (process (a)) and is thus a measure of the time elapsed since comı $\eta_{\omega^{+}}{ }^{\text {ir }} \mathrm{n}$ of the bedrock or coarse $(>63 \mu \mathrm{m})$ regolith (both not showing depletion of ${ }^{22}+\mathrm{U}$ ) into fine-grained detrital matter, termed comminution age (DePaolo et al. 2006; Lee et al. 2010b; Dosseto and Schaller 2016). For a sedimentary deposit, the sediment residence time of detrital matter in the catchment ( $t_{r e s}$, in yr) is the difference between the comminution age and the deposition age, and can be calculated as follows (Francke et al. 2019, Fig. 4):

$$
t_{\text {res }}=-\frac{1}{\lambda_{234}} \ln \left[\frac{\left[A_{\text {meas }}-\left(1-f_{\text {post }}\right)\right] e^{-\lambda_{234} t_{\text {dep }}+\left(1-f_{\text {post }}\right)-\left(1-f_{\text {pre }}\right)}}{A_{0}-\left(1-f_{\text {pre }}\right)}\right]
$$

with $\lambda_{234}$ as the ${ }^{234} U$ decay constant (in $\left.y^{-1}\right)$, Ameas and $A_{0}$ as the measured $\left({ }^{234} U /{ }^{238} U\right.$ ) activity ratios (unitless) and at time zero (i.e. onset of comminution), and $f_{\text {pre }}$ and $f_{\text {post }}$ are 
the recoil loss factors prior and after to deposition (unitless). The recoil loss factor is the fraction of ${ }^{234} \mathrm{U}$ that is recoiled out of mineral grains. It is calculated as follows (Maher et al. 2006; Kigoshi 1971):

$f=\frac{1}{4} L S \rho$

where L is the recoil length of ${ }^{234} \mathrm{Th}$ (30 $\mathrm{nm}$ on average in common silicate minerals; Dosseto and Schaller, 2016), $\rho$ the density of the sediment (usually $2.6 \mathrm{~g} / \mathrm{cm}^{3}$ ), and $\mathrm{S}$ the surface area of the sediment $\left(\mathrm{m}^{2} / \mathrm{g}\right)$ as measured by ga ; sorption analysis. Thus, in depositional archives where the deposition age is knowr., it is possible to reconstruct past variations in sediment residence time.

Fig. 4: Conceptual model of detrital matter transit an a ${ }^{234} U$ depletion from source to sink Depletion of ${ }^{234} U$ starts in fine-grained detrital mc cter that is produced as the weathering front on the hillslopes migrates downward cv tine. Further lowering of the $\left({ }^{234} \mathrm{U} /{ }^{238} \mathrm{U}\right)$ activity ratio occurs in any process relr cen to :illslope and fluvial storage and transport, and during final deposition in a sedimen . ry basin. The $\left({ }^{234} U / 238 U\right)$ activity ratio can be used to estimate the palaeo-sediment, s sidence times if the time since final deposition is excluded. Modified after Dosseto $n$ nd s, haller (2016).

The application of U-isotop's as a proxy for catchment erosion requires several considerations (e.g. Do st $)$ and Schaller 2016; DePaolo et al. 2012). Firstly, authigenic and organic phases $n \curvearrowright a$ to be eliminated during pre-treatment without altering the outer rim of detrital grains such that the $U$ isotope composition of detrital grains is measured only. Several sequential extraction protocols have been proposed (Suresh et al. 2014a; Martin et al. 2015; DePaolo et al. 2006; Maher et al. 2004; Lee et al. 2010a; Menozzi et al. 2016; Francke et al. 2018). Recently, Francke et al. (2018) have introduced a pre-treatment protocol that allows for the fast processing of large sample sets while meeting the requirements for detrital grain isolation.

The second consideration addresses the initial $\left({ }^{234} \mathrm{U} /{ }^{238} \mathrm{U}\right)$ activity ratios, which is often assumed to be 1, representing secular equilibrium in an un-weathered bedrock. Secular equilibrium is achieved within a time equivalent five times the daughter's half-life. This restricts the application of $U$ isotopes to comminution ages of sediments younger than 1 
Ma. Moreover, bedrock often shows ${ }^{238} \mathrm{U}-234 \mathrm{U}$ disequilibrium even in bedrock older than $1 \mathrm{Ma}$ as a result of deep weathering and fracturing (Handley et al. 2013b; Dosseto and Schaller 2016; Martin et al. 2019). Three potential scenarios have been proposed to address ${ }^{238} \mathrm{U}-234 \mathrm{U}$ disequilibrium in bedrock material: Firstly, Dosseto and Schaller (2016) argued that the depletion of ${ }^{234} \mathrm{U}$ in source rocks is irrelevant since the isotope ratio is "reset" during comminution as illustrated by glacial outwash measured close to secular equilibrium (DePaolo et al. 2012). This implies that an initial activity ratio $A_{0}$ of 1 can be used for equation (2). Secondly, Martin et al. (2019) propose that $A_{0}$ used in equation (2) can be calculated for a given catchment by accounting for the relative spatial contribution of each rock type and their $\left({ }^{234} \mathrm{U} /{ }^{238} \mathrm{U}\right)$ activity ratios. This requires an a priori knowledge of $\left({ }^{234} \mathrm{U} /{ }^{238} \mathrm{U}\right)$ activity ratios in t ${ }^{3} \mathrm{cr}$ rock type, which can be measured for any given catchment on a statistically $\mathrm{r}$ br'st set of bedrock samples or inferred from the literature. Finally, the assumptic $\Lambda^{+}{ }^{\dagger}$ an initial activity ratio A0 of 1 can be relaxed if $A_{0}$ is randomly chosen by Monte-Carlo s mulations between set values, with the set values being inferred from literature ( $a$ 'a or direct measurements (Francke et al. 2019).

A third consideration addresses the impact of preferential leaching of ${ }^{234} \mathrm{U}$ on $\left({ }^{234} \mathrm{U} /{ }^{238} \mathrm{U}\right)$ activity ratios of fine-graı ed detrital matter after comminution. Martin et al. (2019) calculated comminution ag's ior fluvial sediments in northern Australia based on an formulation introduced $L_{2}$ r Dosseto and Schaller (2016). This formulation accounts for preferential leaching, the : elaxing the assumption that loss of ${ }^{234} \mathrm{U}$ in fine-grained detrital matter is contrnllt d by recoil only. Sensitivity tests revealed that estimated comminution ages $u_{1}, \mathrm{nt}_{\mathrm{C}} \mathrm{d}$ in particular on the chosen ${ }^{238} \mathrm{U}$ leaching rate (Martin et al. 2019). Using the form.' 'ation to account for preferential leaching, however, resulted in poor correlations between sediment residence times, vegetation cover, and annual rainfall, which were otherwise evident if not accounting for preferential leaching (loss of ${ }^{234} \mathrm{U}$ by recoil only). This can probably be attributed to a complete dissolution of the weathering-active surface on geologically short time scales (Li et al. 2018). This implies that measured $\left({ }^{234} \mathrm{U} /{ }^{238} \mathrm{U}\right)$ activity ratios of fine-grained detrital matter reflect the recoil-induced loss of ${ }^{234} \mathrm{U}$ from the weathering-inactive mineral surface only, and that preferential leaching is insignificant for the comminution dating approach (Li et al. 2018).

The fourth consideration addresses the requirement of accurate determination of the recoil loss fraction $f$ (equation 3). Because there is a two-order magnitude difference 
between the length scale of ${ }^{234} \mathrm{Th}$ recoil and the length of the molecule $\mathrm{N}_{2}(0.354 \mathrm{~nm})$ used for surface area quantification, the estimated the recoil loss fraction using gas sorption analysis can result in an overestimation of the surface area relevant to ${ }^{234} \mathrm{Th}$ recoil. To address this difference, a fractal correction has been proposed (Bourdon et al., 2019). Francke et al. (2018) have shown, however, that the fractal correction should only be applied if micro- $(<2 \mathrm{~nm})$ or/and meso-pores $(2-50 \mathrm{~nm})$ are present in the sediments, which can be assessed during gas sorption analysis. Gas sorption analysis of selected fluvial sediments from northern Australia (Martin et al. 2019) and lacustrine sediments from Lake Ohrid in the Mediterranean (Francke et al. 2019) has shown that both scenarios (i.e. presence or absence of micro - and meso-p - res) are possible, and the assessment of whether a fractal correction is necessary $h_{1} \cdot{ }^{+} \mathrm{J}$ be undertaken for each study.

The comminution dating approach assumes a uniant recoil loss fraction since comminution, i.e. before and after final deposition. I 'rther considerations have recently been made to address the possibility that the $\epsilon$ zoil loss fraction after final deposition may be different than that during sedir... $t$ ¿ ansport throughout the catchment. Loss of ${ }^{234} \mathrm{U}$ could be significantly inhibited in ensely compacted sediments with small pore space, where ${ }^{234}$ Th could be recoilec' from one grain into another and is thus not lost from sediments (Francke et al. 2r 1', ). Whilst such considerations are probably not significant for relatively uncou oliadted modern stream samples and for Late Glacial to Holocene deposits (Francke et ¿l. 2019), a reduced loss of recoiled ${ }^{234}$ Th after deposition in marine or lacustrine secir.ent cores at greater depths could result in a significant underestimation of $\sim^{-1} c^{\text {ln }}$ ed catchment sediment residence times. Equation (2) allows accounting for differe ${ }^{\mathrm{t}}$ recoil loss fractions before and after final deposition enabling the assessment of loss in ${ }^{234} \mathrm{Th}$ after final deposition in future studies focusing on older time intervals.

The use of $U$ isotopes to infer sediment residence times, sometimes referred as comminution dating was first applied to a marine sediment core and revealed that the provenance of the clastic matter deposited in the North Atlantic might have changed dramatically on glacial-interglacial time scales between Iceland and northern Europe (DePaolo et al., 2006). The inferred variability in comminution ages was thereby attributed to changing sediment sources. During glacial periods, the sediments were dominated by material being previously stored in soils, continental shelves, or elsewhere on the seafloor. Supply of young sediment sourcing from Iceland during 
interglacial periods results in lower comminution ages, i.e. shorter sediment residence times. Since then, comminution dating has mainly been applied to fluvial environments in Australia, China and California (Dosseto et al. 2010; Handley et al. 2013a; Lee et al. 2010b; Martin et al. 2019; Li et al. 2017). This has provided insights about catchmentwide erosion processes in response to vegetation cover and climate parameters on modern to geological time scales.

Martin et al. (2019) reported moderate to strong correlations of $\left({ }^{234} \mathrm{U} /{ }^{238} \mathrm{U}\right)$ activity ratios in modern stream samples from the Gulf of Carpentaria (northern Australia) to annual and seasonal distribution of rainfall, and to vegetation cover in the catchment. $\left({ }^{234} \mathrm{U} /{ }^{238} \mathrm{U}\right)$ activity ratios of modern stream samples from $\mathrm{Cn}_{1}$ 'na have been reported to show an excellent agreement to previously published e.ns'sn rates as inferred from cosmogenic nuclides (Li et al. 2017). Palaeo-channel s dir ients samples in SE Australia show a strong correspondence to glacial-interglac:ai $\mu_{1}$ nate variability, which has been attributed to erosion of young upland soils durins, y 7 cial periods and re-working of old fluvial sediments during interglacials (Dosse o ei al. 2010). Comprehensive multi-proxy studies using the $\left({ }^{234} \mathrm{U} /{ }^{238} \mathrm{U}\right)$ activity, 7 tı alongside traditional palaeoclimate and palynological proxy data have been onducted on two Late Glacial to Holocene lacustrine sediment sequences fron the Balkan Peninsula (Francke et al. 2019; Rothacker et al. 2018, lakes Ohrid and Dojran). These lakes drain small catchments (1002 $\mathrm{km}^{2}$ for Lake Ohrid an $\mathrm{L}^{27 \mathrm{~b}} \mathrm{~km}^{2}$ for Lake Dojran). Whilst in large catchments $\left(\sim>1 \times 10^{6} \mathrm{~km}^{2}\right)$, the $\left({ }^{234} \mathrm{U}^{\prime}{ }^{230}{ }^{-1}\right)$ activity ratio can be modified during fluvial transport and storage (Dosseto et al. $2^{n} 10$; Martin et al. 2019), the sediment residence time in the small catchments tha $a^{2} l_{a}-\mathbf{r}$ significant lateral channel migration mainly reflects hillslope storage. Since the we $\epsilon^{n}$ lering front moves downwards over time, the residence time should decreases with increasing depth in weathering profiles (e.g. Suresh et al. 2013). Consequently in small catchments where fluvial storage is negligible, variations in sediment residence time in depositional archives can reflect changes in hillslope erosion depth over time (Rothacker et al. 2018; Francke et al. 2019). It is thus possible to assess changes in the type of erosion processes, such as deep gullying or mass wasting versus shallow sheet wash, and how these variations relate to changes in vegetation cover and climatic conditions. At Lake Ohrid in North Macedonia and Albania, Late Glacial to Holocene palaeo-sediment residence times and catchment erosion is strongly controlled by climate conditions during the Late Glacial and Early Holocene (Francke et al. 2019, Fig. 5). Shallow erosion of thick soils (long palaeo-sediment residence time) prevails 
during cold and dry climates (Late Glacial, Younger Dryas), and deep erosion of thin soils (short palaeo-sediment residence time) persists during wet and warm intervals (Bølling/Allerød, Early Holocene). The expansion of a dense vegetation cover, as indicated by tree-versus-herb pollen percentages $>90 \%$ (Fig. $5 \mathrm{~B}, \mathrm{C}$ ), suggests that a threshold is crossed in catchment erosion processes during the Early to Mid-Holocene transition. Dense woodland vegetation expanding to high elevations prevents the erosion of thin soils by deep erosion in response to climate forcing. These outcomes display in particular how changes in vegetation cover can impart a threshold-like response in catchment erosion to climate variablity, information that is crucial in the light of increasing anthropogenic deforestation and climate wa"ming.

Fig. 5: A: Late Glacial to Holocene palaeo-sediment $r$ s. der ce times and tree versus herb pollen percentages from Lake Ohrid (Francke et ui. ¿019). YD: Younger Dryas, B/A = Bølling/Allerød. Cold and dry intervals highlighted in nlue are derived from Francke et al. (2019). Grey bar indicates tree-versus-herb roi'en percentages $>90 \%$ indicating the expansion of dense woodland vegetatir.. a all elevations in the catchment. B: Profile across the catchment of Lake Ohrid ar conceptual model of Late Glacial to Holocene catchment erosion showcasing how tir expansion of dense woodland vegetation restricts deep erosion of thin soils at high elev iti un since the Early to Mid-Holocene transition. Thus, as the vegetation cover becom $\epsilon_{\mathbf{2}}$ dominated by trees, climate variability has a more muted role on catchment erosion (cimpared to the Late Pleistocene and Early Holocene). Modified from Francke et nI. ? J19).

\subsubsection{Hafnium ( $\mathrm{Hf})$, nec tymium $(\mathrm{Nd})$ and lead $(\mathrm{Pb})$ isotopes as indicators for sediment source and weathering}

The application of radiogenic isotopes to sedimentary records can provide information on both sediment provenance and the degree of silicate weathering in corresponding soils, which, taken together, can be used to disentangle the impact of climate change and human activities on landscapes. To a first approximation, radiogenic isotope compositions of detrital sediments are mainly set by the parent-daughter ratios and the mean age of the source rocks (e.g. Banner 2004). Compared to other geochemical tracers, neodymium $(\mathrm{Nd})$ isotopes are unique in the sense that their isotopic composition remains mostly unchanged during continental weathering and sediment transport (e.g. Goldstein and Jacobsen 1988). This particularity can be used to 
fingerprint sediment sources and quantify terrigenous fluxes, which help identifying recent periods of enhanced erosion related to land use (e.g. Wan et al. 2015; Giosan et al. 2017; Chatterjee and Ray 2017; Bayon et al. 2019). In contrast to Nd, the distribution of $\mathrm{Hf}$ and $\mathrm{Pb}$ isotopes in detrital sediments is also controlled by weathering and mineral sorting effects. The grain-size and weathering dependence of $\mathrm{Hf}$ and $\mathrm{Pb}$ isotopic ratios in sediments reflects the strong decoupling of corresponding parent-daughter elements (i.e. Lu-Hf and U-Th-Pb) during magmatic processes. The relatively large degree of fractionation between $\mathrm{Lu}$ and $\mathrm{Hf}$ and $\mathrm{U}-\mathrm{Th}$ and $\mathrm{Pb}$ during magmatic crystallization results, with time and radioactive decay of ${ }^{176} \mathrm{Lu}$ to ${ }^{176} \mathrm{Hf}$ and $\mathrm{U}$-series, to markedly different radiogenic isotope compositions in minerals (Ban.er 2004; Blum and Erel 2003). Because weathering does not affect rocks un. ${ }^{c}$ rr nly, these characteristics provide a mean for investigating silicate weatherirg or scesses in soils and detrital sediments (Blum and Erel 1995; Aubert et al. 20/, bayon et al. 2016; Harlavan et al. 1998). Over recent years, this principle was $\mathrm{p}_{\mathrm{r}}$ ied to marine sediment records recovered off the Congo River, in which a par tir u ar sediment horizon is associated with the export of clays with distinctivelv 'ig: $\mathrm{Al} / \mathrm{K}$ ratios and radiogenic $\mathrm{Hf}$ isotopic signatures, indicative of more intense $w$. athering conditions in the watershed (Bayon et al. 2019; Bayon et al. 2012). Becaus - the timing of sediment deposition, around 2500 years ago, coincided with the wice sp ead migration of Bantu-speaking peoples across Central Africa, these particu' $r$ geochemical signatures were partly linked to the intensification of human activi ies and enhanced soil erosion in the rainforest at that time. Similarly, Fontanier $e_{\iota}{ }^{\prime}$. . (2018) also documented a sudden increase in radiogenic Hf signatures in the $\cdot \eta^{n}{ }^{\wedge}$ part of a sediment core offshore north-western Madagascar, interpreted as the rc-ilt of intensifying weathering due to enhanced land use and deforestation over the last 60 years. As emphasized by these examples, silicate weathering can respond rapidly, within a few decades only, to major climatic and/or anthropogenic disturbances on continents.

In addition to detrital sediments, authigenic mineral phases such as iron (Fe) oxides can be also used in sediment records as archives of past weathering and/or anthropogenic activities. Iron oxides form directly in soils upon chemical weathering, being subsequently transported as suspended particulates in rivers prior to deposition as sediments (Bayon et al. 2009). Authigenic Fe oxide phases also commonly precipitate from water in the ocean, rivers and lakes, concentrating substantial amounts of dissolved trace elements such as $\mathrm{Nd}, \mathrm{Hf}$ and $\mathrm{Pb}$, initially released during weathering 
processes or from anthropogenic pollution sources (Boyle et al. 1977; Süfke et al. 2019). A recent investigation of Fe-oxides extracted from sediments deposited in a lake in Switzerland reported a trend towards suddenly increasing radiogenic $\mathrm{Pb}$ signatures from 2200 cal. years B.P., departing from the natural weathering signal of the earlier Holocene period (Süfke et al. 2019). This abrupt change of the $\mathrm{Pb}$ isotopic composition of Fe-oxides coincided exactly with the rise of the Roman Empire and intensification s of mining activity all over Europe, hence suggesting that it corresponded to an atmospheric $\mathrm{Pb}$ pollution signature, in agreement with earlier studies (Renberg et al. 2002). All the examples listed above clearly show the utility of radiogenic isotopes and other weathering proxies in studies aiming to investigate the in nact of humans on the environment.

\subsection{In-situ cosmogenic nuclide analysis for cai hment erosion}

Several of the in situ cosmogenic nuclides, inclucing the stable ${ }^{3} \mathrm{He}$ and ${ }^{21} \mathrm{Ne}$, and the radioactive ${ }^{10} \mathrm{Be},{ }^{14} \mathrm{C},{ }^{26} \mathrm{Al}$, and ${ }^{36} \mathrm{Cl}$, are now $r_{-}$. tinely measured and have been used in geomorphological studies for the last thre de des (Dunai 2010; Granger and Schaller 2014; Bierman 2004). Of these nuclid s, r. owever, ${ }^{10} \mathrm{Be}(\mathrm{T} 1 / 2=1.387 \mathrm{Myr}$, Chmeleff et al. 2010; Korschinek et al. 2010) froduced in quartz is the 'workhorse' for in situ applications, and the majority of 1 . sicu cosmogenic nuclide studies have used ${ }^{10} \mathrm{Be}$, either alone or in conjunction $v \mathrm{it}_{\text {. }}$ o เner cosmogenic nuclides such as ${ }^{26} \mathrm{Al},{ }^{21} \mathrm{Ne}$, and ${ }^{14} \mathrm{C}$. Given the long half-life of ${ }^{10} \mathrm{C}$ ' anu the increasingly low analytical backgrounds that can be realized (Wilcken et al 20. 9), it is now possible to analyse samples covering a wide range of temporal sett ngs, including historic times (Schaefer et al. 2009). The rate at which cosmogenic nuclı' 'es are produced is extremely low - a couple of atoms per gram of rock per year (Borchers et al. 2016) - and the rapid attenuation of cosmic radiation with depth (Fig. 6) confines the production of cosmogenic nuclides to the upper few meters of the crust, the production rate decreasing roughly exponentially with depth (Argento et al. 2015a, b). Production rates of cosmogenic nuclides are mainly a function of geomagnetic latitude and altitude above sea level (Balco et al. 2008; Lifton et al. 2014). Site-specific production rates are also subject to several other factors, such as the geometry of the surrounding topography, which shields part of the incoming cosmic radiation (Dunne et al. 1999; Codilean 2006; DiBiase 2018). 
Fig. 6: Production rates of in situ ${ }^{10}$ Be in quartz as a function of depth. Note how the production rate by high-energy neutrons (spallation), although substantially higher at the surface than that by muons, attenuates more quickly with depth. This means that whereas in the upper few metres of rock, spallation reactions are dominant, at greater depths, muons account for the production of virtually all ${ }^{10} \mathrm{Be}$. Modified from Dunai (2010) and based on Heisinger et al. $(2002 a, b)$.

The application of cosmogenic nuclides to the study of sedimentary archives is based on two principles: (i) cosmogenic nuclide concentrations are directly proportional to the exposure time to cosmic radiation - i.e., nuclides accumulate in surficial deposits over time such that their concentration will be directly relatea nr: only to the exposure age but also to the rate at which the surface is eroding (Cr, ng'r and Schaller 2014), and (ii) two radionuclides will be produced at a fixed ricic sut will decay at different rates dictated by their half-lives (Granger and Smith $2 v_{\imath}$ - Granger and Muzikar 2001) - i.e., when previously exposed river sediment be 0 temporarily or permanently shielded from cosmic radiation, the differential r.a ay of two cosmogenic radionuclides results in a change in the ratio of these nuclides $l_{\text {. }}$ nroportion to the duration of burial. Given that the majority of cosmogenic nuclide studies have used ${ }^{10} \mathrm{Be}$ for exposure dating and

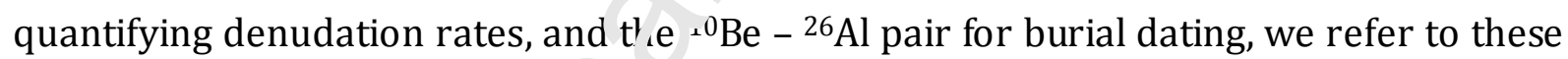
nuclides in the following sectic ns. riowever, the principles discussed below apply to all in-situ produced cosmogen: $\sim$ n - clides.

\subsubsection{Quantifying basin wiG ? denudation rates}

As a parcel of rock or si diment is brought toward the surface by erosion on a hillslope, its ${ }^{10} \mathrm{Be}$ concentration $(N)$ increases at a rate that depends mainly on the rate of erosion $(\varepsilon)$, and the ${ }^{10} \mathrm{Be}$ surface production rate $(P(0))$ at that locality. The temporal evolution of the ${ }^{10} \mathrm{Be}$ concentration in this parcel is accurately described by (Lal 1991; Dunai 2010):

$N(z, t)=\sum_{i=1}^{n} \frac{P(0)_{i}}{\lambda+\rho \varepsilon / \Lambda_{i}} e^{-\rho\left(z_{o}-\varepsilon t\right) / \Lambda_{i}\left[1-e^{-\left(\lambda+\rho \varepsilon / \Lambda_{i}\right) t}\right]}$

where $\lambda$ is the ${ }^{10} \mathrm{Be}$ decay constant, $z_{o}$ is the initial depth beneath the surface $[\mathrm{cm}], t$ is exposure time $[\mathrm{yr}], \rho$ is the density of the eroded material $\left[\mathrm{g} \cdot \mathrm{cm}^{-3}\right]$ and $P(0)_{i}$ and $\Lambda_{i}$ are 
the surface ${ }^{10} \mathrm{Be}$ production rate [atoms. $\mathrm{g}^{-1} \cdot \mathrm{yr}^{-1}$ ] and the mean cosmic ray attenuation length with depth [g.cm-2] for a given production pathway, respectively (Granger and Smith 2000). Over sufficiently long periods of time $\left(T \gg 1 /\left(\lambda+\rho \varepsilon / \Lambda_{i}\right)\right)$, the ${ }^{10} \mathrm{Be}$ concentration in the parcel is no longer time dependent, rather it is determined by the erosion rate alone (Fig 7). Under these steady-state conditions, equation (4) reduces to:

$N=\sum_{i=1}^{n} \frac{P(0)_{i}}{\lambda+\rho \varepsilon / \Lambda_{i}}$

One of the most important prerequisites for equation (5) ic be valid is that erosion is continuous, occurring by grain-by-grain removal of mate ial, and that it is not episodic, occurring by the spontaneous removal of discrete blocl s of varying thicknesses.

Fig. 7: Temporal evolution of the surface ${ }^{10}$ Be conc ' ration under continuous (left) and episodic (right) erosion regimes. Under contin uc $\boldsymbol{A}^{\mathrm{r}}$ erosion the surface ${ }^{10}$ Be concentration reaches a constant value (red curve), and th amount of ${ }^{10}$ Be produced by cosmic rays will equal the amount removed by erosion . $r$ d radioactive decay. Episodic erosion processes, on the other hand, remove discrete hlocks of rock or sediment. The truncation of the exponentially decreasing ${ }^{10} \mathrm{Be}$ dek $h * \cdot$ ffile (blue curve) means that a constant surface ${ }^{10}$ Be concentration will not be r.acr. 2 ; instead this will fluctuate with time as the amount of ${ }^{10} \mathrm{Be}$ produced will never $\mathrm{m}_{\mathrm{L}^{+}}{ }^{+} \mathrm{ch}$ the amount removed by erosion. (1) If the removal of blocks is periodic (time betr.oer. spalling events $T_{i}=$ constant $=T$ ) and the size of the blocks is uniform ( $w$ consta ${ }^{2}$ ) the ${ }^{10}$ Be concentration will fluctuate around a long-term average value (Small et al. 1997). (2) If the removal of blocks follows a Poisson process, with both $T_{i}$ and $w$ being stochastic variables, the average ${ }^{10}$ Be concentration and its spread will depend on $T$ (the average time between spalling events) and the probability distribution of w (Muzikar 2008, 2009).

When the parcel of rock or sediment reaches the surface, it is transported via hillslope processes to the fluvial system, where it mixes with sediment from other parts of the contributing basin. Thus, rivers act not only as agents of erosion but also as in tegrators, collecting sediment from all parts of the basin in an amount that is proportional to their denudation rates such that the sediment will contain an average concentration of ${ }^{10} \mathrm{Be}$ at the outlet of the basin that is a measure of the basin's mean denudation rate. If (i) the 
volume of sediment contributed by different parts of the basin is proportional to the area of those parts, and (ii) the averaging timescale of denudation in the basin is short relative to the ${ }^{10} \mathrm{Be}$ half-life (or that of the nuclide of choice), and (iii) the timescale of sediment transport and storage is negligible as compared to the timescale of denudation (Brown et al. 1995; Bierman and Steig 1996; Granger et al. 1996), then equation (5) can also be used to calculate basin-wide average denudation rates $(\bar{e})$ from the average ${ }^{10} \mathrm{Be}$ concentration of the mix of sediment leaving a basin $(\bar{N})$.

Cosmogenic nuclide-based denudation rates have now been determined in more than 4000 basins world-wide (Codilean et al. 2018), contribuing substantially to our understanding of the relative effects of climate and topog $\urcorner n+y$ on denudation rates in a wide range of tectonic settings (Granger and Schall 21 2014). However, there is still a paucity of data from landscapes situated at the axiremes of denudation-rate and topography spectra, confounding studies aimirg on infer global-scale trends from compilations of ${ }^{10} \mathrm{Be}$-based denudation rates ( $\mathrm{T}$ o tenga and Bierman 2011; Willenbring et al. 2013; Harel et al. 2016). At one $\sim$ a of the spectrum are the low-gradient arid landscapes that occupy large portions ‘' Gondwana remnants such as Australia, Africa, and South America. Here lithology pin v a key role in controlling landform morphology and thus the styles and rates o. 'il slope evolution, and therefore also cosmogenic nuclide inventories (Cazes et á: 2020). The low gradients also mean that sediment may spend prolonged periods o: thı e (on the order of $10^{5-10^{6}}$ years) within hillslope soils (Struck et al. 2018a; $\mathrm{M}^{n} \mathrm{k}_{\mathrm{H}}{ }^{\prime}$ 'ela et al. 2019) or moving through the fluvial network (Struck et al. 2018L, I ' n cases may lead to increased ${ }^{10} \mathrm{Be}$ inventories and thus underestimated denu ${ }^{\text {J-cion }}$ rates, and potentially to the alteration of any source area environmental signals travelling from source to sink (Fülöp et al. in press). At the other end of the spectrum are the steep (and often wet) tectonically active landscapes where episodic erosion processes such as landsliding are the most important means of delivering sediment from hillslopes to the drainage network (Korup et al. 2010).

Episodic erosion processes remove discrete blocks of rock or sediment, and the truncation of the exponentially decreasing ${ }^{10} \mathrm{Be}$ depth-profile (Fig. 6) means that a constant surface ${ }^{10} \mathrm{Be}$ concentration will not be reached (Fig. 7). Instead the ${ }^{10} \mathrm{Be}$ concentration will follow a time independent, equilibrium statistical distribution $\left(f_{e q}(N)\right)$ that depends on the magnitude distribution and the recurrence interval of the 
episodic erosion process (Muzikar 2008, 2009, 2019). For this equilibrium condition, the average ${ }^{10} \mathrm{Be}$ concentration on a hillslope $(\langle N\rangle)$ is given by Muzikar (2009):

$\langle N\rangle=\int_{0}^{\infty} d N f_{e q}(N) N=\frac{P(0)}{\lambda+1 / T\left(1-\overline{e^{-\rho w / \Lambda}}\right)}$

where $T$ is the average time between landslides (or other episodic spalling events) and $w$ is the thickness of the removed block, a stochastic variable governed by a distribution $g(w)$. The notation $\overline{e^{-\rho w / \Lambda}}$ stands for an average over the thickness distribution $g(w)$ :

$\overline{e^{-\rho w / \Lambda}}=\int_{0}^{\infty} d w g(w) e^{-\rho w / \Lambda}$

The mean square fluctuation in $N$ (i.e., the likely $s_{\uparrow}{ }^{n_{0}} \mathrm{~d}$ in ${ }^{10} \mathrm{Be}$ concentrations) is given by Muzikar (2009):

$\left\langle(\Delta N)^{2}\right\rangle=\left\langle N^{2}\right\rangle-\langle N\rangle^{2}=\langle N\rangle\left(\frac{2 P(0) i}{1+2 T \lambda-e^{-2 \rho w} / .}=\langle N\rangle\right)$

The brackets \langle\rangle in equations $(\epsilon$ ) anu (8) stand for an average over time. Therefore, $\langle N\rangle$ and $\left\langle(\Delta N)^{2}\right\rangle$ represent the a'erase ${ }^{10} \mathrm{Be}$ concentration and the likely spread in this concentration, respective:r. ot served on a hillslope, or at the outlet of a catchment, over a period of time. Fqu atio is (6) and (8) can be applied to a wide range of episodic surface erosion scenaric; that follow a Poisson process (for more extreme scenarios see Muzikar 2019). The essential point is that if the magnitude-frequency distribution of landslides in a given catchment is known independently, equations (6) and (8) can be used to determine the long-term average and the spread in ${ }^{10} \mathrm{Be}$ concentrations in the sediment leaving this catchment. Conversely, if the long-term average and the spread in ${ }^{10} \mathrm{Be}$ concentrations in the exported sediment are known, equations (6) and (8) can also be applied to gain insights to links with the size distribution of landslides, and their recurrence intervals.

Improvements in sample measurement (Wilcken et al. 2019) and enhanced sample throughput will enable the large number of sample counts necessary to go beyond mean denudation rates of large catchments in the future. Delving deeper into the processes 
controlling sediment production and sediment transport at the catchment scale could be achieved by looking at, for example, single-clast distributions of cosmogenic nuclide concentrations (Codilean et al. 2008; McPhillips et al. 2014; Carretier et al. 2019; Muzikar 2019; Prush and Oskin 2020). The applications of meteoric ${ }^{10} \mathrm{Be}$ (e.g. Dannhaus et al. 2018) and applications of in-situ produced ${ }^{10} \mathrm{Be}$ in minerals other than quartz (e.g. Moore and Granger 2019) will also extend the applicability of basin-wide denudation rate studies to non-quartz bearing lithologies.

\subsubsection{Dating of sedimentary deposits and quantifying palaeo denudation rates}

As shown in Fig. 6, cosmogenic nuclide production rates recı ?ase roughly exponentially with depth, and this property has been exploited as a r.1ea is of dating the abandonment of fluvial deposits (Anderson et al. 1996; Repka et a. 19y7). The principle behind this application is illustrated in Fig. 8, and is explainec as $\dagger$ Jllows. Clasts building up a fluvial deposit arrive at the site with varying cosmr ranic nuclide concentrations (fuzzy blue band in Fig. 8) but are assumed to have let: emplaced with uniform distribution of nuclide concentrations with depth $\left.{ }^{10} \mathrm{~B} 2(\mathrm{in})\right)$. Due to the exponential decrease in production rate with depth, subsec'rent ac umulation of cosmogenic nuclides will result in a shift from the original unif $\Omega \eta$ uistribution to one following an exponentially decaying curve. Mean nuclide c s. ${ }^{\tau} \epsilon_{11}$ crations measured from amalgamated clasts taken at the surface $\left({ }^{10} \mathrm{Be}(s 1)\right)$ and subsurface $\left({ }^{10} \mathrm{Be}(s 2)\right)$ of the deposit will differ from each other in proportion to the al ount of time elapsed since terrace abandonment. Thus, provided that the sub: urfc ce sample is deep enough relative to the mean cosmic ray attenuation length (see above), the depositional age of the terrace is simply given by ${ }^{10} B e(s 1)-{ }^{10} B e(s 2)$. In addition, the basin-wide denudation rate the time of terrace emplacement (i.e., palaeo-denudation rate) can also be calculated using ${ }^{10} B e(s 2)$. The technique relies on a couple of assumptions (Anderson et al., 1996): (i) clasts are emplaced with uniform distribution of nuclide concentrations with depth, (ii) the deposit has not been disturbed or mixed since emplacement (e.g. by bioturbation, cryoturbation, pedogenesis, etc.), and (iii) the terrace surface has not been modified, either by subsequent erosion or deposition, since emplacement. In most cases these assumptions are impossible to test a priori, and a successful application of the technique involves the collection of several samples (e.g., $n>10$ ) from a depth profile that is a couple of meters in depth, and the use of numerical approaches that allow for 
complicating factors such as vertical mixing post deposition, varying inheritance with depth, erosion of the terrace surface, etc., to be explicitly considered (Hidy et al. 2010).

Fig. 8: Principles of using cosmogenic nuclide depth profiles for dating fluvial deposits (modified after Anderson et al. 1996). See text for more details.

Deposits can also be dated using a pair of cosmogenic radionuclides (or a pair consisting of one radionuclide and one stable nuclide) by exploiting the property that these nuclides are produced at a fixed ratio but have different half-lives (Fig. 9), as long as the

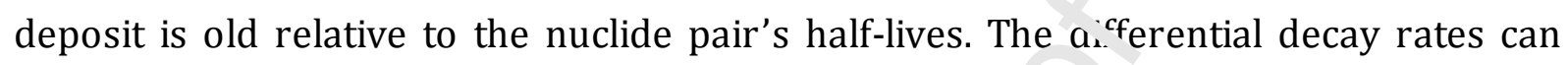
then be used to infer the time elapsed since burial (Gral ser and Smith 2000; Granger and Muzikar 2001). The most common nuclide pair $u^{-\epsilon^{+}}$ir burial dating is ${ }^{26} \mathrm{Al}$ and ${ }^{10} \mathrm{Be}$,

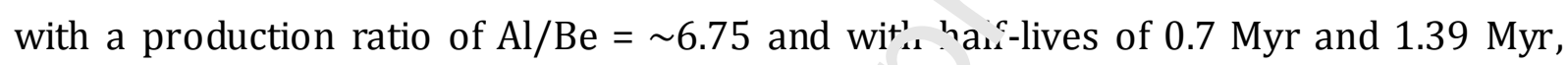
respectively. Upon burial and cessation of nuclide p roduction, the differential decay of the two nuclides results in a change in the rat o of these nuclides (Fig. 9A), and the burial age can be calculated as:

$t_{b}=-\ln \left(\frac{R_{A B}\left(t_{b}\right)}{R_{A B}\left(t_{0}\right)}\right) /\left(\lambda_{A}-\lambda_{B}\right)$

where $t_{b}$ is the burial duratio- (years) , $\lambda_{A}$ and $\lambda_{B}$ are the half-lives of the two nuclides, and $R_{A B}\left(t_{b}\right)$ and $R_{A B}\left(t_{0}\right)$ art the measured and production ratios of the nuclide pair, respectively (Fig 9h), 'i he sseful age range of a burial dating nuclide pair is set by the half-lives of the two nur.ides; at some point the nuclide with the shorter half-life attains a concentration where measurement is no longer possible. Under ideal conditions, the useful range of the ${ }^{26} \mathrm{Al}$ and ${ }^{10} \mathrm{Be}$ pair is between 0.5 - $6 \mathrm{Myr}$ (Granger 2006). This range can be extended, however by introducing a third nuclide, ${ }^{21} \mathrm{Ne}$, that is stable. Because ${ }^{10} \mathrm{Be}$ has a half-life that is nearly double that of ${ }^{26} \mathrm{Al}$, and because ${ }^{10} \mathrm{Be}$ can be measured more precisely at low concentrations than ${ }^{26} \mathrm{Al}$, the useful range of the ${ }^{10} \mathrm{Be}-{ }^{21} \mathrm{Ne}$ burial dating pair is more than double that of the ${ }^{26} \mathrm{Al}-{ }^{10} \mathrm{Be}$ pair. Thus, ${ }^{10} \mathrm{Be}-{ }^{21} \mathrm{Ne}$ burial dating should be applicable even for deposits of Miocene age (Balco and Shuster 2009).

Fig. 9: Diagrams illustrating the principles of burial dating. (A) Fast and complete burial. During exposure to cosmic radiation the ratio of a nuclide pair (such as ${ }^{26} \mathrm{Al}$ and ${ }^{10} \mathrm{Be}$ ) 
evolves such that the sample will plot inside the erosion island. Upon burial and cessation of nuclide production, the ratio of the nuclide pair will start to decrease following the path indicated by the red arrow. This ratio is proportional to the duration of burial and thus can be used to calculate the burial age of the sample. The position of the sample in the Al/Be vs. Be space also provides information on the pre-burial denudation rate. (B) Incomplete burial with variable inheritance. Samples that were subject to a simple and complete burial history will rotate along trends indicated by the blue lines. Samples with variable inheritance (red circles) but similar post burial production will evolve on displaced lines (red lines), parallel to the trends indicated by the blue lines. The slope of the trend defined by the samples is used to calculate the burial age. Modified fro.? Dunai (2010) and based on Granger and Muzikar (2001) and Balco and Rovey (2008;

The method outlined above is ideal for dating in sedimentary deposits or cave sediments. However, in many cases, post-burial rru uction of cosmogenic nuclides due to muons or as a result of intervals of re-exp 's $2 \mathrm{r} ?$, must be taken into account (Fig. 9B). The variation in measured ${ }^{26} \mathrm{Al}$ and ${ }^{1 n}=2$ inr ${ }^{21} \mathrm{Ne}$ and ${ }^{10} \mathrm{Be}$ ) in a group of samples collected from the same stratigraphic la, er can be used to solve explicitly for the postburial component that will be commun among the samples. This method, called isochron burial dating (Balco and Rovey 2,0 ) was successfully applied to dating of poorly preserved fluvial terraces as oi.' as $\sim 4$ Myr (Erlanger et al. 2012).

\section{Organic geochemi-al proxies for terrestrial habitat change}

As vegetation adapt to rive nate fluctuations or is modified or replaced through human activities, the molecu'ar composition of plant litter and soil organic matter exported towards a depositional environmental archive changes accordingly. Molecules of known biological origin (biomarkers) or their chemical properties such as the carbon isotope ratio $\left({ }^{13} \mathrm{C} /{ }^{12} \mathrm{C}\right)$ can be used to reconstruct such changes even if macro- or microscopically identifiable fossil material is absent due to continuous particle break-up during transport. The aboveground vegetation typically represents the smaller part of the terrestrial organic carbon pool. In undisturbed ecosystems, degrading plant litter and belowground biomass consisting of root tissue represent the larger part, in fact, two-thirds of the global terrestrial organic carbon is stored in soils (Post et al. 1982). The dynamics of the soil carbon pool can differ substantially in their response to environmental change, with slow build-up of the soil carbon pool resulting in lead-lag 
relationships with climatic parameters or vegetation, for example. In lacustrine catchments, lake level fluctuations can introduce an additional level of complexity. Changes in lake surface area inversely affect the surface area occupied by the surrounding terrestrial habitats and modify the fluxes of terrestrial organic matter towards the recording site. For example, organic matter may be supplied directly through surface run-off from surrounding slopes during lake-level highstands or be trapped in low-lying wetlands during lake-level lowstands, depending on basin morphology and lake morphometry. Finally, land-use change fundamentally alters the biome in the catchment of an environmental archive with regard to organic matter sources and fluxes. Land clearance for farming may renlas the natural vegetation entirely and modify the soil pool. Slash-and-burn clearar ${ }^{-e}$; roduces large amounts of charred material and combustion products while sett'e. ner ts and animal husbandry can

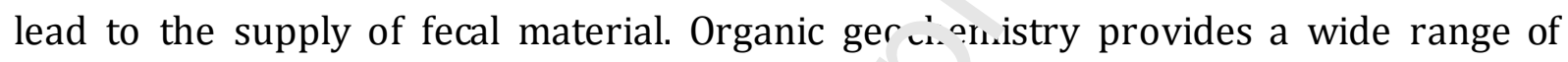
biogeochemical tools to identify both natural $\mathrm{nn}_{\mathrm{n}}$ anthropogenic alteration of the terrestrial habitats in the catchment of a der $0^{\prime}, 1^{\prime}$ onal environmental archive, revealing changes in vegetation, soil stability, fire .. ' $q_{\llcorner}$. ency and farming.

\subsection{Molecular indicators for vegetation cilange}

Waxes are major constituents of t'ie protective outer surface layers of land plants, most prominently of the cuticular lay eı ר ז ıeaves. Leaf waxes consist of esters of long-chain $n$ fatty acids and $n$-alcohols as welı as $n$-alkanes and ketones, aldehydes, i.e. alkyl lipids (Eglinton and Hamilton 19,7). The $n$-fatty acids and $n$-alcohols of leaf waxes predominantly are eve 1-nu mbered carbon chains in the range of 24 to 38 carbon atoms while $n$-alkanes are don inated by odd-numbered carbon chains of 23-37 carbon atoms. Notably, the length of the alkyl lipid carbon chains preferentially biosynthesized by plants differs between plant species. For example, the dominant $n$-alkane in leaf wax of the common beech (Fagus sylvatica) is the $C_{27} n$-alkane while it is the $C_{29} n$-alkane in oak (Quercus) and the $C_{31} n$-alkane in grass species growing at the same location (Holtvoeth et al. 2016, Fig. 10).

Fig. 10: Comparison of chain-length distributions of $n$-fatty acids and n-alkanes in oak and beech leaf litter and in grasses with those of the underlying topsoils and of sediment from the Lake Ohrid Basin, Albania/North Macedonia (modified from Holtvoeth et al. 2016). The intramountainous basin features a high altitude gradient and steep slopes, with the lower altitudes being dominated by oaks and shrubs and the higher altitudes by beech forests 
with patchy grassy undergrowth. Note the maximum amount of the $C_{31} n$-alkane in the topsoil from the beech forest, which results from higher concentrations of $n$-alkanes in grasses compared to beech leaves and the fact that decaying grass is more likely to being directly incorporated into the topsoil whereas the leaves are mobile, altogether leading to an over-representation of the grass-derived n-alkane. Also note the generally higher proportions of $C_{22}$ and $C_{24} n$-fatty acid in the topsoils compared to the leaf wax-derived $C_{26}$ to $C_{32} n$-fatty acids in the leaf litter and grass samples. These compounds are assumed to derive from suberin, a protective bio-polyester found mainly in root tissue, hence, representing belowground biomass. The sediment shown here represents the dry period of the $8.2 \mathrm{ka}$ event that led to vegetation recession and destabui-ation of soils. The higher than normal amounts of the suberin-derived $C_{22}$ and $C_{24} n-$, rtt acids reflect the increased soil erosion rates during this event.

Considering the vast number of plant species anc. the narrow range of dominant chain lengths typically biosynthesized, it is highly ur:il ely that average alkyl lipid chain-length distributions can be assigned to a specific e e $e_{1}$ nember type of vegetation within the catchment of an environmental ar niv - unless biodiversity is extremely low, i.e. dominated by single species. Howe rer, shil is in the predominant carbon chain lengths of alkyl lipids observed in a depr si nnal archive will nevertheless be indicative of vegetation changes or changes 1 -ryanic matter fluxes within the catchment and can be plotted as variability of the arage chain length (ACL):

$$
\mathrm{ACL}=\Sigma\left(\mathrm{C}_{\mathrm{n}} \times \mathrm{n}\right) / \mathrm{S}\left(\mathrm{C}_{\mathrm{r}}\right)
$$

$n$-Alkanes have become the prime targets in biomarker-based palaeoenvironmental investigations as they do not contain functional groups, which increases their preservation potential in depositional archives relative to $n$-fatty acids and $n$-alcohols and minimizes lipid extract preparation for analysis (no derivatization of functional groups). The ratio of supposedly grass-derived $C_{31}$ and $C_{33} n$-alkanes over $C_{27}$ and $C_{29} n$ alkanes assumed to dominate leaf waxes of trees is frequently used as indicator of shifts from forests to more open, grassy vegetation and vice-versa. Although not statistically sound on a globally applicable level (Bush and McInerney 2013), this approach appears suitable for vegetation reconstructions on regional scale, in particular, if the dominant species involved can be narrowed down and biogeochemical fingerprinting of the main 
leaf wax sources, i.e. vegetation and soils, provides a local modern analogue calibr ation (e.g. Schwark et al. 2002; Bliedtner et al. 2018). In contrast to the non-specific long-chain ( $\geq 25) n$-alkanes, the mid-chain $\mathrm{C}_{23} n$-alkane is a rather reliable biomarker for Sphagnum peat mosses (Bush and McInerney 2013). Another more specific alkyl lipid biomarker is the branched $\mathrm{C}_{29}$ alcohol nonacosan-10-ol, a prominent compound in leaf waxes of conifers (Matas et al. 2003).

In tropical and subtropical settings, compound-specific stable isotope analysis (CSIA) of leaf-wax derived alkyl lipids can indicate changes in the openness of the vegetation and the relative proportions of trees and grasses. Tropical grasses are typically $\mathrm{C}_{4}$ plants, named after the first photosynthetic metabolic product consis ing of four carbon atoms, while most other higher land plants are $\mathrm{C}_{3}$ plants. $\mathrm{N}_{2} \mathrm{ta}^{2}, \mathrm{ly}, \mathrm{C}_{4}$ plants incorporate significantly higher proportions of the heavy carbon ${ }^{\text {so }} \mathrm{o}^{+} \mathrm{spe}\left({ }^{13} \mathrm{C}\right)$ into their biomass than $C_{3}$ plants that strongly discriminate agains ${ }^{+}{ }^{2} r$. (O'Leary 1981). As a result, the ${ }^{13} \mathrm{C} /{ }^{12} \mathrm{C}$ stable carbon isotope ratio of $\mathrm{C}_{4}$ grass-der. differs from those of $C_{3}$ plants such as tropici $\left(t_{1} \epsilon\right.$ ?s and is expressed as the $\delta^{13} C$ value of a compound relative to a standard:

$\delta^{13} C=\left(\frac{\left({ }_{0}^{13} C /{ }_{0}^{12} C\right)_{\text {sample }}}{\left({ }_{0}^{13} C /{ }_{0}^{12} C\right)_{\text {standard }}}-1\right) * 10^{n} \eta^{c}$

Compound-specific $\delta^{13} \mathrm{C} \quad \mathrm{V}$ lues have been successfully applied in numerous palaeoenvironmental studies in tropical settings to reconstruct shifts of $\mathrm{C}_{3}$ and $\mathrm{C}_{4}$ vegetation zones (e g. Iua ig et al. 2001; Tierney et al. 2010; Sinninghe Damsté et al. 2011). Although $n$-alkar es are preferentially analysed for ease of sample treatment, $n$ fatty acids and $n$-alcohols can also be targeted, particularly in recent/Quaternary sediments where they are often present in significantly higher abundance than $n$ alkanes (Hughen et al. 2004; Russell et al. 2009).

Fig. 11: A: Histograms of stable carbon isotope distributions of C3 and C4 plant biomass (from Tipple and Pagani 2007 using data by Cerling and Harris (1999) and B: Reconstruction of the decrease in C4 grass-dominated vegetation in the catchment of Lake Challa (E Africa) since the Last Glacial using compound-specific stable carbon isotope values of the $C_{31} n$-alkane in the lake sediments (modified from Sinninghe Damste et al. 
2011). Note that maize is a C4 plant and its introduction as agricultural produce outside the tropics can be reconstructed through an equivalent approach.

In analogy to wax-derived alkyl lipids, vegetation changes can also be seen in changing relative amounts of terpenoids that derive from resin, bark and leaf tissue of higher plants (Langenheim 1994). Deciduous trees (angiosperms) produce pentacyclic triterpenoids while conifers (gymnosperms) produce tricyclic diterpenoids (Otto and Simpson 2005; Diefendorf et al. 2012; Giri et al. 2015). Changing ratios of di- and triterpenoids have therefore been used as palaeovegetation proxies (Bechtel et al. 2003; Schouten et al. 2007). Both the fact that deciduous wes and conifers produce substantially different amounts of terpenoids relative $t$, th ?ir total biomass and the different preservation potential of di- and trit rpt noids introduce significant uncertainty in terpenoid-based reconstructions of he vegetation, with a likely bias towards conifers (Giri et al. 2015). Still, the va ' $7 b$ ity of di- and triterpenoid ratios supports other proxy data sensitive to veget - : $n$ n change from organic geochemical or palynological analyses. In recent sediment, , cianging proportions of the triterpenoids $\alpha$ - and $\beta$-amyrin also indicate char ses in the sources of terrigenous plant matter (Chávez-Lara et al. 2018), with $\alpha$ `myrin occurring in higher amounts in plant resins and resinous tissue of common $S^{\prime} \cdot \mathbf{b}$. $\urcorner$ pical dry forest species Bursera and Protium, for example (Hernández-Vázquez $\in$ tà. z012).

Lignin phenols, finally, prov Je another established biomarker-based tool to detect vegetation changes. Lig. in, after cellulose the second-most abundant structural macromolecule in high 'r k c nd plant tissue, contains a range of phenolic alcohols of the syringyl, cinnamyl and ranillyl group. Crucially, these phenols are incorporated into lignin in distinctly different proportions, depending on tissue type (woody vs. nonwoody) and the taxonomic group of vascular plants (angiosperms vs. gymnosperms). Ratios of syringyl over vanillyl (S/V) and cinnamyl over vanillyl alcohol (C/V) can therefore be used to reconstruct, for example, changes in the supply of plant matter from conifers (gymnopsperms) or grasslands within the catchment of a depositional archive (Hedges and Mann 1979; Fuhrmann et al. 2003; Hyodo et al. 2017) or to trace the spatial distribution of terrestrial organic matter in marine sediments (Smith et al. 2012; Seki et al. 2014). 


\subsection{Molecular indicators for the supply of soil organic matter}

To date, there is no single geochemical proxy to reliably quantify the amount of soil organic matter buried in a sedimentary record. This is due to the large molecular overlap between plant litter and soil organic matter, resulting from a continuum of degradation stages. Very few biomarkers have been found that exclusively represent belowground plant biomass, i.e. root material, one of them being $\alpha, \omega$-alkanedioic acids, or diacids, that derive from the protective polyester suberin in root tissue (MendezMillan et al. 2011; Ji et al. 2015). Suberin consists of alternating layers of aromatic and aliphatic compounds ( $n$-fatty acids, $n$-alcohols, $\omega$-hydroxy acids, $\alpha, \omega$-diacids), with characteristic chains of 22 or 24 carbon atoms in the aliph=-ic :ayer (Molina et al. 2006; Graca and Santos 2007). The $\mathrm{C}_{22}$ and $\mathrm{C}_{24} \omega$-hydroxy nas are major compounds of suberin but can also derive from other tissue types, 1 aving the mid-chain diacids as the only reliable indicators for root material suppl $v$. $\checkmark$ 'hile root-derived lipids are not quantitatively representative for belowground b; Jmais or soil organic matter buried in a sediment, variable proportions of $\mathrm{C}_{22}$ and $C_{1}+$ a kyl lipids relative to long-chain $\left(>\mathrm{C}_{24}\right)$ leaf wax-derived compounds indicate ih $_{\mathrm{i}} \mathrm{ngt}_{\mathrm{s}} \mathrm{in}$ the terrestrial carbon pool dynamics (Holtvoeth et al. 2016; Holtvoeth et al. ¿217). Compound-specific radiocarbon analysis (CSRA) of alkyl lipids can also reveal c'anges in the supply of pre-aged, i.e. soil-derived material through age offsets with th s',ediment age (Smittenberg et al. 2006; Gierga et al. 2016). Since each alkyl lipid $f$ ac:ion represents a mixture of fresh and fossil compounds this approach needs to be co.nbined with other proxies sensitive to soil supply in order to assess the relative am ount of fossil compounds, thus, enabling an estimation of terrestrial residence $t_{1 .}$.

Biomarkers from strains of soil bacteria provide an alternative to root-derived compounds for reconstructing the variable input of soil organic matter towards a depositional archive. A series of branched glycerol-dibiphanyl-glycerol tetraethers (brGDGTs) are cell membrane lipids of anaerobic bacteria in soils. A number of structurally related isoprenoidal GDGTs (iGDGTs), on the other hand, is exclusively produced by aquatic Thaumarchaeota. The ratio of specific branched and isoprenoidal GDGTs, the so-called BIT index, was therefore defined to reflect the changing proportions of soil organic matter supply as represented by the bacterial lipids relative to aquatic production (Hopmans et al. 2004; Weijers et al. 2006). The BIT index has been applied successfully in reconstructions of environmental change on a range of time 
scales (Cao et al. 2017; Mayser et al. 2017) and studies tracking the dispersal of terrestrial organic matter in the marine realm using marine surface sediments off major point sources, i.e. rivers with large terrestrial catchments (Smith et al. 2012; Seki et al. 2014). The approach assumes that brGDGTs are representative of soil organic matter and that iGDGT production in the waterbody does not vary to the same extent as soil organic matter supply. It appears, however, that Thaumarchaeota thrive in low-nutrient settings (Konneke et al. 2014), i.e. iGDGT production may be lower under eutrophic conditions and bias the BIT index towards seemingly increased soil organic matter input. In depositional settings with persistently high terrestrial input such as smaller lake basins, BIT value variability may thus be driven hv :GDGT production under variable nutrient levels (Smith et al. 2012), allowing for a. a'iernative interpretation of the BIT index as proxy for a changing nutrient regin. (' anagiotopoulos et al. 2020). Some brGDGTs have been found to also be produc $-\dot{u}$ : $\eta$ ihe marine water column (Zell et al. 2015) and in lake water (Weber et al. 2015; requiring a local calibration or complementary proxy data.

\subsection{Bulk organic matter characteristi $s \mathrm{i}$ 'dicating soil organic matter supply}

During microbial breakdown, soil organic matter typically becomes enriched in ${ }^{13} \mathrm{C}$ relative to ${ }^{12} \mathrm{C}$ and in total nitros, es $\left(\mathrm{N}_{\text {tot }}\right)$ relative to organic carbon $\left(\mathrm{C}_{\mathrm{org}}\right)$ to various degrees, i.e. bulk $\delta^{13} \mathrm{C}_{\text {org }}$ values if soil organic matter increase while $\mathrm{C}_{\text {org }} / \mathrm{N}_{\text {tot }}$ ratios decrease. Both bulk $\delta^{13} \mathrm{C}_{\text {org }} \mathrm{Va}_{\mathrm{a}}$ 'yes and $\mathrm{C}_{\text {org }} / \mathrm{N}_{\text {tot }}$ ratios have been popular as fast and lowcost proxies to assess the slative proportions of aquatic and terrigenous organic matter in sediments, typically 'usir g two end-member values for aquatic and terrestrial plant biomass. However, due $\mathrm{t}$ ) the diagenetic continuum from plant litter to heavily degraded soil organic matter a single terrestrial end-member does not exist. In fact, degradation of terrigenous organic matter in soils can produce a terrestrial sedimentary organic matter fraction with bulk $\delta^{13} \mathrm{C}_{\text {org }}$ values and $\mathrm{C}_{\text {org }} / \mathrm{N}_{\text {tot }}$ ratios similar to those characterizing organic matter from aquatic sources, leading to severe underestimation of terrestrial organic matter burial and erroneous carbon budgets (Holtvoeth et al. 2005). Nevertheless, as bulk $\delta^{13} C_{\text {org }}$ values and $\mathrm{C}_{\mathrm{org}} / \mathrm{N}_{\text {tot }}$ ratios of sediments with high allochthonous organic matter input can also be determined by changes in terrestrial organic matter quality rather than quantity, these proxies can help identifying phases of enhanced soil erosion and associated soil organic matter supply, in particular, if bulk data of potential soil sources is available. In metal-rich soils such as tropical and 
subtropical lateritic soils, organic compounds can be bound firmly to the clay fraction through coupling to the metal oxyhydroxides that cover the clay mineral surfaces. Such stabilized organic matter can be detected by Rock-Eval pyrolysis as it is broken up into volatile compounds at significantly higher temperature compared to non-bound soil organic matter (Holtvoeth et al. 2005).

\section{Climate forcing versus land-use change}

Untangling climate versus anthropogenic induced landscape change is often challenging. This holds particularly true when climate change temporally coincides with the first arrival of humans at a study site and/or technological advanı sments in the society. The first step to untangle these two potential causes of la ds'ape change is to reliably establish a record of regional climate change and anthi רpr genic occupation. This can be obtained for example by means of traditional p' palaeoclimate archive, and by means of archeologica and/or historical research. Human presence in a given catchment can also be 0 : if rmed by the occurrence of cultivated pollen taxa in a depositional archive. In he Mediterranean realm, for example, the occurrence of taxa such as Juglans ( : alnut), Olea (olive), Castanea (chestnut) and Cerealia (group of herbaceous tax indicating the presence of fields) are used as widespread indicators of inc.e ts $ı$ g human activity (Mercuri et al. 2013;

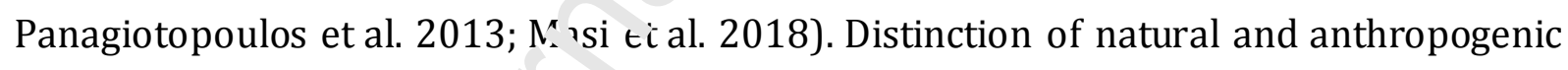
causes of landscape char $\sigma e$, as inferred from previously discussed geochemical methods, is then often has, d on the pure absence or presence of climate change, first human occupation, $c^{-} t_{t}$-h .ical advancements in the society (e.g. Rothacker et al. 2018). In some cases, the crurrence of distinct depositional features, such as colluvium deposits in central Europe (cf. section 2), are interpreted as stand-alone indicators of human land use and the erosion of bare soils (Dotterweich 2013). Land-use change for settlement and agricultural purposes is often associated with the initial clearance of the pre-existing (natural) vegetation and more or less substantial earthworks, from simple field clearance or construction of a drainage system to terracing slopes, leading to at least temporary soil destabilization and erosion. Both vegetation change and soil erosion can be recognised as such in depositional environmental archives through the application of geochemical approaches described above.

In addition, there are biogeochemical tools that identify human activity as the main driver of observed environmental change, beyond timing and rate of change. Land 
clearance is frequently associated with burning of the original vegetation, as are agricultural practices such as stubble burning. This can be seen in depositional archives as increasing amounts of charred particulate material (charcoal, black carbon) as well as molecular combustion products such as monosaccharide anhydrides (MAs) and polycyclic aromatic hydrocarbons (PAHs). The latter are produced from incomplete combustion of organic matter while the former derive from the combustion of cellulose and hemicellulose (Simoneit 2002). While PAHs and MAs are also a product of natural wild fires, an increase in the amount of PAHs beyond the natural background level likely indicates human activity (e.g. D'Anjou et al. 2012).

Some crops biosynthesize species-specific biomarkers or have a distinct isotope fingerprint and that confirms their cultivation in a catchr. ${ }^{{ }^{n}}{ }^{\prime}$, if observed in sediments. Gramineae produce a range of pentacyclic triterpero:ts (Jacob et al. 2005) of which miliacin has been successfully used as indicatr. $f_{\rho_{1}}$ the cultivation of millet in a lacustrine catchment (Jacob et al. 2008). A more rec nt major crop in many parts of the world outside the Americas is maize, which is a $C$ grass and thus produces ${ }^{13} \mathrm{C}$-enriched compounds that can be used to recons ${ }_{-1} \cdot \mathrm{IC}_{\mathrm{L}}$ its introduction in agricultural production (Tankersley et al. 2019). Human settle. ent and animal husbandry also produce large amounts of fecal material that is eas ${ }^{1} \mathrm{y}$ mobilized and exported towards a depositional archive. The presence of fecal nic ce ial is revealed by the sterols coprostanol (5 $\beta$ -

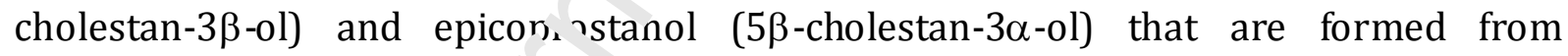
cholesterol in the intestine: oi higher mammals, including humans. In human feces, coprostanol is the mair ctt.ol while epicoprostanol is absent (Leeming et al. 1994). Concentrations of bu:h inpounds relative to other sterols can therefore be used as indicators for manurt ur sewage contamination in soils and sediments (Sherwin et al. 1993; Bull et al. 2002; Cordeiro et al. 2008) and also, therefore, in palaeodemography to indicate the establishment of larger human settlements or changes in farming practices (D'Anjou et al. 2012; White et al. 2018).

\section{Outlook}

Research on Quaternary landscape evolution is a necessity in securing soils as one of our most important resources in the light of increasing pressure by rapid climate change and land use, (section 1). Applying the reviewed methods in palaeo-records allows for the identification and understanding of feedbacks and links between climate forcing, vegetation development, and land use. The geochemical methods are typically applied to 
archives recording millennial to multi-millennial timescales (Table 1), with the exception of the geochemical analysis of varved lake sediment records (sections 2, 3.1). However, the timescale of socio-economically relevance to securing soil resources is decades or centuries. Implementing findings of Quaternary landscape evolution into policies based on micro- to macro-scale soil erosion modelling (e.g. Panagos and Katsoyiannis 2019) or global-scale land use change projections (e.g. Ostberg et al. 2018) remains a challenge. Quantifying the boundaries of (bio-)geochemical and physical processes in the Critical Zone's evolution on geological time scales, in particular at times where tipping points in the landscape's evolution are crossed, can improve the precision of modelling attempts on time scales of socio-economicallv 1 levance (section 6.1 and 6.2).

\subsection{Future directions}

Terrestrial land cover change is an essential paı of the climate system: it affects the albedo (vegetation cover), terrestrial biogr-hemical and geochemical cycles, and marine fertilisation by nutrient supply. Eaı is system models (ESM) and general circulation models (GCM) implement ve, etation and "land-use harmonization" (LUH) models to account for feedbacks bitween che climate system and the landscape (Ma et al. 2019). LUHs are thereby baser' o .: landscape models such as HYDE (Klein Goldewijk et al. 2017) or $\mathrm{KK}^{10}$ (Kaplan e. a' ${ }^{\prime}$ U09), predicting anthropogenic land cover change over time. These models are rased on population history estimates, population density, and gridded datasets of kind suitability for agriculture and pasture (Kaplan et al. 2009; Klein Goldewijk et al. :01;) and therefore inherently contain large uncertainties (Li et al. 2020). Other approa shes in modelling land-cover change on geological timescales focus on pollen-based reconstructions inferred from palynological archives such as peats and/or lake sediments. These models estimate vegetation compositions in the geological past at local catchment to regional/continental scale (e.g. Europe, temperate China), and are based on pollen reconstructions from individual depositional archives (Local Vegetation Estimates, LOVE) and multiple records with large catchments (Regional Estimates of Vegetation Abundance, REVEALS, Sugita 2007a, b; Trondman et al. 2015; Li et al. 2020). None of the aforementioned models, however, directly implements quantitative estimates of erosion, silicate weathering, and soil-biosphere evolution, i.e. processes that have a major control on landscape evolution, vegetation development and atmospheric $\mathrm{CO}_{2}$ drawdown and, thus, on the climate system. 
Quantitative models of Quaternary landscape evolution coupling forcing, feedbacks, and interaction between climate, vegetation, land use and the Critical Zone are therefore needed to improve ESMs and GCMs that focus on deca dal to centennial time scales. Such models need to be evaluated against quantitative proxy-based reconstructions of landscape change. Being capable of feeding such models with quantitative Quaternary landscape data can help to improve the accuracy of local to global scale management plans.

Developing model-proxy comparisons is of particular importance for major terrestrial carbon sinks such as tropical forests and permafrost soils (Lewis et al. 2009; Koven et al. 2011). Anthropogenic or natural deforestation in the tropics . oduces their capacity as a carbon sink while accelerated erosion mobilises old carbo: ar d prevents the recovery of tropical forests as carbon sink (Drake et al. 2019). Th wing of permafrost soils in response to climate warming could accelerate to so il erosion and thus the amount of greenhouse gases released into the atmosphere tr. $\mathrm{m}$ polar regions, which is already taking place today (Koven et al. 2011). More $\mathrm{c}$ di ntitative data in space and time about landscape evolution in these key areas $\ldots \eta$. olp to better understand processes related to tipping points in the climate system ( enton et al. 2019). Implementing information inferred from methods reviewed he s in could thus help improve catchment-, regional-, and global-scale management pla.s $t_{1}$, mitigate the impact of environmental change on decadal to centennial time scals.

\subsection{Requirements to achieve 'uture directions}

The ultimate goal of levt loping and improving quantitative models describing the Critical Zone's evolutio on geological time scales still requires significant progress in our capability to quantify biogeochemical, physical, and chemical processes in the Earth's surface. Advancements in more sophisticated geochemical analytical methods, further developments of existing methods, more inter-comparisons between the different methods (interdisciplinary approaches), and accessible data storage of quantitative Quaternary landscape change through space and time are all required, as outlined in more detail below.

More analytical techniques to better infer palaeo-erosion rates that are independent of the amount of material deposited are still required to improve our capability to quantify landscape evolution at a given time in the geological past. Erosion rates inferred from the amount of detrital matter being deposited (e.g. in colluvial deposits or a lake basin) 
are biased since not all mobilised material is stored in the analysed archive. Most promising methods for estimating palaeo-erosion rates are in-situ cosmogenic nuclides and $U$ isotopes. $U$ isotopes benefit from its applicability to fine-grained sedimentary archives, which form most continuous, highly resolved pala eoenvironmental archives. Such archives can also be used to study past weathering intensities (radiogenic isotopes) and terrestrial habitat change (organic geochemistry) simultaneously. Ideally, geochemical data is also combined with biogenic proxies (pollen) and archaeological data to reconstruct the separate evolution of past climate, vegetation, soil erosion, weathering and their relationships to human activities over the last few millennia (Bayon et al. 2019).

Databases such as for example OCTOPUS for cosmogen $n$ iclide-derived denudation rates (Codilean et al. 2018) need to be extended to st八 $、 d^{\prime}$ ferent types of data provided by the geochemical methods reviewed herein. Exr as lun of such databases will require larger datasets, both in terms of sample count and $t_{1} \cdot$ number of methods applied, and a database structure that provides fast and 22 j Combining the information obtained fr ... cifferent archives and methods also requires precise chronological alignments, wh» 1 are particularly difficult to obtain in noncontinuous sedimentary environmen -

If data from different geochemical $m$ :chods are increasingly combined there is also a need for the development of $r_{1}$ ᄀre sophisticated numerical models to analyse large sets of quantitative data. Challer res might also arise in the combination of different methods. For instance, cosmogenir $n_{\iota^{\prime}}{ }^{\prime}$ ldes and uranium isotopes provide quantitative estimates about catchment ervios l ut the numerical output is provided in loss of soil thickness per year (usually in $\mathrm{m}^{\mathrm{m}}$./yr) for cosmogenic nuclides, and as catchment residence time (usually in kyr, i.e. time between comminution and final deposition) for uranium isotopes. This task becomes even more complex when quantitative data (e.g. for catchment erosion) is compared to more semi-quantitative and qualitative data (e.g. biogeochemical cycles, terrestrial habitat change, or weathering intensities) across different sites.

\section{Conclusions}

An extensive portfolio of organic and inorganic geochemical methods have become available to study the three main elements controlling the Critical Zone's evolution over time: (a) silicate weathering and the in-situ formation of regolith (using elemental 
ratios, Sr, Hf, inorganic C isotopes), (b) erosion and transport (sediment accumulation, cosmogenic nuclides, $\mathrm{U}$ isotopes, elemental ratios), and (c) terrestrial habitats and biogeochemical cycles (organic geochemistry). Some methods are now routinely applied in Quaternary landscape research (such as for example cosmogenic nuclides, element geochemistry and organic geochemistry), while other relatively new methods show increasing evidence about their potential (e.g. metal stable and radiogenic isotopes). Developing and implementing new methods (such as $U$ isotope as quantitative measure for catchment erosion) is in particular necessary to improve our capabilities in inferring more quantitative estimates about Quaternary landscape change.

There is a strong need for further multiproxy and multidisc $\mathrm{c}_{\mathrm{F}}$ linary studies combining the methods in sedimentary archives reviewed. For is st=nce, organic geochemical methods (providing insights soil organic matter mob ll ati'n, BIT index) compared with methods used for the reconstruction of wer.uin $r_{n i n g}$ and erosion (e.g. element geochemistry, metal and radiogenic isotopes) raı provide a comprehensive picture about Critical Zone's evolution over time. Su $: \mathrm{h} r$ search has a high potential to provide better insights on internal feedback r... cri.nisms between weathering, erosion, and terrestrial habitat change that can $a m_{\uparrow}$ 'fy or mitigate the Critical Zone's response to climate forcing and land use. Such findings would also have a high significance to improving Earth System and Genæral circulation Models, since terrestrial-atmospheric interactions are an essential pa. to of vur climate system.

Table 1: Key literature for $\leadsto$ ch reviewed geochemical method. This list encompasses journal articles intro' 'lc: ing new methods and comprehensive reviews.

\begin{tabular}{|c|c|c|c|}
\hline Reference & $\begin{array}{l}\text { Reference } \\
\text { Type }\end{array}$ & Significance & \\
\hline $\begin{array}{l}\text { Dreibrodt et } \\
\text { al. (2010) }\end{array}$ & Review & $\begin{array}{l}\text { Review about the potential and limitations using geochronolgical } \\
\text { and classical sedimentary information from continuous and } \\
\text { discontinuous archives displayed in Fig. } 1 .\end{array}$ & \multirow{2}{*}{ 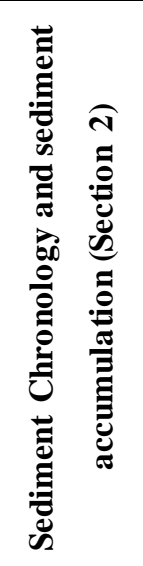 } \\
\hline $\begin{array}{l}\text { (Dotterweich } \\
2008,2013)\end{array}$ & Reviews & $\begin{array}{l}\text { European (2008) and global (2013) synthesis on catchment } \\
\text { erosion: Methods and major findings }\end{array}$ & \\
\hline Croudace et & Journal & Descriptions, evaluations, and introduction of XRF-core scanning & n \\
\hline
\end{tabular}




\begin{tabular}{|c|c|c|c|}
\hline al. (2006) & Article & technologies & \\
\hline $\begin{array}{l}\text { Davies et al. } \\
(2015)\end{array}$ & Book Chapter & $\begin{array}{l}\text { In-depth review of literature using XRF-core scanning elements } \\
\text { and elemental ratio on lacustrine sediments for reconstruction of } \\
\text { catchment erosion }\end{array}$ & \\
\hline $\begin{array}{l}\text { Arnaud et al. } \\
(2016)\end{array}$ & Review & $\begin{array}{l}\text { Review focusing on methodological approaches to reconstruct } \\
\text { erosion using XRF core scanning technologies with a particular } \\
\text { focus on flood dynamics. Regional focus on the European Alps. }\end{array}$ & \\
\hline $\begin{array}{l}\text { (Croudace et } \\
\text { al. 2019a, b) }\end{array}$ & $\begin{array}{l}\text { Journal } \\
\text { Articles }\end{array}$ & $\begin{array}{l}\text { State of the art and future perspectives of X-ray core scanner } \\
\text { technologies. Both manuscripts are part of a special issue } \\
\text { "Advances in Data Quantification and Application of high } \\
\text { resolution XRF Core Scanners" }\end{array}$ & \\
\hline $\begin{array}{l}\text { Leng and } \\
\text { Barker (2006) }\end{array}$ & Book & $\begin{array}{l}\text { Comprehensive introduction to the apt Ticat on of stable (carbon) } \\
\text { isotopes in palaeoenvironmental } r \text { sear } h \text { for lacustrine, marine, } \\
\text { and speleothem archives. }\end{array}$ & 蔍 \\
\hline $\begin{array}{l}\text { Leng and } \\
\text { Marshall } \\
(2004)\end{array}$ & Review & $\begin{array}{l}\text { Comprehensive review on } \mathrm{e} \text { a plication of stable, non-metal } \\
\text { is otope analyses as palaeocli nate } n d \text {-environmental proxy. }\end{array}$ & 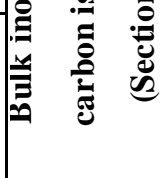 \\
\hline $\begin{array}{l}\text { DePaolo et al. } \\
\text { (2006) }\end{array}$ & Journal article & $\begin{array}{l}\text { Introduction of } r \text { tope analyses as measure for sediment } \\
\text { transport time } n d \text { catchment erosion }\end{array}$ & 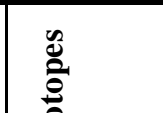 \\
\hline $\begin{array}{l}\text { Dosseto and } \\
\text { Schaller } \\
(2016)\end{array}$ & Review article & $\begin{array}{l}\text { Comprehe sive revıew of limitations and potential of uranium and } \\
\text { cosmoger ¿ nuc:ide analyses as measure for catchment erosion }\end{array}$ & 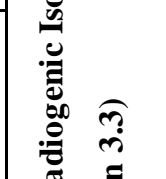 \\
\hline $\begin{array}{l}\text { Banner (2004) } \\
\text { and Blu m and } \\
\text { Erel (2003) }\end{array}$ & $\begin{array}{l}\text { Review } \\
\text { articles }\end{array}$ & $\begin{array}{l}\text { Thes, two articles provide generalities on radiogenic isotope } \\
\text { svsı ns and on their general behaviour during continental } \\
\text { wea nering. Various examples are given on their application in } \\
\text { he sedimentary record (Banner, 2004) and in hydrological studies } \\
\text { (Blum and Erel, 2003). }\end{array}$ & 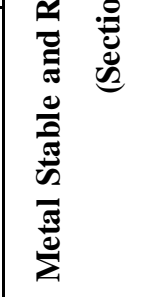 \\
\hline Dunai (2010) & Book & $\begin{array}{l}\text { Provides a comprehensive and accessible introduction to } \\
\text { cosmogenic nuclide analysis. More recent reviews also include } \\
\text { Granger et al (2013) and Granger and Riebe (2014). Also relevant, } \\
\text { although now outdated, is the EPSL Frontiers paper by von } \\
\text { Blanckenburg (2005). }\end{array}$ & 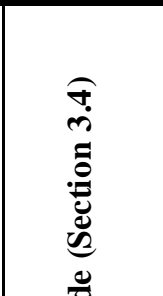 \\
\hline $\begin{array}{l}\text { (Bierman et } \\
\text { al. 2002; } \\
\text { Niedermann } \\
\text { 2002) }\end{array}$ & Book chapters & $\begin{array}{l}\text { Despite their age, both texts are useful to those looking for an } \\
\text { introduction to the technique in that they present details on sample } \\
\text { preparation and Be and } \mathrm{Al} \text { chemistry (Bierman et al, 2002), and } \\
\mathrm{Ne} \text { and } \mathrm{He} \text { isotope systematics (Niedermann et al 2002). }\end{array}$ & 导 \\
\hline $\begin{array}{l}\text { Granger } \\
(2006)\end{array}$ & Book chapter & $\begin{array}{l}\text { Comprehensive review of }{ }^{20} \mathrm{Al}^{\mathrm{I}}{ }^{10} \mathrm{Be} \text { burial dating with examples } \\
\text { of applications to geology and geomorphology. }\end{array}$ & 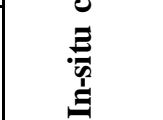 \\
\hline Balco & Journal article & The first paper to describe an ${ }^{20} \mathrm{Al}-{ }^{10} \mathrm{Be}$ isochron method for & \\
\hline
\end{tabular}




\begin{tabular}{|c|c|c|c|}
\hline Rovey (2008) & & cosmogenic-nuclide dating of buried soils and sediments. & \\
\hline $\begin{array}{l}\text { Hidy et al. } \\
(2010)\end{array}$ & Journal article & $\begin{array}{l}\text { Describes a Monte Carlo approach to modelling exposure ages } \\
\text { from depth-profiles of cosmogenic nuclides. Also produced a set } \\
\text { of MATLAB scripts for this purpose that have been widely used } \\
\text { by the research community. }\end{array}$ & \\
\hline $\begin{array}{l}\text { Peters et al. } \\
(2005)\end{array}$ & Book & $\begin{array}{l}\text { Detailed introduction of the biomarker concept, explaining the } \\
\text { origins of biomarkers, analytical techniques and applications in } \\
\text { environmental and archaeological research. }\end{array}$ & \multirow{4}{*}{ 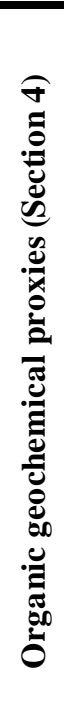 } \\
\hline $\begin{array}{l}\text { Freeman and } \\
\text { Pancost } \\
(2014)\end{array}$ & Book/Review & $\begin{array}{l}\text { Compact review of bio marker applications for the reconstruction } \\
\text { of terrestrial environmental change. }\end{array}$ & \\
\hline $\begin{array}{l}\text { Holtvoeth et } \\
\text { al. (2019) }\end{array}$ & Review & $\begin{array}{l}\text { Comprehensive review of principles a.d applications of } \\
\text { compound-specific isotope analyses (C,IA) for lacustrine } \\
\text { sediments. }\end{array}$ & \\
\hline $\begin{array}{l}\text { Fuhrmann et } \\
\text { al. (2003) }\end{array}$ & Journal article & $\begin{array}{c}\text { Example of a multi-method pala } \text { environmental study applying } \\
\text { bulk proxies, biomarker an lyse , compound-specific isotope } \\
\text { analyses ar } d \text { or } \text { nic petrology. }\end{array}$ & \\
\hline
\end{tabular}

Table 2: Applicability of the methods rf $\sqrt{ } \mathrm{lt} N \mathrm{e}^{\mathrm{J}}$

\begin{tabular}{|c|c|c|c|c|c|c|}
\hline Method & $\begin{array}{l}\text { Sediment } \\
\text { composition / } \\
\text { mineralogy }\end{array}$ & Grain size & $\begin{array}{l}\text { nplicable } \\
\text { time s pan } \\
\text { (ka) }\end{array}$ & $\begin{array}{l}\text { Catchment } \\
\text { geology }\end{array}$ & $\begin{array}{l}\text { Infor mation } \\
\text { derived }\end{array}$ & $\begin{array}{l}\text { Quantitative } \\
\text { / } \\
\text { Qualitative* }\end{array}$ \\
\hline $\begin{array}{l}\text { Sediment } \\
\text { chronology }\end{array}$ & $\begin{array}{l}\text { Depending on } \\
\text { dating method }\end{array}$ & $\begin{array}{l}\text { Depe.ı. } \\
\text { on dating } \\
\text { me hod }\end{array}$ & $\begin{array}{l}\text { Depending } \\
\text { on dating } \\
\text { method }\end{array}$ & $\begin{array}{l}\text { Depending } \\
\text { on dating } \\
\text { method }\end{array}$ & $\begin{array}{l}\text { Sediment } \\
\text { accumulation } \\
\text { / erosion } \\
\end{array}$ & $\begin{array}{l}\text { Quantitative } \\
\text { / Qualitative }\end{array}$ \\
\hline $\begin{array}{l}\text { Element } \\
\text { geochemis try }\end{array}$ & $\begin{array}{l}\text { Usually } \\
\text { siliciclastic } \\
\text { sediments }\end{array}$ & $\begin{array}{l}\text { Ne } \\
\text { limi ations }\end{array}$ & $\begin{array}{l}\text { No } \\
\text { limitations }\end{array}$ & $\begin{array}{l}\text { No } \\
\text { limitations }\end{array}$ & $\begin{array}{l}\text { Erosion and } \\
\text { weathering }\end{array}$ & Qualitative \\
\hline $\begin{array}{l}\text { Bulk } \\
\text { inorganic } \\
\text { carbon } \\
\text { isotopes }\end{array}$ & $\begin{array}{l}\text { Authigen. } \\
\text { endogenic } \\
\text { carbonates }\end{array}$ &.$\overline{1 / a}$ & $\begin{array}{l}\text { No } \\
\text { limitations / } \\
\text { depending on } \\
\text { preservation }\end{array}$ & $\begin{array}{l}\text { No } \\
\text { limitations, } \\
\text { limestone- } \\
\text { rich } \\
\text { catchment } \\
\text { for } \\
\text { application } \\
\text { on } \\
\text { carbonates }\end{array}$ & $\begin{array}{l}\text { Soil } \\
\text { evolution, } \\
\text { limestone } \\
\text { weathering }\end{array}$ & Qualitative \\
\hline $\mathrm{U}$ is otopes & $\begin{array}{l}\text { siliciclastic } \\
\text { sediments }\end{array}$ & $\begin{array}{l}<63 \mu \mathrm{m} \text { (silt } \\
\text { and clay) }\end{array}$ & $\begin{array}{l}>1 \mathrm{ka} \\
<400 \mathrm{ka}\end{array}$ & $\begin{array}{l}\text { Usually } \\
\text { bedrock } \\
\text { older } 1 \mathrm{Ma}\end{array}$ & $\begin{array}{l}\text { Erosion, } \\
\text { sediment } \\
\text { residence } \\
\text { time (in } \\
\text { kyrs) }\end{array}$ & Quantitative \\
\hline $\begin{array}{l}\mathrm{Hf}, \mathrm{Nd}, \mathrm{Pb} \\
\text { is otopes }\end{array}$ & $\begin{array}{l}\text { siliciclastic } \\
\text { sediments, } \\
\text { authigenic Fe- } \\
\text { oxide minerals }\end{array}$ & $\begin{array}{l}\text { Clay-size } \\
\text { sediments }\end{array}$ & $\begin{array}{l}\text { No } \\
\text { limitations }\end{array}$ & $\begin{array}{l}\text { No } \\
\text { limitations }\end{array}$ & $\begin{array}{l}\text { Weathering, } \\
\text { sediment } \\
\text { provenance }\end{array}$ & $\begin{array}{l}\text { Qualitative } \\
\text { (weathering), } \\
\text { quantitative } \\
\text { (provenance) }\end{array}$ \\
\hline $\begin{array}{l}\text { Cosmogenic } \\
\text { nuclides }\end{array}$ & Quartz & $\begin{array}{l}>150 \mu \mathrm{m} . \\
\text { Most } \\
\text { common for }\end{array}$ & $\begin{array}{ll}\begin{array}{l}\text { Limited } \\
\text { half-life }\end{array} & \text { of } \\
\text { chosen } & \end{array}$ & $\begin{array}{l}\text { Quartz } \\
\text { bearing } \\
\text { lithologies }\end{array}$ & $\begin{array}{l}\text { Erosion rate } \\
\text { (in } \mathrm{mm} / \mathrm{kyr} \text { ); } \\
\text { sediment }\end{array}$ & $\begin{array}{l}\text { Cosmogenic } \\
\text { nuclides }\end{array}$ \\
\hline
\end{tabular}




\begin{tabular}{|c|c|c|c|c|c|c|}
\hline & & $\begin{array}{l}\text { basin wide } \\
\text { denudation } \\
\text { studies: } 250 \\
-500 \mu \mathrm{m} . \\
\text { depth- } \\
\text { profile } \\
\text { dating and } \\
\text { burial dating } \\
\text { studies: } \\
\text { pebbles to } \\
\text { cobbles }\end{array}$ & $\begin{array}{l}\text { nuclide or } \\
\text { nuclide pair; } \\
\text { Burial ages } \\
\text { from a few } \\
\text { ka }\left({ }^{14} \mathrm{C}^{10} \mathrm{Be}\right. \\
\text { pair }) \text { to } 10 \\
\mathrm{Ma}\left({ }^{10} \mathrm{Be}-\right. \\
{ }^{21} \mathrm{Ne} \text { pair) }\end{array}$ & & $\begin{array}{l}\text { deposition } \\
\text { age (kyr to } \\
\text { Myr) }\end{array}$ & \\
\hline $\begin{array}{l}\text { Organic } \\
\text { geochemistry }\end{array}$ & Organic matter & $\begin{array}{l}\text { No } \\
\text { limitations }\end{array}$ & $\begin{array}{l}\text { No } \\
\text { limitations }\end{array}$ & $\begin{array}{l}\text { No } \\
\text { limitations }\end{array}$ & $\begin{array}{l}\text { Terrestrial } \\
\text { habitat } \\
\text { change, soil } \\
\text { organic } \\
\text { matter } \\
\text { supply }\end{array}$ & Qualitative \\
\hline
\end{tabular}

*Highlights if quantitative or qualitative data about lanr's ’ pe evolution (e.g. erosion rates in $\mathrm{mm} / \mathrm{yr}$ ) are provided.

\section{References}

Anderson NJ, Bennion H, Lotter AF (2 J14 La'ke eutrophication and its implications for organic carbon sequestration in - irope. Global Change Biology 20 (9):2741-2751. doi:10.1111/gcb.12584

Anderson RS, Repka JL, Dick GS '15?5) Explicit treatment of inheritance in dating depositional surfaces using ir, situ Be-10 and Al-26. Geology 24 (1):47-51. doi:Doi 10.1130/0091-7613(1996 02i-0047:Etoiid>2.3.Co;2

Argento DC, Stone JO, Reedy IC, ح'Brien K (2015a) Physics-based modeling of cosmogenic nuclides part I - Rarliacion transport methods and new insights. Quaternary Geochronology 26:2= 4?. doi:10.1016/j.quageo.2014.09.004

Argento DC, Stone JO, F eea 'RC, O'Brien K (2015b) Physics-based modeling of cosmogenic nuclides part II key aspects of in-situ cosmogenic nuclide production. Quaternary Geochronology Jf.44-55. doi:10.1016/j.quageo.2014.09.005

Arnaud F, Poulenard J, Giguet-Covex C, Wilhelm B, Révillon S, Jenny J-P, Revel M, Enters D, Bajard M, Fouinat L, Doyen E, Simonneau A, Pignol C, Chapron E, Vannière B, Sabatier $P$ (2016) Erosion under climate and human pressures: An alpine lake sediment perspective. Quaternary Science 152:1-18. doi:10.1016/j.quascirev.2016.09.018

Arnaud F, Révillon S, Debret M, Revel M, Chapron E, Jacob J, Giguet-Covex C, Poulenard J, Magny M (2012) Lake Bourget regional erosion patterns reconstruction reveals Holocene NW European Alps soil evolution and paleohydrology. Quaterna ry Science Reviews 51:81-92. doi:10.1016/j.quascirev.2012.07.025

Aubert D, Stille $P$, Probst A (2001) REE fractionation during granite weathering and removal by waters and suspended loads: $\mathrm{Sr}$ and $\mathrm{Nd}$ isotopic evidence. Geochimica Et Cosmochimica Acta 65 (3):387-406. doi:Doi 10.1016/S0016-7037(00)00546-9 
Baartman JEM, Masselink R, Keesstra SD, Temme AJAM (2013) Linking landscape morphological complexity and sediment connectivity. Earth Surface Processes and Landforms 38 (12):1457-1471. doi:10.1002/esp.3434

Balco G, Rovey CW (2008) An Isochron Method for Cosmogenic-Nuclide Dating of Buried Soils and Sediments. Am J Sci 308 (10):1083-1114. doi:10.2475/10.2008.02

Balco G, Shuster DL (2009) Production rate of cosmogenic Ne-21 in quartz estimated from Be-10, Al-26, and Ne-21 concentrations in slowly eroding Antarctic bedrock surfaces. Earth and Planetary Science Letters 281 (1-2):48-58. doi:10.1016/j.epsl.2009.02.006

Balco G, Stone JO, Lifton NA, Dunai TJ (2008) A complete and easily accessible means of calculating surface exposure ages or erosion rates from $\mathrm{Be}-10$ and $\mathrm{Al}-26$ measurements. Quaternary Geochronology 3 (3):174-195. doi:10.1016/j.quageo.2007.12.001

Banner JL (2004) Radiogenic isotopes: systematics and i oplications to earth surface processes and chemical stratigraphy. Earth-Science isviews 65 (3-4):141-194. doi:10.1016/S0012-8252(03)00086-2

Bar-Matthews M, Ayalon A (2004) Speleothems as pala zu'imate indicators, a case study from Soreq Cave located in the Eastern Mediterr «n ar Region, Israel. In: Batterbee R, Gasse F, Stickley C (eds) Past climate variabilitı tı, ough Europe and Africa. Springer, Dordrecht, pp 363-392

Bayon G, Burton KW, Soulet G, Vigier N, Dennielou 3, t, uubleau J, Ponzevera E, German CR, Nesbitt RW (2009) Hf and Nd isotopes ir rearine sediments: Constraints on global silicate weathering. Earth and PI=neıuy Science Letters 277 (3-4):318-326. doi:10.1016/j.epsl.2008.10.028

Bayon G, Dennielou B, Etoubleau J, Ponz 'era E, Toucanne S, Bermell S (2012) Intensifying weathering and land use in $i$ n age central Africa. Science 335 (6073):1219-1222. doi:10.1126/science.1215400

Bayon G, Schefuss E, Dupont L, Borg e' A V, Dennielou B, Lambert T, Mollenhauer G, Monin L, Ponzevera $E$, Skonieczny $;$, $n$ ?dre $L$ (2019) The roles of climate and human land-use in the late Holocene $r=$ intc: $:$ st crisis of Central Africa. Earth and Planetary Science Letters 505:30-41. doı.10..016/j.epsl.2018.10.016

Bayon G, Skonieczny C, DE:'vig ie C, Toucanne S, Bermell S, Ponzevera E, Andre L (2016) Environmental $\mathrm{H}-\mathrm{Na}$ isotopic decoupling in World river clays. Earth and Planetary Science Letters : 2 ช. $\angle 5$-36. doi:10.1016/j.epsl.2016.01.010

Bechtel A, Sachsenhrff: RF, Markic M, Gratzer R, Lücke A, Püttmann W (2003) Paleoenvironmental implications from biomarker and stable isotope investigations on the Pliocene Velenje lignite seam (Slovenia). Organic Geochemistry 34 (9):12771298. doi:10.1016/s0146-6380(03)00114-1

Berner RA (1994) GEOCARB II: A revised model of atmospheric CO[sub 2] over phanerozoic time. doi:10.2475/ajs.294.1.56

Bierman PR (2004) Rock to sediment - Slope to sea with Be-10 - Rates of landscape change. Annu Rev Earth PI Sc 32:215-255. doi:10.1146/annurev.earth.32.101802.120539

Bierman PR, Caffee MW, Davis PT, Marsella K, Pavich M, Colgan P, Mickelson D, Larsen J (2002) Rates and timing of earth surface processes from in situ-produced cosmogenic Be-10. Beryllium: Mineralogy, Petrology, and Geochemistry 50:147-205. doi:DOI 10.2138/rmg.2002.50.4

Bierman PR, Steig EJ (1996) Estimating rates of denudation using cosmogenic isotope abundances in sediment. Earth Surface Processes and Landforms 21 (2):125-139. doi:Doi 10.1002/(Sici)1096-9837(199602)21:2<125::Aid-Esp511>3.0.Co;2-8 
Blaauw M, Christen JA, Bennett KD, Reimer PJ (2018) Double the dates and go for Bayes Impacts of model choice, dating density and quality on chronologies. Quaternary Science Reviews 188:58-66. doi:10.1016/j.quascirev.2018.03.032

Bliedtner M, Schafer IK, Zech R, von Suchodoletz H (2018) Leaf wax n-alkanes in modern plants and topsoils from eastern Georgia (Caucasus) - implications for reconstructing regional paleovegetation. Biogeosciences 15 (12):3927-3936. doi:10.5194/bg-153927-2018

Blum JD, Erel Y (1995) A Silicate Weathering Mechanism Linking Increases in Marine Sr87/Sr-86 with Global Glaciation. Nature 373 (6513):415-418. doi:DOI $10.1038 / 373415 \mathrm{a0}$

Blum JD, Erel Y (2003) Radiogenic Isotopes in Weathering and Hydrology. In: Holland HD, Turekian KK (eds) Treatise on Geochemistry. Pergamon, Oxford, pp 365-392. doi:10.1016/B0-08-043751-6/05082-9

Borchers B, Marrero S, Balco G, Caffee M, Goehring B, Lifton V. Nishiizumi K, Phillips F, Schaefer J, Stone J (2016) Geological calibration of s/ alla ion production rates in the CRONUS-Earth project. Quaternary isochronology 31:188-198. doi:10.1016/j.quageo.2015.01.009

Boyle EA, Edmond JM, Sholkovitz ER (1977) Mechan1-m of Iron Removal in Estuaries. Geochimica Et Cosmochimica Acta 41 9):1313-1324. doi:Doi 10.1016/00167037(77)90075-8

Boyle JF, Chiverrell RC, Schillereff D (2015) Al pr siches to Water Content Correction and Calibration for $\mu$ XRF Core Scannir: Lumparing X-ray Scattering with Simple Regression of Elemental Concent atı uns. In: Croudace IW, Rothwell RG (eds) MicroXRF Studies of Sediment Cores. Ipplications of a non-destructive tool for the environmental sciences. Soringer Netherlands, Dordrecht, pp 373-390. doi:10.1007/978-94-017-9840 5 _.1

Brown ET (2011) Lake Malawi's I2rprinse to "megadrought" terminations: Sedimentary records of flooding, weache: ing and erosion. Palaeogeography, Palaeoclimatology, Palaeoecology 303 (1-4:1<i 125. doi:10.1016/j.palaeo.2010.01.038

Brown ET, Stallard RF, Larsen : 1c, Raisbeck GM, Yiou F (1995) Denudation Rates Determined from the Accumulatı $n$ rt in Situ-Produced Be-10 in the Luquillo Experimental Forest, Puerto-Rico. Ea th and Planetary Science Letters 129 (1-4):193-202. doi:Doi 10.1016/0012-১: $1 \times x ; j 4) 00249-X$

Bull ID, Lockheart MJ, Flh nmali MM, Roberts DJ, Evershed RP (2002) The origin of faeces by means of biomarker detection. Environment International 27 (8):647-654. doi:10.1016/S0160-4120(01)00124-6

Bush RT, Mclnerney FA (2013) Leaf wax n-alkane distributions in and across modern plants: Implications for paleoecology and chemotaxonomy. Geochimica et Cosmochimica Acta 117:161-179. doi:10.1016/j.gca.2013.04.016

Cao Y, Xing L, Zhang T, Liao WH (2017) Multi-proxy evidence for decreased terrestrial contribution to sedimentary organic matter in coastal areas of the East China Sea during the past 100years. Sci Total Environ 599-600:1895-1902. doi:10.1016/j.scitotenv.2017.05.159

Carretier S, Regard V, Leanni L, Farias M (2019) Long-term dispersion of river gravel in a canyon in the Atacama Desert, Central Andes, deduced from their Be-10 concentrations. Scientific Reports 9. doi:10.1038/s41598-019-53806-x 
Cazes G, Fink D, Codilean AT, Fülöp R-H, Fujioka T, Wilcken KM (2020) 26Al/10Be ratios reveal the source of river sediments in the Kimberley, NW Australia. Earth Surface Processes and Landforms 45 (2):424-439. doi:10.1002/esp.4744

Chatterjee A, Ray JS (2017) Sources and depositional pathways of mid-Holocene sediments in the Great Rann of Kachchh, India: Implications for fluvial scenario during the Harappan Culture. Quaternary International 443:177-187. doi:10.1016/j.quaint.2017.06.008

Chávez-Lara CM, Holtvoeth J, Roy PD, Pancost RD (2018) A 27cal ka biomarker-based record of ecosystem changes from lacustrine sediments of the Chihuahua Desert of Mexico. Quaternary Science Reviews 191:132-143. doi:10.1016/j.quascirev.2018.05.013

Chmeleff J, von Blanckenburg F, Kossert K, Jakob D (2010) Determination of the Be-10 halflife by multicollector ICP-MS and liquid scintillation counting. Nucl Instrum Meth B 268 (2):192-199. doi:10.1016/j.nimb.2009.09.012

Codilean AT (2006) Calculation of the cosmogenic nuclide produ tion topographic shielding scaling factor for large areas using DEMs. Earth Surfi ce t rocesses and Landforms 31 (6):785-794. doi:10.1002/esp.1336

Codilean AT, Bishop P, Stuart FM, Hoey TB, Fabel D 1 of nan SPHT (2008) Single-grain cosmogenic $21 \mathrm{Ne}$ concentrations in fluvial sedime. ts reveal spatially variable erosion rates. Geology 36 (2):159. doi:10.1130/g243C ’a.1

Codilean AT, Munack H, Cohen TJ, Saktura WM, Gra; A, : Yudd SM (2018) OCTOPUS: an open cosmogenic isotope and luminescence d-t? base. Earth Syst Sci Data 10 (4):21232139. doi:10.5194/essd-10-2123-2018

Cogez A, Meynadier L, Allègre C, Limmoi D, Heı.nan F, Gaillardet J (2015) Constraints on the role of tectonic and climate on erc. on revealed by two time series analys is of marine cores around New Zealand. Earth and Planetary Science Letters 410:174-185. doi:10.1016/j.epsl.2014.11.07?

Cordeiro LGSM, Carreira RS, Wage' e a ALR (2008) Geochemistry of fecal sterols in a contaminated estuary in sc theastern Brazil. Organic Geochemistry 39 (8):10971103. doi:10.1016/j.org eo hem.2008.02.022

Council NR (2001) Basic Resc ^rci. Opportunities in Earth Science. The National Academies Press, Washington, L' . r oi:doi:10.17226/9981

Croudace IW, Löwemar: L, Tjallingii R, Zolitschka B (2019a) Current perspectives on the capabilities of $r_{1}$. Th , esolution XRF core scanners. Quaternary International 514:5-15. doi:10.1016/j.ql'ai it.2019.04.002

Croudace IW, Löwemark L, Tjallingii R, Zolitschka B (2019b) High resolution XRF core scanners: A key tool for the environmental and palaeoclimate sciences. Quaternary International 514:1-4. doi:10.1016/j.quaint.2019.05.038

Croudace IW, Rindby A, Rothwell RG (2006) ITRAX: description and evaluation of a new multi-function X-ray core scanner. New Techniques in Sediment Core Analysis 267:51-63

Cuven S, Francus P, Lamoure ux SF (2010) Estimation of grain size variability with micro X-ray fluorescence in laminated lacustrine sediments, Cape Bounty, Canadian High Arctic. Journal of Paleolimnology 44 (3):803-817. doi:10.1007/s10933-010-9453-1

D'Anjou RM, Bradley RS, Balascio NL, Finkelstein DB (2012) Climate impacts on human settlement and agricultural activities in northern Norway revealed through sediment biogeochemistry. Proceedings of the National Academy of Sciences of the United States of America 109 (50):20332-20337. doi:10.1073/pnas.1212730109 
Dannhaus N, Wittmann H, Kram P, Christl M, von Blanckenburg F (2018) Catchment-wide weathering and erosion rates of mafic, ultramafic, and granitic rock from cosmogenic meteoric Be-10/Be-9 ratios. Geochimica Et Cosmochimica Acta 222:618-641. doi:10.1016/j.gca.2017.11.005

Davies SJ, Lamb HF, Roberts JS (2015) Micro-XRF Core Scanning in Paleolimnology: Recent Developments. In: Croudace I, Rothwell RG (eds) Micro-XRF studies of sediment cores, vol 17. Developments in Paleoenvironmental Research. Springer. doi:10.1007/978-94-017-9849-5_7

De Choudens-Sanchez V, Gonzalez LA (2009) Calcite and Aragonite Precipitation Under Controlled Instantaneous Supersaturation: Elucidating the Role of $\mathrm{CaCO} 3$ Saturation State and $\mathrm{Mg} / \mathrm{Ca}$ Ratio on Calcium Carbonate Polymorphism. Journal of Sedimentary Research 79 (6):363-376. doi:10.2110/jsr.2009.043

DePaolo DJ, Lee VE, Christensen JN, Maher K (2012) Uraniur comminution ages: Sediment transport and deposition time scales. Comptes Rendus Ginscience 344 (11-12):678687. doi:10.1016/j.crte.2012.10.014

DePaolo DJ, Maher K, Christensen JN, McManus J (2006) 'en' 'ment transport time measured with U-series isotopes: Results from ODP Nort' $1+1+1$ ntic drift site 984 . Earth and Planetary Science Letters 248 (1-2):394-410. dni·1乞 1016/j.epsl.2006.06.004

DiBiase RA (2018) Short communication: Incre sin, vertical attenuation length of cosmogenic nuclide production on steep slopios negates topographic shielding corrections for catchment erosion ater. Earth Surf Dynam 6 (4):923-931. doi:10.5194/esurf-6-923-2018

Diefendorf AF, Freeman KH, Wing SL ('-OL ?) Listribution and carbon isotope patterns of diterpenoids and triterpenoids in 1. , dern temperate $\mathrm{C}-3$ trees and their geochemical significance. Geochimicá Et Cosmochimica Acta 85:342-356. doi:10.1016/j.gca.2012.02.01?

Diefendorf AF, Patterson WP, Holn.den C, Mullins HT (2008) Carbon isotopes of marl and lake sediment organic $r$ attc reflect terrestrial landscape change during the late Glacial and early Hol cers $(16,800$ to 5,540 cal yr B.P.): a multiproxy study of lacustrine sediments a + Luigh Inchiquin, western Ireland. Journal of Paleolimnology 39 (1):101-115. doi:ı? 1r 07/s10933-007-9099-9

Dosseto A, Bourdon B, 7 urne $r$ SP (2008) Uranium-series isotopes in river materials: Insights into the timescu'es of erosion and sediment transport. Earth and Planetary Science Letters 265 (1-2l.1 -17 . doi:10.1016/j.epsl.2007.10.023

Dosseto A, Hesse PP, Maher K, Fryirs K, Turner S (2010) Climatic and vegetation control on sediment dynamics during the last glacial cycle. Geology 38 (5):395-398. doi:10.1130/g30708.1

Dosseto A, Schaller M (2016) The erosion response to Quaternary climate change quantified using uranium isotopes and in situ-produced cosmogenic nuclides. Earth-Science Reviews 155:60-81. doi:10.1016/j.earscirev.2016.01.015

Dotterweich M (2008) The history of soil erosion and fluvial deposits in small catchments of central Europe: Deciphering the long-term interaction between humans and the environment - A review. Geomorphology $101 \quad$ (1-2):192-208. doi:10.1016/j.geomorph.2008.05.023

Dotterweich M (2013) The history of human-induced soil erosion: Geomorphic legacies, early descriptions and research, and the development of soil conservation -A global synopsis. Geomorphology 201:1-34. doi:10.1016/j.geomorph.2013.07.021 
Drake TW, Van Oost K, Barthel M, Bauters M, Hoyt AM, Podgorski DC, Six J, Boeckx P, Trumbore SE, Cizungu Ntaboba L, Spencer RGM (2019) Mobilization of aged and biolabile soil carbon by tropical deforestation. Nature Geoscience 12 (7):541-546. doi:10.1038/s41561-019-0384-9

Dreibrodt S, Lubos C, Terhorst B, Damm B, Bork HR (2010) Historical soil erosion by water in Germany: Scales and archives, chronology, research perspectives. Quaternary International 222 (1-2):80-95. doi:10.1016/j.quaint.2009.06.014

Dunai TJ (2010) Cosmogenic Nuclides - Principles, Concepts and Applications in the Earth Surface Sciences. Cambridge University Press, Cambridge

Dunne J, Elmore D, Muzikar P (1999) Scaling factors for the rates of production of cosmogenic nuclides for geometric shielding and attenuation at depth on sloped surfaces. Geomorphology 27 (1-2):3-11. doi:Doi 10.1016/S0169-555x(98)00086-5

Eglinton G, Hamilton RJ (1967) Leaf Epicuticular Waxe. Science 156 (3780):1322. doi:10.1126/science.156.3780.1322

Erlanger ED, Granger DE, Gibbon RJ (2012) Rock uplift rate ; in South Africa from isochron burial dating of fluvial and marine terraces. Geology 40 (11):1019-1022. doi:10.1130/G33172.1

Fontanier C, Mamo B, Toucanne S, Bayon G, Schmidt $\varsigma$. حeflandre B, Dennielou B, Jouet G, Garnier E, Sakai S, Lamas RM, Duros P, Tc, fful u T, Sale A, Belleney D, Bichon S, Boissier A, Cheron S, Pitel M, Roubi A, Rover - MI, Gremare A, Dupre S, Jorry SJ (2018) Are deep-sea ecosystems surrounding $\Lambda$ ar'a sascar threatened by land-use or climate change? Deep-Sea Res Pt I 131:93-10ก dvi.10.1016/j.dsr.2017.11.011

Francke A, Carney S, Wilcox P, Dosseto A ( 20^己) Sample preparation for determination of comminution ages in lacustrine a. I marine sediments. Chemical Geology 479:123135. doi:10.1016/j.chemgeo.2?18.01.003

Francke A, Dosseto A, Panagiotop: ilo K, Leicher N, Lacey JH, Kyrikou S, Wagner B, Zanchetta G, Kouli K, Leng NJ $(2,19)$ Sediment residence time reveals Holocene shift from climatic to vegetation c.ntrol on catchment erosion in the Balkans. Global and Planetary Change 177:1 36-¿200. doi:10.1016/j.gloplacha.2019.04.005

Francke A, Wagner B, Just J, Li icr,ar N, Gromig R, Baumgarten H, Vogel H, Lacey JH, Sadori L, Wonik T, Leng MJ, 7.a ıchetta G, Sulpizio R, Giaccio B (2016) Sedimentological processes and er viro ' mental variability at Lake Ohrid (Macedonia, Albania) between $637 \mathrm{ka}$ and the $\mathrm{n} r$ sent. Biogeosciences 13 (4):1179-1196. doi:10.5194/bg-13-11792016

Freeman KH, Pancost RD (2014) Biomarkers for Terrestrial Plants and Climate. In: Holland HD, Turekian KK (eds) Treatise on Geochemistry (Second Edition). Elsevier, Oxford, pp 395-416. doi:10.1016/978-0-08-095975-7.01028-7

Fuhrmann A, Mingram J, Lucke A, Lu HY, Horsfield B, Liu JQ, Negendank JFW, Schleser GH, Wilkes $H$ (2003) Variations in organic matter composition in sediments from Lake Huguang Maar (Huguangyan), South China during the last 68 ka: implications for environmental and climatic change. Organic Geochemistry 34 (11):1497-1515. doi:10.1016/S0146-6380(03)00158-X

Fülöp RH, Codilean AT, Wilcken KM, Cohent TJ, Fink D, Smith AM, Yang B, Levchenko VA, Wacker L, Marx SK, Stromsoe N, Fujioka T, Dunai TJ (in press) Million-year lag times in a post-orogenic sediment conveyor. . Science Advances

Gaillardet J, Dupré B, Louvat P, Allègre CJ (1999) Global silicate weathering and CO2 consumption rates deduced from the chemistry of large rivers. Chemical Geology 159 (1):3-30. doi:10.1016/S0009-2541(99)00031-5 
Gierga M, Hajdas I, van Raden UJ, Gilli A, Wacker L, Sturm M, Bernasconi SM, Smittenberg $\mathrm{RH}$ (2016) Long-stored soil carbon released by prehistoric land use: Evidence from compound-specific radiocarbon analysis on Soppensee lake sediments. Quaternary Science Reviews 144:123-131. doi:10.1016/j.quascirev.2016.05.011

Giosan L, Ponton C, Usman M, Blusztajn J, Fuller DQ, Galy V, Haghipour N, Johnson JE, McIntyre C, Wacker L, Eglinton TI (2017) Short communication: Massive erosion in monsoonal central India linked to late Holocene land cover degradation. Earth Surf Dynam 5 (4):781-789. doi:10.5194/esurf-5-781-2017

Giri SJ, Diefendorf AF, Lowell TV (2015) Origin and sedimentary fate of plant-derived terpenoids in a small river catchment and implications for terpenoids as quantitative paleovegetation proxies. Organic Geochemistry 82:22-32. doi:10.1016/j.orggeochem.2015.02.002

Goldberg K, Humayun M (2010) The applicability of the Che nical Index of Alteration as a paleoclimatic indicator: An example from the Permian \& the Paraná Basin, Brazil. Palaeogeography, Palaeoclimatology, Palaeoe oloky 293 (1-2):175-183. doi:10.1016/j.palaeo.2010.05.015

Goldstein SJ, Jacobsen SB (1988) Nd and Sr Isotopic Sy ,tt $m=$ ics of River Water Suspended Material - Implications for Crustal Evolution. Far '.' and Planetary Science Letters 87 (3):249-265. doi:Doi 10.1016/0012-821x(88)= 101: -1

Gontier A, Rihs S, Chabaux F, Lemarchand D, Pelt E, I. rpault M-P (2015) Lack of bedrock grain size influence on the soil product $\mathrm{O}^{\mathrm{r}}$, rate. Geochimica et Cosmochimica Acta 166:146-164. doi:10.1016/j.gca.2015.r.j.uiv

Graca J, Santos S (2007) Suberin: A bior sly, ste, of plants' skin. Macromol Biosci 7 (2):128135. doi:10.1002/mabi.200600218

Granger DE (2006) A review of burill dating methods using 26Al and 10Be. In: Siame L, Bourlès D, Brown E (eds) In-s:- I-r. sduced Cosmogenic Nuclides and Quantification of Geological Processes, vol $\angle \perp 5$. Geological Society of America Special Paper. Geological Society of Amєrica, pp 1-16

Granger DE, Kirchner JW, Fi kke R (1996) Spatially averaged long-term erosion rates measured from in situ ,ruduced cosmogenic nuclides in alluvial sediment. J Geol 104 (3):249-257. doi:Doi : ?.1086/629823

Granger DE, Muzikar PF (2८)1) Dating sediment burial with in situ-produced cosmogenic nuclides: theory, teuiniques, and limitations. Earth and Planetary Science Letters 188 (1-2):269-281. dni Joi 10.1016/S0012-821x(01)00309-0

Granger DE, Schaller M (2014) Cosmogenic Nuclides and Erosion at the Watershed Scale. Elements 10 (5):369-373. doi:10.2113/gselements.10.5.369

Granger DE, Smith AL (2000) Dating buried sediments using radioactive decay and muogenic production of Al-26 and Be-10. Nucl Instrum Meth B 172:822-826

Gregory BRB, Patterson RT, Reinhardt EG, Galloway JM (2019) The iBox-FC: A new containment vessel for Itrax X-ray fluorescence core-scanning of freeze cores. Quaternary International 514:76-84. doi:10.1016/j.quaint.2018.09.008

Handley HK, Turner S, Afonso JC, Dosseto A, Cohen T (2013a) Sediment residence times constrained by uranium-series isotopes: A critical appraisal of the comminution approach. Geochimica et Cosmochimica Acta 103:245-262. doi:10.1016/j.gca.2012.10.047

Handley HK, Turner SP, Dosseto A, Haberlah D, Afonso JC (2013b) Considerations for U-series dating of sediments: Insights from the Flinders Ranges, South Australia. Chemical Geology 340:40-48. doi:10.1016/j.chemgeo.2012.12.003 
Hare VJ, Loftus E, Jeffrey A, Ramsey CB (2018) Atmospheric CO2 effect on stable carbon isotope composition of terrestrial fossil archives. Nature Communications 9 (1):252. doi:10.1038/s41467-017-02691-x

Harel MA, Mudd SM, Attal M (2016) Global analysis of the stream power law parameters based on worldwide Be-10 denudation rates. Geomorphology 268:184-196. doi:10.1016/j.geomorph.2016.05.035

Harlavan Y, Erel Y, Blum JD (1998) Systematic changes in lead isotopic composition with soil age in glacial granitic terrains. Geochimica Et Cosmochimica Acta 62 (1):33-46. doi:Doi 10.1016/S0016-7037(97)00328-1

Harnois L (1988) The CIW index: A new chemical index of weathering. Sedimentary Geology 55 (3):319-322. doi:10.1016/0037-0738(88)90137-6

Hasberg AKM, Bijaksana S, Held P, Just J, Melles M, Morlock MA, Opitz S, Russell JM, Vogel $\mathrm{H}$, Wennrich V, Kwiecien O (2019) Modern sedimenta inn processes in Lake Towuti, Indonesia, revealed by the composition of surface sec:"ments. Sedimentology 66 (2):675-698. doi:10.1111/sed.12503

Hedges JI, Mann DC (1979) Characterization of Plant- ${ }^{\prime}$ is 'les by Their Lignin OxidationProducts. Geochimica Et Cosmochimica lich 43 (11):1803-1807. doi:Doi 10.1016/0016-7037(79)90028-0

Hernández-Vázquez L, Palazon J, Navarro-Ocaña A ' '01;) The pentacyclic triterpenes $\alpha-, \beta$ amyrins: a review of sources and biological -ctivities. In: Rao V (ed) Phytochemicals A Global Perspective of Their Role in N $\mathrm{dtr}$.tion and Health, vol 23. IntechOpen Ltd., London, pp 487-502. doi:10.5772/138;

Hidy AJ, Gosse JC, Pederson JL, Matte' $n J$, I:nkel RC (2010) A geologically constrained Monte Carlo approach to mode: ig exposure ages from profiles of cosmogenic nuclides: An example from, lees rerry, Arizona. Geochem Geophy Geosy 11. doi:10.1029/2010gc003084

Holtvoeth J, Kolonic S, Wagner T ( $2 \mathrm{~J}^{\prime}, 5$ Soil organic matter as an important contributor to late Quaternary sediments of the tropical West African continental margin. Geochimica Et Cosmoct ımı? Acta 69 (8):2031-2041. doi:10.1016/j.gca.2004.09.030

Holtvoeth J, Rushworth D, C C $\urcorner \epsilon_{j}$ H, Imeri A, Cara M, Vogel H, Wagner T, Wolff GA (2016) Improved end-me $\mathrm{m}_{\mathrm{w}} \sim \mathrm{r}$ r haracterisation of modern organic matter pools in the Ohrid Basin (Albania, Mac donia) and evaluation of new palaeoenvironmental proxies. Biogeosciences : 3 (J):795-816. doi:10.5194/bg-13-795-2016

Holtvoeth J, Vogel H, V Ic acchi V, Lindhorst K, Schouten S, Wagner B, Wolff GA (2017) Linear and non-linear responses of vegetation and soils to glacial-interglacial climate change in a Mediterranean refuge. Sci Rep 7 (1):8121. doi:10.1038/s41598-017-08101-y

Holtvoeth J, Whiteside JH, Engels S, Freitas FS, Grice K, Greenwood P, Johnson S, Kendall I, Lengger SK, Lucke A, Mayr C, Naafs BDA, Rohrssen M, Sepulveda J (2019) The paleolimnologist's guide to compound-specific stable isotope analysis - An introduction to principles and applications of CSIA for Quaternary lake sediments. Quaternary Science Reviews 207:101-133. doi:10.1016/j.quascirev.2019.01.001

Hopmans EC, Weijers JWH, Schefuß E, Herfort L, Sinninghe Damsté JS, Schouten S (2004) A novel proxy for terrestrial organic matter in sediments based on branched and isoprenoid tetraether lipids. Earth and Planetary Science Letters 224 (1-2):107-116. doi:10.1016/j.epsl.2004.05.012

Huang Y, Street-Perrott FA, Metcalfe SE, Brenner M, Moreland M, Freeman KH (2001) Climate change as the dominant control on glacial-interglacial variations in C-3 and C4 plant abundance. Science 293 (5535):1647-1651. doi:DOI 10.1126/science.1060143 
Hughen KA, Eglinton TI, Xu L, Makou M (2004) Abrupt tropical vegetation response to rapid climate changes. Science 304 (5679):1955-1959. doi:10.1126/science.1092995

Hyodo F, Kuwae M, Sasaki N, Hayashi R, Makino W, Kusaka S, Tsugeki NK, Ishida S, Ohtsuki H, Omoto K, Urabe J (2017) Variations in lignin-derived phenols in sediments of Japanese lakes over the last century and their relation to watershed vegetation. Organic Geochemistry 103:125-135. doi:10.1016/j.orggeochem.2016.11.001

IPCC (2014) Climate Change 2014: Synthes is Report. Contribution of Working Groups I, II and III to the Fifth Assessment Report of the Intergovernmental Panel on Climate Change. IPCC,

Jacob J, Disnar JR, Arnaud F, Chapron E, Debret M, Lallier-Verges E, Desmet M, Revel-Rolland $M(2008)$ Millet cultivation history in the French Alps as evidenced by a sedimentary molecule. Journal of Archaeological Science 35 (3):814-820. doi:10.1016/j.jas.2007.06.006

Jacob J, Disnar JR, Boussafir M, Albuquerque ALS, Sifeddine A, Turcq B (2005) Pentacyclic triterpene methyl ethers in recent lacustrine sedi nenis (Lagoa do Caco, Brazil). Organic Geochemistry 36 (3):449-461. doi:10.1016' j.c 'ggeochem.2004.09.005

James LA (2013) Impacts of Early Agriculture and Defor si 'ti', n on Geomorphic Systems. In: Shroder JF (ed) Treatise on Geomorphology. ^ra Jemic Press, San Diego, pp 48-67. doi:10.1016/B978-0-12-374739-6.00342-0

Ji HS, Ding YJ, Liu XY, Li LQ, Zhang DX, Li ZC, Sun JL, I ashu ri MS, Joseph S, Meng YD, Kuzyakov Y, Pan GX (2015) Root-Derived Short-Ch tir. ? uberin Diacids from Rice and Rape Seed in a Paddy Soil under Rice Zuıvivar Treatments. Plos One 10 (5). doi:10.1371/journal. pone.012747/.

Jin L, Ogrinc N, Hamilton SK, Szramek $\therefore$ Kanduc T, Walter LM (2009) Inorganic carbon isotope systematics in soil $p$-rfiles undergoing silicate and carbonate weathering (Southern Michigan, I:SA). Chemical Geology 264 (1):139-153. doi:10.1016/j.chemgeo.2009.0 3.1/U2

Kaplan JO, Krumhardt KM, Zi nmirmann N (2009) The prehistoric and preindustrial deforestation of Eurspe. Quaternary Science Reviews 28 (27):3016-3034. doi:10.1016/j.quascirt : 2uj9.09.028

Keeling CD (1979) The S.es; effect: 13Carbon-14Carbon interrelations. Environment International 2 ( $<1: 2<$ )-300. doi:10.1016/0160-4120(79)90005-9

Kigoshi K (1971) Alpı.?-ıccoil Thorium-234: Dissolution into water and the uranium234/uranium-239 disequilibrium in nature. Science 173 (3991):47

Klein Goldewijk K, Beusen A, Doelman J, Stehfest E (2017) Anthropogenic land use estimates for the Holocene - HYDE 3.2. Earth Syst Sci Data 9 (2):927-953. doi:10.5194/essd-9927-2017

Konneke M, Schubert DM, Brown PC, Hugler M, Standfest S, Schwander T, von Borzyskowski LS, Erb TJ, Stahl DA, Berg IA (2014) Ammonia-oxidizing archaea use the most energyefficient aerobic pathway for $\mathrm{CO} 2$ fixation. Proceedings of the National Academy of Sciences of the United States of America 111 (22):8239-8244. doi:10.1073/pnas.1402028111

Korschinek G, Bergmaier A, Faestermann T, Gerstmann UC, Knie K, Rugel G, Wallner A, Dillmann I, Dollinger $G$, von Gostomski CL, Kossert K, Maiti M, Poutivtsev $M$, Remmert A (2010) A new value for the half-life of Be-10 by Heavy-lon Elastic Recoil Detection and liquid scintillation counting. Nucl Instrum Meth B 268 (2):187-191. doi:10.1016/j.nimb.2009.09.020 
Korup O, Densmore AL, Schlunegger F (2010) The role of landslides in mountain range evolution. Geomorphology 120 (1-2):77-90. doi:10.1016/j.geomorph.2009.09.017

Koven CD, Ringeval B, Friedlingstein $P$, Ciais $P$, Cadule $P$, Khvorostyanov D, Krinner $G$, Tarnocai C (2011) Permafrost carbon-climate feedbacks accelerate global warming. Proc Natl Acad Sci U S A 108 (36):14769-14774. doi:10.1073/pnas.1103910108

Kump LR, Brantley SL, Arthur MA (2000) Chemical Weathering, Atmospheric CO2, and Climate. Annu Rev Earth PI Sc 28 (1):611-667. doi:10.1146/annurev.earth.28.1.611

Kylander ME, Ampel L, Wohlfarth B, Veres D (2011) High-resolution X-ray fluorescence core scanning analysis of Les Echets (France) sedimentary sequence: new insights from chemical proxies. Journal of Quaternary Science 26 (1):109-117. doi:10.1002/jqs.1438

Lacey JH, Leng MJ, Francke A, Sloane HJ, Milodowski A, Vogel H, Baumgarten H, Zanchetta G, Wagner B (2016) Northern Mediterranean climate si ice the Middle Pleistocene: a 637 ka stable isotope record from Lake Ohrid (Albania/ı'7cedonia). Biogeosciences 13 (6):1801-1820. doi:10.5194/bg-13-1801-2016

Lacey JH, Leng MJ, Peckover EN, Dean JR, Wilke T, Fran .кc A, Zhang X, Masi A, Wagner B (2018) Investigating the environmental interpre'a inn of oxygen and carbon isotope data from whole and fragmented bivalve shellc L'aternary Science Reviews 194:5561. doi:10.1016/j.quascirev.2018.06.025

Lal D (1991) Cosmic-Ray Labeling of Erosion Surfac s - :nsitu Nuclide Production-Rates and Erosion Models. Earth and Planetary sr.ence Letters 104 (2-4):424-439. doi:Doi 10.1016/0012-821x(91)90220-C

Langenheim JH (1994) Higher-Plant Terp snc ds a Phytocentric Overview of Their Ecological Roles. J Chem Ecol 20 (6):1223-12c doi:Doi 10.1007/Bf02059809

Lapointe F, Francus P, Lamoureux S.' Saïd M, Cuven S (2012) 1750 years of large rainfall events inferred from particle :ize tt East Lake, Cape Bounty, Melville Island, Canada. Journal of Paleolimnology $4 \delta($ ( ): $159-173$. doi:10.1007/s10933-012-9611-8

Lee V, DePaolo DJ, Christensen IN (¿ר10a) Uranium-series comminution ages of continental sediments: Case stud!' ot : Pleistocene alluvial fan. Earth and Planetary Science Letters $296(3-4): 244-<54$

Lee VE, DePaolo DJ, Christeı.-er JN (2010b) Uranium-series comminution ages of continental sediments: Case stu'y of a Pleistocene alluvial fan. Earth and Planetary Science Letters $296(3-4 ; \cdot ?$-44-254. doi:10.1016/j.epsl.2010.05.005

Leeming R, Ball A, Ashhn'i N, Jones G, Nichols $P(1994)$ Distinguishing between human and animal sources of faecal pollution. Chemistry in Australia 61:434-435

Leng MJ, Barker PA (2006) A review of the oxygen isotope composition of lacustrine diatom silica for palaeoclimate reconstruction. Earth-Science Reviews 75 (1-4):5-27. doi:10.1016/j.earscirev.2005.10.001

Leng MJ, Marshall JD (2004) Palaeoclimate interpretation of stable isotope data from lake sediment archives. Quaternary Science Reviews 23 (7,Äì):811-831. doi:10.1016/j.quascirev.2003.06.012

Lenton TM, Rockström J, Gaffney O, Rahmstorf S, Richardson K, Steffen W, Schellnhuber HJ (2019) Climate tipping points - too risky to bet against. Nature 575:592-595. doi:10.1038/d41586-019-03595-0

Lewis SL, Lopez-Gonzalez G, Sonké B, Affum-Baffoe K, Baker TR, Ojo LO, Phillips OL, Reitsma JM, White L, Comiskey JA, K M-ND, Ewango CEN, Feldpausch TR, Hamilton AC, Gloor M, Hart T, Hladik A, Lloyd J, Lovett JC, Makana J-R, Malhi Y, Mbago FM, Ndangalasi HJ, Peacock J, Peh KSH, Sheil D, Sunderland T, Swaine MD, Taplin J, Taylor D, Thomas 
SC, Votere R, Wöll H (2009) Increasing carbon storage in intact African tropical forests. Nature 457 (7232):1003-1006. doi:10.1038/nature07771

Li F, Gaillard M-J, Cao X, Herzschuh U, Sugita S, Tarasov PE, Wagner M, Xu Q, Ni J, Wang W, Zhao Y, An C, Beusen AHW, Chen F, Feng Z, Goldewijk CGMK, Huang X, Li Y, Li Y, Liu H, Sun A, Yao Y, Zheng Z, Jia X (2020) Towards quantification of Holocene anthropogenic land-cover change in temperate China: A review in the light of pollen-based REVEALS reconstructions of regional plant cover. Earth-Science Reviews 203:103119. doi:10.1016/j.earscirev.2020.103119

Li L, Chen J, Chen T, Chen Y, Hedding DW, Li G, Li L, Li T, Robinson LF, West AJ, Wu W, You CF, Zhao L, Li G (2018) Weathering dynamics reflected by the response of riverine uranium isotope disequilibrium to changes in denudation rate. Earth and Planetary Science Letters 500:136-144. doi:10.1016/j.epsl.2018.08.008

Li L, Li L, Li G (2017) Uranium comminution age responds to er șion rate semi-quantitatively. Acta Geochimica 39 (3):426-428. doi:10.1007/s11631-01\% n182-2

Lifton N, Sato T, Dunai TJ (2014) Scaling in situ cosmogenic nuc'ide production rates using analytical approximations to atmospheric cosmi $-1 \mathrm{~V}$ r rluxes. Earth and Planetary Science Letters 386:149-160. doi:10.1016/j.epsI..0. 2 1 J.0.052

Ma L, Chabaux F, Pelt E, Blaes E, Jin L, Brantley S (201n) n 'golith production rates calculated with uranium-series isotopes at Susquehan. $7 /$ St ale Hills Critical Zone Observatory. Earth and Planetary Science letters 297 (1-2):211-225. doi:10.1016/j.epsl.2010.06.022

Ma L, Hurtt GC, Chini LP, Sahajpal R, Pongrat. J, - i ulking S, Stehfest E, Klein Goldewijk K, O' Leary D, Doelman JC (2019) Glok $A$, ran_ition Rules for Translating Land-use Change (LUH2) To Land-cover Change tu. CMIP6 using GLM2. Geosci Model Dev Discuss 2019:1-30. doi:10.5194/gmd-2719-146

Maher K, DePaolo DJ, Christensen :N (2006) U-Sr isotopic speedometer: Fluid flow and chemical weathering rates $\mathrm{n}$ aquifers. Geochimica et Cosmochimica Acta 70 (17):4417-4435. doi:10.1r.16; gca.2006.06.1559

Maher K, DePaolo DJ, Lin JCF ( $: 004$, Rates of silicate dissolution in deep-sea sediment: in situ measurement using $\iota{ }^{3} 3 i / U-238$ of pore fluids. Geochim Cosmochim Acta 68:46294648

Makhubela TV, Kramers JD, : cherler D, Wittmann H, Dirks PHGM, Winkler SR (2019) Effects of long soil sur.' 7 ce residence times on apparent cosmogenic nuclide denudation rates and burial ages in the Cradle of Humankind, South Africa. Earth Surface Processes and Landforms n/a (n/a). doi:10.1002/esp.4723

Marshall MH, Lamb HF, Huws D, Davies SJ, Bates R, Bloemendal J, Boyle J, Leng MJ, Umer M, Bryant C (2011) Late Pleistocene and Holocene drought events at Lake Tana, the source of the Blue Nile. Global and Planetary Change 78 (3-4):147-161. doi:10.1016/j.gloplacha.2011.06.004

Marston RA (2010) Geomorphology and vegetation on hillslopes: Interactions, dependencies, and feedback loops. Geomorphology 116 (3-4):206-217. doi:10.1016/j.geomorph.2009.09.028

Martin AN, Dosseto A, Kinsley LPJ (2015) Evaluating the removal of non-detrital matter from soils and sediment using uranium isotopes. Chemical Geology 396:124-133. doi:10.1016/j.chemgeo.2014.12.016

Martin AN, Dosseto A, May J-H, Jansen JD, Kinsley LPJ, Chivas AR (2019) Sediment residence times in catchments draining to the Gulf of Carpentaria, northern Australia, inferred 
by uranium comminution dating. Geochimica et Cosmochimica Acta 244:264-291. doi:10.1016/j.gca.2018.09.031

Martin-Puertas C, Brauer A, Dulski P, Brademann B (2012) Testing climate-proxy stationarity throughout the Holocene: an example from the varved sediments of Lake Meerfelder Maar (Germany). Quaternary Science Reviews 58:56-65. doi:10.1016/j.quascirev.2012.10.023

Masi A, Francke A, Pepe C, Thienemann M, Wagner B, Sadori L (2018) Vegetation history and paleoclimate at Lake Dojran (FYROM/Greece) during the Late Glacial and Holocene. Climate of the Past 14 (3):351-367. doi:10.5194/cp-14-351-2018

Matas AJ, Sanz MJ, Heredia A (2003) Studies on the structure of the plant wax nonacosan10-ol, the main component of epicuticular wax conifers. Int J Biol Macromol 33 (13):31-35. doi:10.1016/S0141-8130(03)00061-8

Mayser JP, Flecker R, Marzocchi A, Kouwenhoven TJ, Lunt DJ, Pancost RD (2017) Precession driven changes in terrestrial organic matter input to $L^{\prime} \bullet$ Eastern Mediterranean leading up to the Messinian Salinity Crisis. Earth ana Planetary Science Letters 462:199-211. doi:10.1016/j.epsl.2017.01.029

McPhillips D, Bierman PR, Rood DH (2014) Millennial-scal $r$ iord of landslides in the Andes consistent with earthquake trigger. Na+1s Geoscience 7 (12):925-930. doi:10.1038/Ngeo2278

Mendez-Millan M, Dignac MF, Rumpel C, Derenne S, 20, ${ }^{1}$ ) Can cutin and suberin biomarkers be used to trace shoot and root-derive $d$ srganic matter? A molecular and isotopic approach. Biogeochemistry 106 (1):23-38. vioi:10.1007/s10533-010-9407-8

Menozzi D, Dosseto A, Kinsley LPJ (2016) As. essing the effect of sequential extraction on the uranium-series isotopic composı: in of a basaltic weathering profile. Chemical Geology 446:126-137. doi:10.:1916/j.cnemgeo.2016.05.031

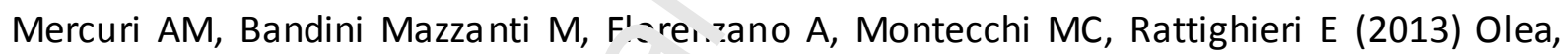
Juglans and Castanea: The C $\mathrm{JC}$ group as pollen evidence of the development of human-induced environreris in the Italian peninsula. Quaternary International 303:24-42. doi:10.1016/1.quint.2013.01.005

Molina I, Bonaventure G, Ori: 'os je J, Pollard M (2006) The lipid polyester composition of Arabidopsis thaliana эn'l Brassica napus seeds. Phytochemistry 67 (23):2597-2610. doi:10.1016/j.ph) tocr em.2006.09.011

Mook WG, Bommerso, 儿, Staverman WH (1974) Carbon isotope fractionation between dissolved bicarhn rate and gaseous carbon dioxide. Earth and Planetary Science Letters 22 (2):169-176. doi:10.1016/0012-821X(74)90078-8

Moore AK, Granger DE (2019) Calibration of the production rate of cosmogenic $\mathrm{Cl}-36$ from Fe. Quaternary Geochronology 51:87-98. doi:10.1016/j.quageo.2019.02.002

Morlock MA, Vogel H, Nigg V, Ordoñez L, Hasberg AKM, Melles M, Russell JM, Bijaksana S (2018) Climatic and tectonic controls on source-to-sink processes in the tropical, ultramafic catchment of Lake Towuti, Indonesia. Journal of Paleolimnology 61 (3):279-295. doi:10.1007/s10933-018-0059-3

Mudd SM (2017) Detection of transience in eroding landscapes. Earth Surface Processes and Landforms 42 (1):24-41. doi:10.1002/esp.3923

Muzikar P (2008) Cosmogenic nuclide concentrations in episodically eroding surfaces: Theoretical results. Geomorphology 97 (3-4):407-413. doi:10.1016/j.geomorph.2007.08.020 
Muzikar P (2009) General models for episodic surface denudation and its measurement by cosmogenic nuclides. Quaternary Geochronology 4 (1):50-55. doi:10.1016/j.quageo.2008.06.004

Muzikar P (2019) Episodic Erosion With a Power Law Probability Density, and the Accumulation of Cosmogenic Nuclides. J Geophys Res-Earth 124 (9):2345-2355. doi:10.1029/2019jf005095

Nesbitt HW, Young GM (1982) Early Proterozoic climates and plate motions inferred from major element chemistry of lutites. Nature 299 (5885):715-717. doi:10.1038/299715a0

Niedermann S (2002) Cosmic-ray-produced noble gases in terrestrial rocks: Dating tools for surface processes. Rev Mineral Geochem 47:731-784. doi:DOI 10.2138/rmg.2002.47.16

O'Leary MH (1981) Carbon isotope fractionation in plants. Pivtochemistry 20 (4):553-567. doi:10.1016/0031-9422(81)85134-5

Ostberg S, Boysen LR, Schaphoff S, Lucht W, Gerten D (201E' Th biosphere under potential paris outcomes. Earth's Future. doi:10.1002/2017es ง

Otto A, Simpson MJ (2005) Degradation and preser.əti un of vascular plant-derived biomarkers in grassland and forest soils from $\mathrm{N}_{\mathrm{L}}$-tern Canada. Biogeochemistry 74 (3):377-409. doi:10.1007/s10533-004-5834-E

Panagiotopoulos K, Aufgebauer A, Schäbitz F, W-gnt: B (2013) Vegetation and climate history of the Lake Prespa region sinc $\_+n$ ? Late Glacial. Quaternary International 292:157-169. doi:10.1016/j.quaint.201 '.0.j.u48

Panagiotopoulos K, Holtvoeth J, Kouli K, Ma inc a E, Francke A, Cvetkoska A, Jovanovska E, Lacey JH, Lyons ET, Buckel C, Beri I A, Donders T, Just J, Leicher N, Leng MJ, Melles M, Pancost RD, Sadori L, Tau'.'er P, vogel H, Wagner B, Wilke T (2020) Insights into the evolution of the young $I_{-1}^{-1}$ e ?hrid ecosystem and vegetation succession from a southern European refugiurr lluring the Early Pleistocene. Quaternary Science Reviews 227:106044. doi: 10.in16/j.quascirev.2019.106044

Panagos P, Katsoyiannis A (2019) s.il erosion modelling: The new challenges as the result of policy development. in Europe. Environmental Research 172:470-474. doi:10.1016/j.envres.?019.02.043

Peters KE, Walters CC, I Molc Jwan JM (2005) The Biomarker Guide - Second Edition, Part I Biomarkers an: sutopes in the Environment and Human History. Cambridge University Press

Portenga EW, Bierman PR (2011) Understanding Earth's eroding surface with 10Be. GSA Today

Post WM, Emanuel WR, Zinke PJ, Stangenberger AG (1982) Soil carbon pools and world life zones. Nature 298 (5870):156-159. doi:10.1038/298156a0

Price JR, Velbel MA (2003) Chemical weathering indices applied to weathering profiles developed on heterogeneous felsic metamorphic parent rocks.

Profe J, Ohlendorf C (2019) X-ray fluorescence scanning of discrete samples - An economical perspective. Quaternary International 514:68-75. doi:10.1016/j.quaint.2018.09.022

Prush VB, Oskin ME (2020) A mechanistic erosion model for cosmogenic nuclide inheritance in single-clast exposure ages. Earth and Planetary Science Letters 536. doi:10.1016/j.epsl.2020.116066

Regattieri E, Zanchetta G, Isola I, Zanella E, Drysdale RN, Hellstrom JC, Zerboni A, Dallai L, Tema E, Lanci L, Costa E, Magri F (2019) Holocene Critical Zone dynamics in an Alpine 
catchment inferred from a speleothem multiproxy record: disentangling climate and human influences. Sci Rep 9 (1):17829. doi:10.1038/s41598-019-53583-7

Renberg I, Brannvall ML, Bindler R, Emteryd O (2002) Stable lead isotopes and lake sediments - a useful combination for the study of atmospheric lead pollution history. Science of the Total Environment 292 (1-2):45-54. doi:10.1016/0048-9697(02)000323

Repka JL, Anderson RS, Finkel RC (1997) Cosmogenic dating of fluvial terraces, Fremont River, Utah. Earth and Planetary Science Letters 152 (1-4):59-73. doi:Doi 10.1016/S0012-821x(97)00149-0

Romanek CS, Grossman EL, Morse JW (1992) Carbon isotopic fractionation in synthetic aragonite and calcite: Effects of temperature and precipitation rate. Geochimica et Cosmochimica Acta 56 (1):419-430. doi:10.1016/0016-7037(92)90142-6

Rothacker L, Dosseto A, Francke A, Chivas AR, Vigier N, Kc carba-Morley AM, Menozzi D (2018) Impact of climate change and human activity on suil landscapes over the past 12,300 years. Scientific Reports 8 (1). doi:10.1038/s41598 017-18603-4

Russell JM, Mccoy SJ, Verschuren D, Bessems I, Huang ; ?uU9) Human impacts, climate change, and aquatic ecosystem response during ih. $n$-st 2000 yr at Lake Wandakara, Uganda. Quaternary Research 72 (3):315-324. No..10.1016/j.yqres.2009.06.008

Schaefer JM, Denton GH, Kaplan MR, Putnam A, Finl el RC, Barrell DJA, Andersen BG, Schwartz R, Mackintosh A, Chinn T, Schluc' iter ? (2009) High-Frequency Holocene Glacier Fluctuations in New Zealand Dif er f'om the Northern Signature. Science 324 (5927):622-625. doi:10.1126/science.1 L6sこ 12

Schillereff DN, Chiverrell RC, Macdonal'، N Hu ske JM (2014) Flood stratigraphies in lake sediments: A review. Earth-Science Reviews 135:17-37. doi:10.1016/j.earscirev.2014. $\iota^{2} .011$

Schouten S, Woltering M, Rijpstra $W_{i}$, Sluijs A, Brinkhuis H, Damste JSS (2007) The Paleocene-Eocene carbon is ot spe excursion in higher plant organic matter: Differential fractionation oi angiosperms and conifers in the Arctic. Earth and Planetary Science Letters 2.9 (3-4):581-592. doi:10.1016/j.epsl.2007.04.024

Schwark L, Zink K, Lechterbe-k : (2002) Reconstruction of postglacial to early Holocene vegetation history $\mathrm{I}_{1}$. terrestrial Central Europe via cuticular lipid biomarkers and pollen records fr Im । ike sediments. Geology 30 (5):463-466. doi:Doi 10.1130/00917613(2002)030< 7us:Ropteh>2.0.Co;2

Seki O, Mikami Y, Nagar S, Bendle JA, Nakatsuka T, Kim VI, Shesterkin VP, Makinov AN, Fukushima M, Moossen HM, Schouten S (2014) Lignin phenols and BIT index distributions in the Amur River and the Sea of Okhotsk: Implications for the source and transport of particulate terrestrial organic matter to the ocean. Prog Oceanogr 126:146-154. doi:10.1016/j.pocean.2014.05.003

Sharp Z (2007) Principles of Stable Isotope Geochemistry. Pearson Prentice Hall, New Jersey Sherwin MR, Vanvleet ES, Fossato VU, Dolci F (1993) Coprostanol (5-Beta-Cholestan-3-BetaOI) in Lagoonal Sediments and Mussels of Venice, Italy. Mar Pollut Bull 26 (9):501507. doi:Doi 10.1016/0025-326x(93)90467-X

Simoneit BRT (2002) Biomass burning - A review of organic tracers for smoke from incomplete combustion. Applied Geochemistry 17 (3):129-162. doi:10.1016/08832927(01)0001-0

Sinninghe Damsté J, Verschuren D, Ossebaar J, Blokker J, van Houten R, van der Meer MTJ, Plessen B, Schouten S (2011) A 25,000-year record of climate-induced changes in lowland vegetation of eastern equatorial Africa revealed by the stable carbon- 
isotopic composition of fossil plant leaf waxes. Earth and Planetary Science Letters 302 (1-2):236-246. doi:10.1016/j.epsl.2010.12.025

Skov DS, Egholm DL, Jansen JD, Sandiford M, Knudsen MF (2019) Detecting landscape transience with in situ cosmogenic C-14 and Be-10. Quaternary Geochronology 54. doi:10.1016/j.quageo.2019.101008

Small EE, Anderson RS, Repka JL, Finkel R (1997) Erosion rates of alpine bedrock summit surfaces deduced from in situ Be-10 and Al-26. Earth and Planetary Science Letters 150 (3-4):413-425. doi:Doi 10.1016/S0012-821x(97)00092-7

Smith RW, Bianchi TS, Li XX (2012) A re-evaluation of the use of branched GDGTs as terrestrial biomarkers: Implications for the BIT Index. Geochimica Et Cosmochimica Acta 80:14-29. doi:10.1016/j.gca.2011.11.025

Smittenberg RH, Eglinton TI, Schouten S, Damste JSS (2006) Ongoing buildup of refractory organic carbon in boreal soils during the Holocene. S :ience 314 (5803):1283-1286. doi:10.1126/science.1129376

Struck M, Jansen JD, Fujioka T, Codilean AT, Fink D, Eghc $(\mathrm{m}, \mathrm{I}$, Fulop RH, Wilcken KM, Kotevski S (2018a) Soil production and transport vi. postorogenic desert hillslopes quantified with Be-10 and Al-26. Geological ?a:ot, of America Bulletin 130 (56):1017-1040. doi:10.1130/B31767.1

Struck $M$, Jansen JD, Fujioka T, Codilean AT, Fin: $D$, =ulop RH, Wilcken KM, Price DM, Kotevski S, Fifield LK, Chappell J (2018b) Tra ikiric the Be-10-Al-26 source-area signal in sediment-routing systems of arid ce it' d' Australia. Earth Surf Dynam 6 (2):329349. doi:10.5194/esurf-6-329-2018

Süfke F, Gutjahr M, Gilli A, Anselmetti FS GI Ir L, Eisenhauer A (2019) Early stage weathering systematics of $\mathrm{Pb}$ and $\mathrm{Nd}$ isotc, es derived from a high-Alpine Holocene lake sediment record. Chemical Ge logy 5u7:42-53. doi:10.1016/j.chemgeo.2018.12.026

Sugita S (2007a) Theory of quantitati $\cdots r$ i instruction of vegetation I: pollen from large sites REVEALS regional vegetaii in composition. The Holocene 17 (2):229-241. doi:10.1177/0959683607(175¿27

Sugita S (2007b) Theory of qua ntitu+ive reconstruction of vegetation II: all you need is LOVE. The Holocene 17 (2): $2: 3$ 3-८57. doi:10.1177/0959683607075838

Suresh PO, Dosseto A, Haı. Nle/ HK, Hesse PP (2014a) Assessment of a sequential phase extraction proce lure for uranium-series isotope analys is of soils and sediments. Applied Radiatı $\urcorner$ aıd Isotopes 83 Pt A:47-55. doi:10.1016/j.apradiso.2013.10.013

Suresh PO, Dosseto A, H ssse PP, Handley HK (2013) Soil formation rates determined from uranium-series isotope disequilibria in soil profiles from the southeastern Australian highlands. Earth and Planetary Science Letters 379:26-37. doi:10.1016/j.epsl.2013.08.004

Suresh PO, Dosseto A, Hesse PP, Handley HK (2014b) Very long hillslope transport timescales determined from uranium-series isotopes in river sediments from a large, tectonically stable catchment. Geochimica et Cosmochimica Acta 142:442-457. doi:10.1016/j.gca.2014.07.033

Tankersley KB, Conover DG, Lentz DL, Callihan A, Weakley J, Hassett I, Platt E, Laiveling A, Bradford E (2019) The impact of maize (Zea mays) on the stable carbon isotope values of archaeological soil organic matter. J Archaeol Sci-Rep 24:324-329. doi:10.1016/j.jasrep.2019.01.024

Tierney JE, Russell JM, Huang YS (2010) A molecular perspective on Late Quaternary climate and vegetation change in the Lake Tanganyika basin, East Africa. Quaternary Science Reviews 29 (5-6):787-800. doi:10.1016/j.quas cirev.2009.11.030 
Trondman AK, Gaillard MJ, Mazier F, Sugita S, Fyfe R, Nielsen AB, Twiddle C, Barratt P, Birks $H J$, Bjune AE, Bjorkman L, Brostrom A, Caseldine C, David R, Dodson J, Dorfler W, Fischer E, van Geel B, Giesecke T, Hultberg T, Kalnina L, Kangur M, van der Knaap P, Koff T, Kunes $P$, Lageras $P$, Latalowa $M$, Lechterbeck J, Leroyer $C$, Leydet $M$, Lindbladh M, Marquer L, Mitchell FJ, Odgaard BV, Peglar SM, Persson T, Poska A, Rosch M, Seppa H, Veski S, Wick L (2015) Pollen-based quantitative reconstructions of Holocene regional vegetation cover (plant-functional types and land-cover types) in Europe suitable for climate modelling. Glob Chang Biol 21 (2):676-697. doi:10.1111/gcb.12737

Unkel I, Fernandez M, Björck S, Ljung K, Wohlfarth B (2010) Records of environmental changes during the Holocene from Isla de los Estados $\left(54.4^{\circ} \mathrm{S}\right)$, southeastern Tierra del Fuego. Global and Planetary Change 74 (3-4):99-113. doi:10.1016/j.gloplacha.2010.07.003

Valentin C, Poesen J, Li Y (2005) Gully erosion: Impacts, facto - and control. CATENA 63 (2):132-153. doi:10.1016/j.catena.2005.06.001

Van Daele M, Moernaut J, Silversmit G, Schmidt S, Fontii 4 $\therefore$, neirman K, Vandoorne W, De Clercq M, Van Acker J, Wolff C, Pino M, Urrutia R, Rr serts SJ, Vincze L, De Batist M (2014) The $600 \mathrm{yr}$ eruptive history of Villarric $V^{\prime \prime}$ cano (Chile) revealed by annually laminated lake sediments. GSA Bulletin 126 (:-4): :81-498. doi:10.1130/b30798.1

Vogel H, Russell JM, Cahyarini SY, Bijaksana S, Wa trus N, Rethemeyer J, Melles M (2015) Depositional modes and lake-level vari $b^{b} i^{\wedge} y$ at Lake Towuti, Indonesia, during the past 29 kyr BP. Journal of Paleolimn ' log y 4 (4):359-377. doi:10.1007/s10933-0159857-z

Vogel H, Wagner B, Zanchetta G, Sulpizı R, Rosén P (2010a) A paleoclimate record with tephrochronological age cont. $>$ for the last glacial-interglacial cycle from Lake Ohrid, Albania and Macedonia siurnal of Paleolimnology 44 (1):295-310. doi:10.1007/s10933-009-94C4 x

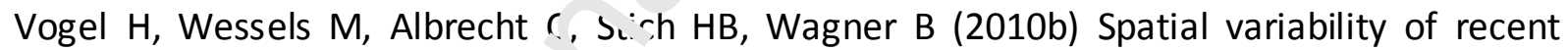
sedimentation in Lake (' hrı' (Albania/Macedonia). Biogeosciences 7 (10):3333-3342. doi:10.5194/bg-7-333, ? $\cup: 0$

Vogel H, Zanchetta G, Sur i ij R, Wagner B, Nowaczyk N (2010c) A tephrostratigraphic record for the la: $\mathrm{t}$ gl cial-interglacial cycle from Lake Ohrid, Albania and Macedonia. Journal of Quatc "nary Science 25 (3):320-338. doi:10.1002/jqs.1311

Wan SM, Toucanne S, Clif. PD, Zhao DB, Bayon G, Yu ZJ, Cai GQ, Yin XB, Revillon S, Wang DW, Li AC, Li TG (2015) Human impact overwhelms long-term climate control of weathering and erosion in southwest China. Geology 43 (5):439-442. doi:10.1130/G36570.1

Weber Y, De Jonge C, Rijpstra WIC, Hopmans EC, Stadnitskaia A, Schubert CJ, Lehmann MF, Damste JSS, Niemann H (2015) Identification and carbon isotope composition of a novel branched GDGT isomer in lake sediments: Evidence for lacustrine branched GDGT production. Geochimica Et Cosmochimica Acta 154:118-129. doi:10.1016/j.gca.2015.01.032

Weijers JWH, Schouten S, Spaargaren OC, Damste JSS (2006) Occurrence and distribution of tetraether membrane lipids in soils: Implications for the use of the TEX86 proxy and the BIT index. Organic Geochemistry 37 (12):1680-1693. doi:10.1016/j.orggeochem.2006.07.018

Weltje GJ, Bloemsma MR, Tjallingii R, Heslop D, Röhl U, Croudace IW (2015) Prediction of Geochemical Composition from XRF Core Scanner Data: A New Multivariate 
Approach Including Automatic Selection of Calibration Samples and Quantification of Uncertainties. In: Croudace IW, Rothwell RG (eds) Micro-XRF Studies of Sediment Cores: Applications of a non-destructive tool for the environmental sciences. Springer Netherlands, Dordrecht, pp 507-534. doi:10.1007/978-94-017-9849-5_21

Weltje GJ, Tjallingii R (2008) Calibration of XRF core scanners for quantitative geochemical logging of sediment cores: Theory and application. Earth and Planetary Science Letters 274 (3-4):423-438. doi:10.1016/j.epsl.2008.07.054

Wennrich V, Francke A, Dehnert A, Juschus O, Leipe T, Vogt C, Brigham-Grette J, Minyuk PS, Melles M, El'gygytgyn Science P (2013) Modern sedimentation patterns in Lake El'gygytgyn, NE Russia, derived from surface sediment and inlet streams samples. Clim Past 9 (1):135-148. doi:10.5194/cp-9-135-2013

Wennrich V, Minyuk PS, Borkhodoev V, Francke A, Ritter B, Nowaczyk NR, Sauerbrey MA, Brigham-Grette J, Melles M (2014) Pliocene to Pleistocene climate and environmental history of Lake El'gygytgyn, Far East Rus ian Arctic, based on highresolution inorganic geochemistry data. Clim Past 1C (4): :381-1399. doi:10.5194/cp10-1381-2014

White AJ, Stevens LR, Lorenzi V, Munoz SE, Lipo CP, $\subseteq$ r. $n$ f der S (2018) An evaluation of fecal stanols as indicators of population chan $_{5}$ ? at Cahokia, Illinois. Journal of Archaeological Science 93:129-134. doi:10.1C '6/j as.2018.03.009

Wilcken KM, Fujioka T, Fink D, Fulop RH, Codilean ' $T$, : :mon K, Mifsud C, Kotevski S (2019) SIRIUS Performance: Be-10, Al-26 and (.l-;, measurements at ANSTO. Nucl Instrum Meth B 455:300-304. doi:10.1016/j.ninib.<ن 19.02 .009

Wilhelm B, Sabatier P, Arnaud $F(2015$ ' Is a rional flood signal reproducible from lake sediments? Sedimentology 62 (4): - 03-1117. doi:10.1111/sed.12180

Willenbring JK, Codilean AT, McElro, B (2013) Earth is (mostly) flat: Apportionment of the flux of continental sediment ve: millennial time scales. Geology 41 (3):343-346. doi:10.1130/G33918.1

Woodward C, Shulmeister J, La seı. J, Jacobsen GE, Zawadzki A (2014) The hydrological legacy of deforesta:ior on global wetlands. Science 346 (6211):844. doi:10.1126/science.1250 10

Yin Q, Berger A (2015) Intt. : la cial analogues of the Holocene and its natural near future. Quaternary Scier :e $\mathrm{k}$ যviews 120:28-46. doi:10.1016/j.quascirev.2015.04.008

Zanchetta G, Baneschı ' riancke A, Boschi C, Regattieri E, Wagner B, Lacey JH, Leng MJ, Vogel $H$, Sadori 1 .2018) Evidence for carbon cycling in a large freshwater lake in the Balkans over the last 0.5 million years using the isotopic composition of bulk organic matter. Quaternary Science 202:154-165. doi:10.1016/j.quascirev.2018.10.022

Zell C, Kim JH, Dorhout D, Baas M, Damste JSS (2015) Sources and distributions of branched tetraether lipids and crenarchaeol along the Portuguese continental margin: Implications for the BIT index. Cont Shelf Res 96:34-44. doi:10.1016/j.csr.2015.01.006

Zolitschka B (1998) A 14,000 year sediment yield record from western Germany based on annually laminated lake sediments. Geomorphology 22 (1):1-17. doi:10.1016/S0169555X(97)00051-2 


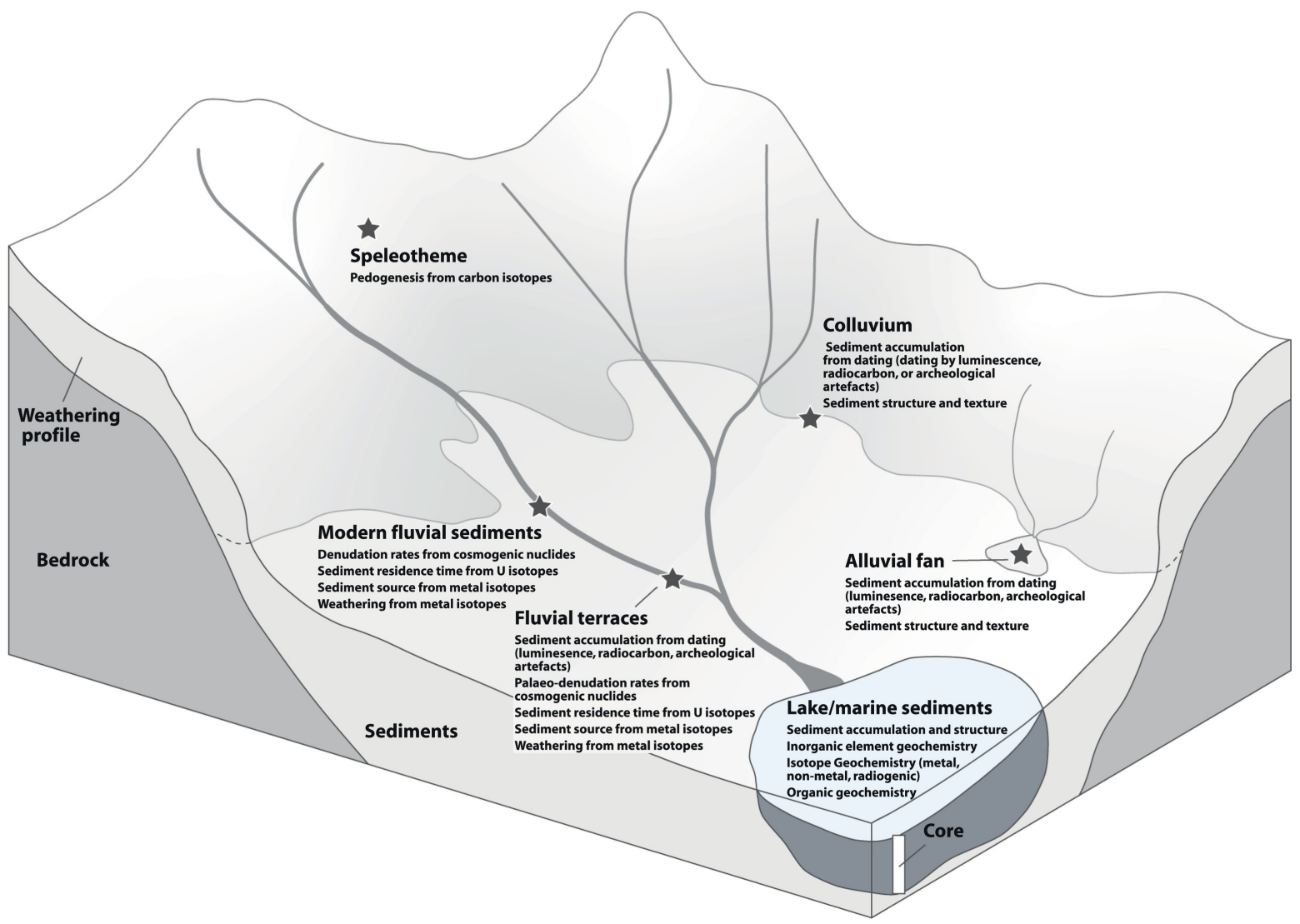

Figure 1 


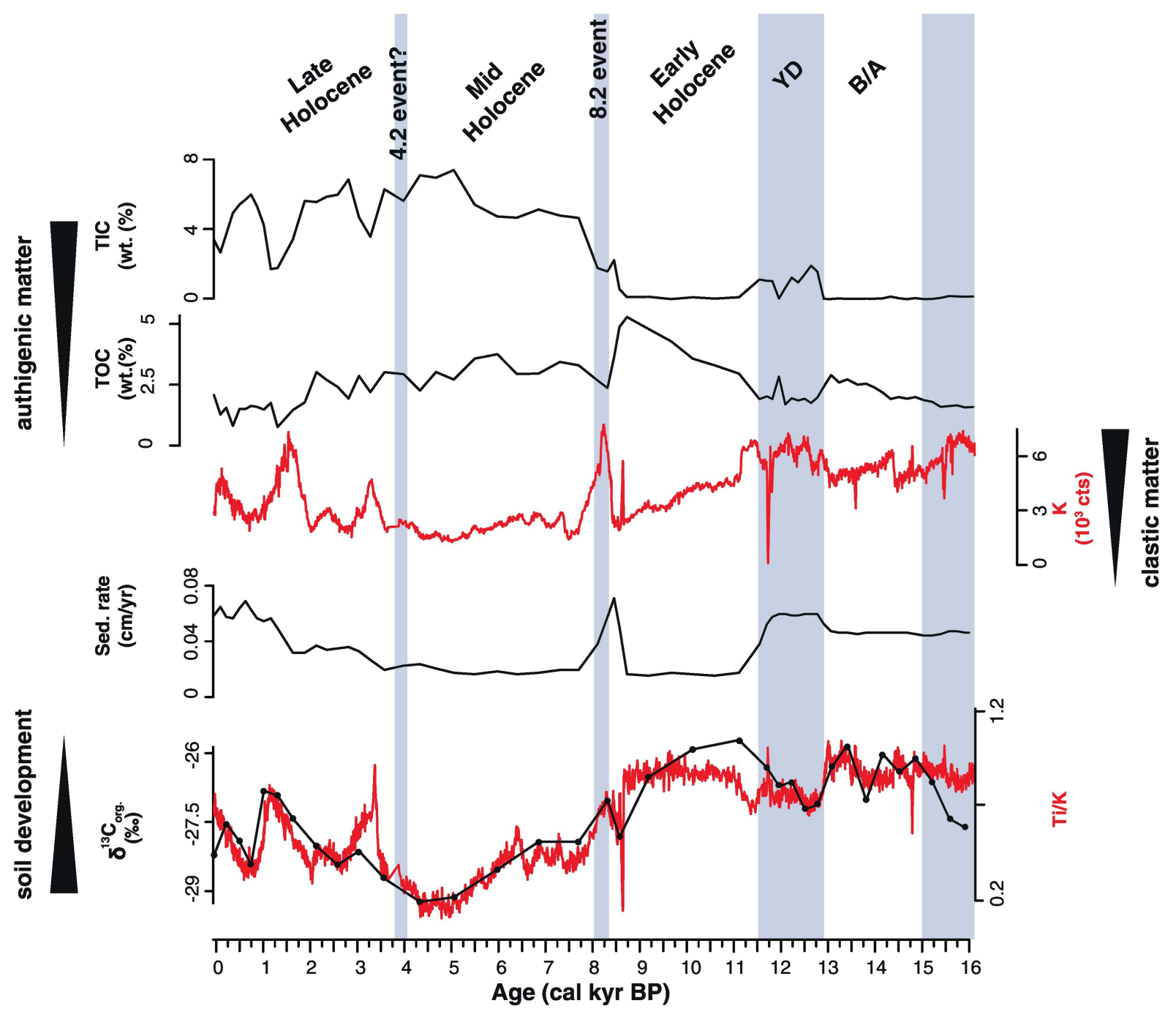

Figure 2 


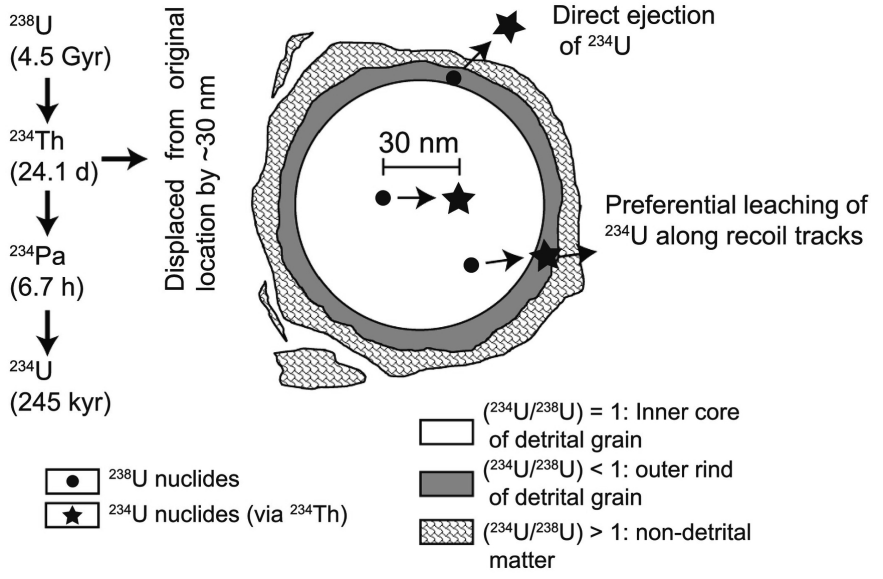

Figure 3 


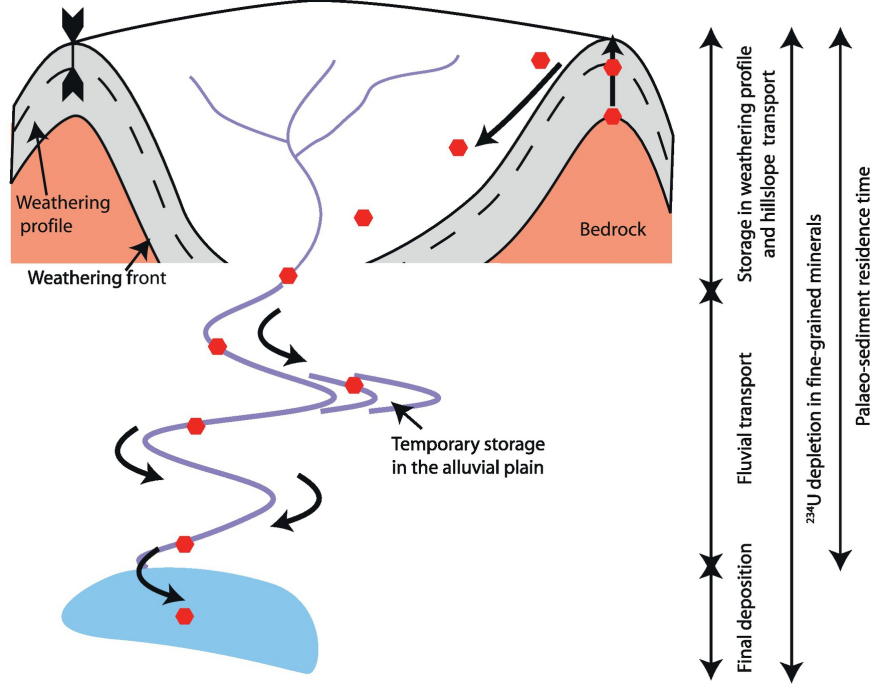

Figure 4 


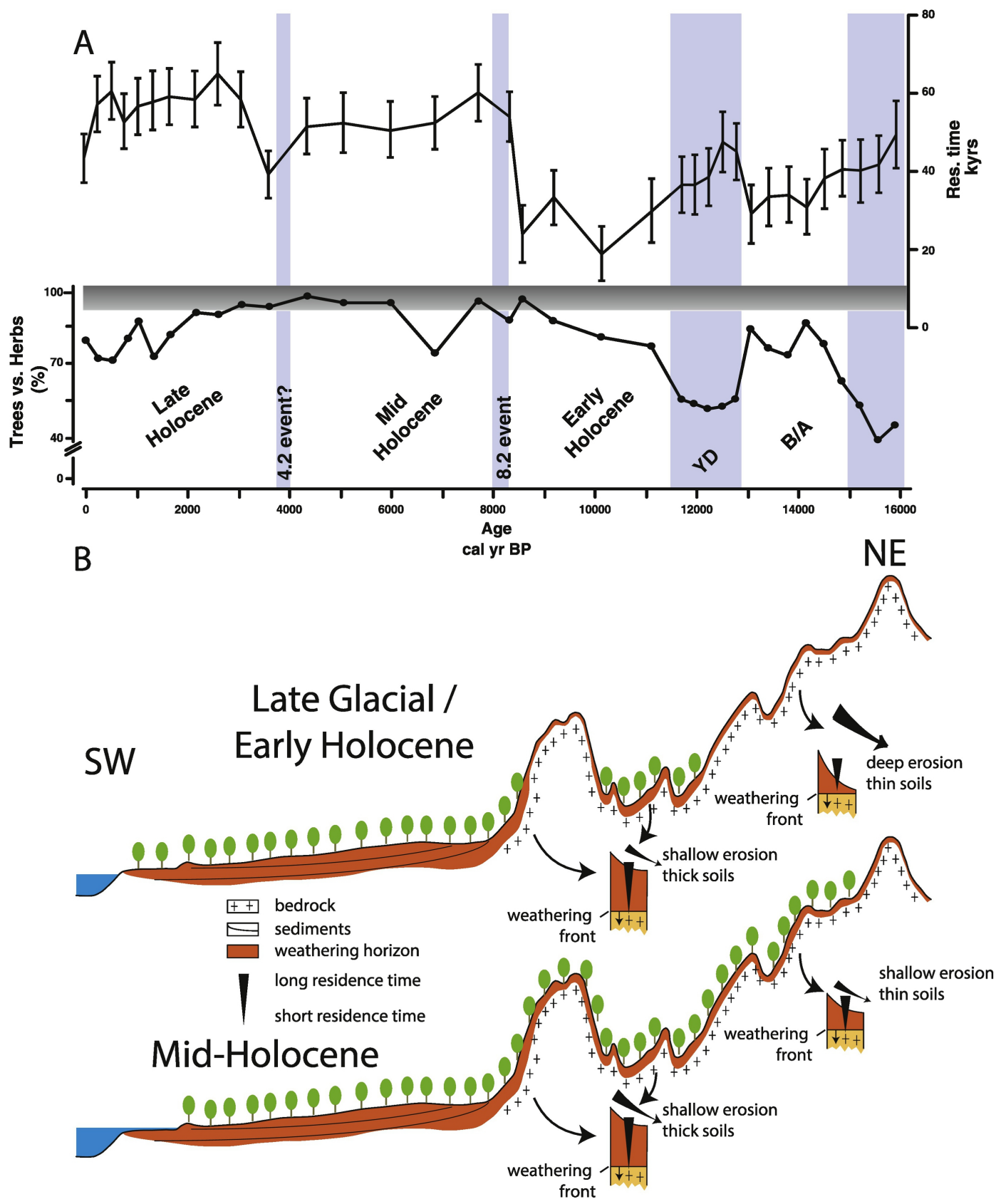

Figure 5 


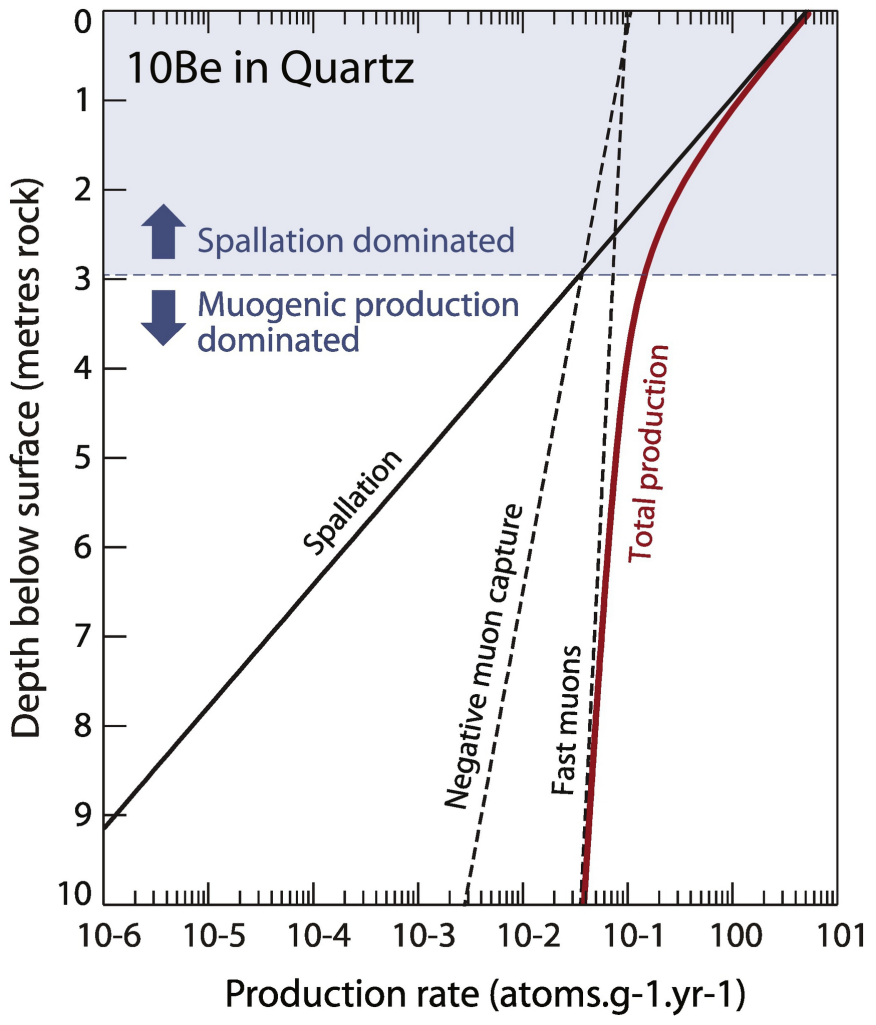

Figure 6 

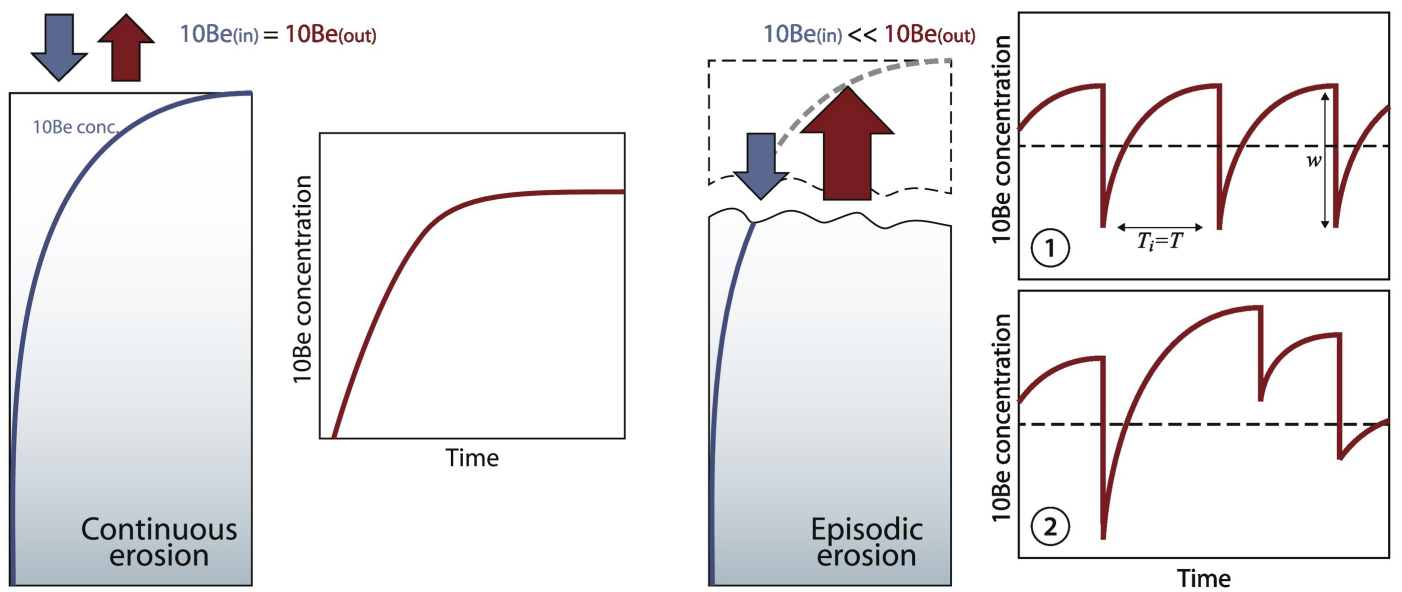

Figure 7 


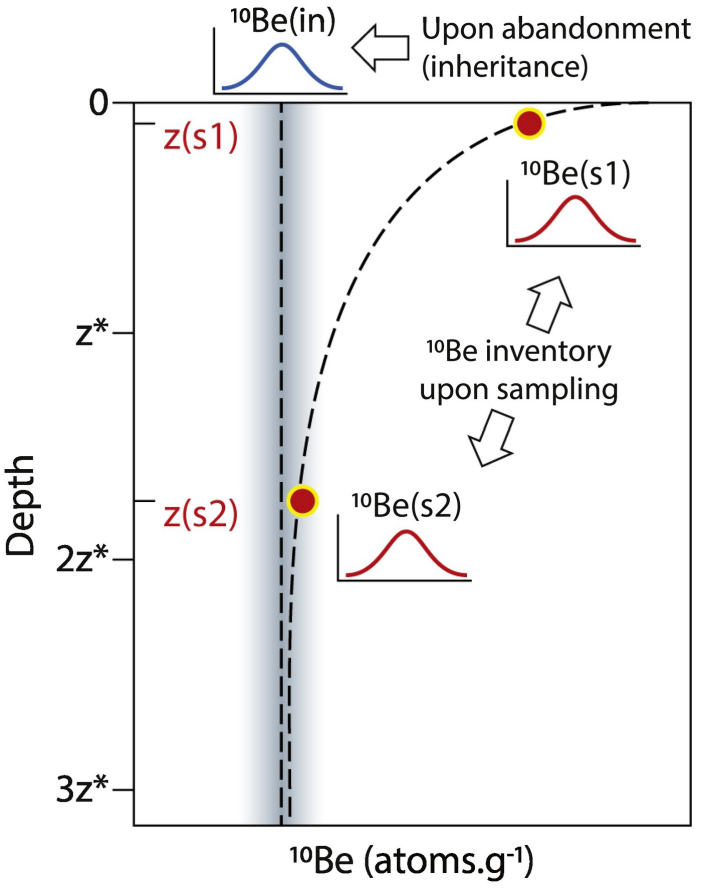

Figure 8 

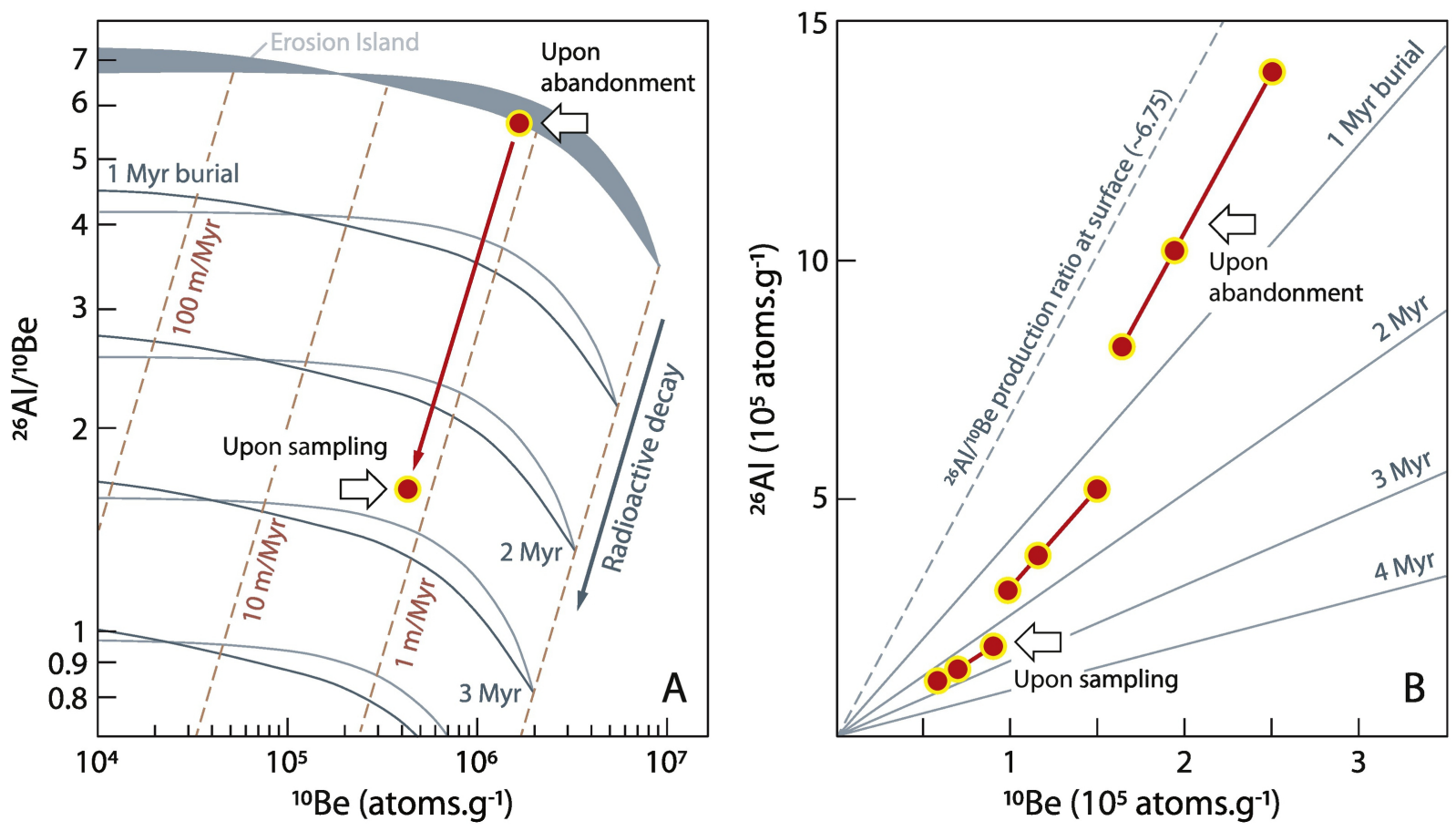

Figure 9 
$n$-fatty acids

16
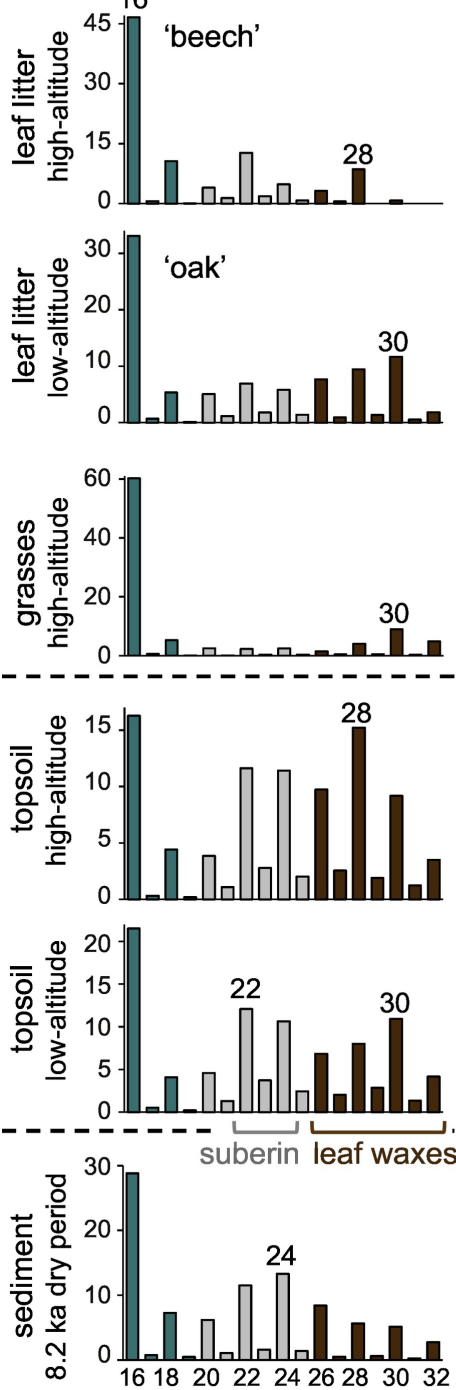

n-alkanes
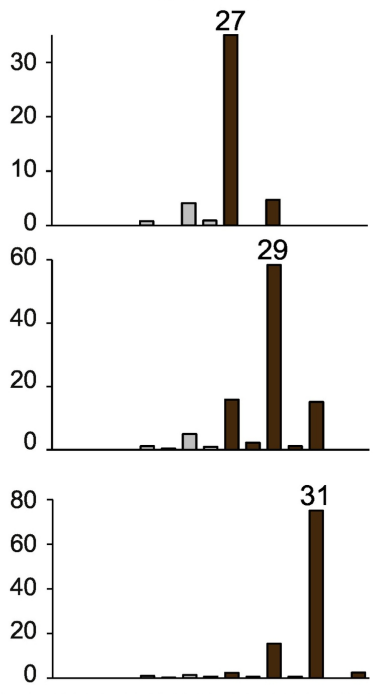

31
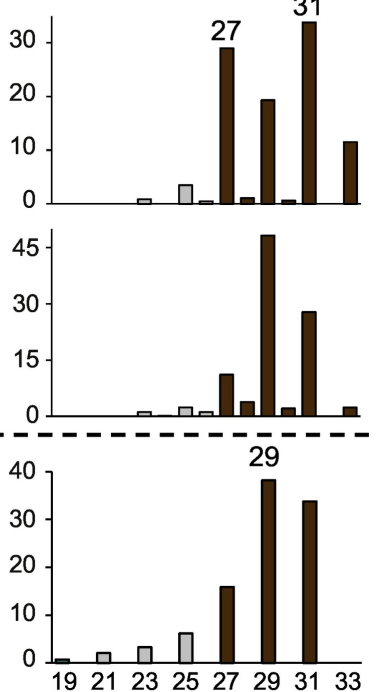

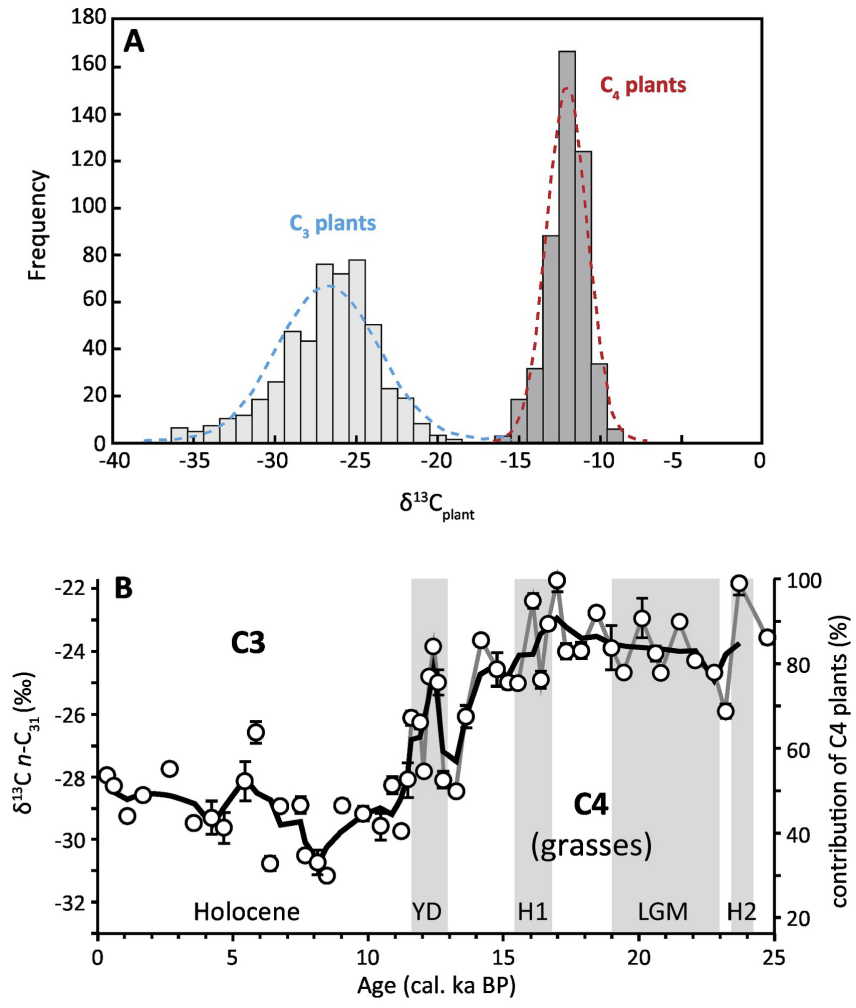

Figure 11 